\title{
The Impact of Religion on Minority Identity and Community: A Case Study of Russian Orthodoxy and the Russian Minority in Estonia
}

Elizabeth Cleary

Follow this and additional works at: https://researchrepository.wvu.edu/etd

\section{Recommended Citation}

Cleary, Elizabeth, "The Impact of Religion on Minority Identity and Community: A Case Study of Russian Orthodoxy and the Russian Minority in Estonia" (2014). Graduate Theses, Dissertations, and Problem Reports. 5372.

https://researchrepository.wvu.edu/etd/5372

This Thesis is protected by copyright and/or related rights. It has been brought to you by the The Research Repository @ WVU with permission from the rights-holder(s). You are free to use this Thesis in any way that is permitted by the copyright and related rights legislation that applies to your use. For other uses you must obtain permission from the rights-holder(s) directly, unless additional rights are indicated by a Creative Commons license in the record and/ or on the work itself. This Thesis has been accepted for inclusion in WVU Graduate Theses, Dissertations, and Problem Reports collection by an authorized administrator of The Research Repository @ WVU. For more information, please contact researchrepository@mail.wvu.edu. 
The Impact of Religion on Minority Identity and Community: A Case Study of Russian Orthodoxy and the Russian Minority in Estonia

\title{
Elizabeth Cleary
}

Thesis submitted to the Eberly College of Arts and Sciences at West Virginia University

In partial fulfillment of the requirements for the degree of Master of Arts in History

\author{
Robert Blobaum, Ph.D., Chair \\ Joshua Arthurs, Ph.D. \\ Joseph Hodge, Ph.D.
}

Department of History

Morgantown, West Virginia

2014

Keywords: Orthodoxy, Estonia, Russia, Russian Orthodox Church, minority, identity, integration, religion 


\begin{abstract}
The Impact of Religion on Minority Identity and Community: A Case Study of Russian Orthodoxy and the Russian Minority in Estonia

Elizabeth Cleary
\end{abstract}

Minority groups and their integration and inclusion into the greater society are important political and sociological concerns for many states. This is especially true for the states that more recently regained their independence following the dissolution of the Soviet Union. The realm of religion has remained largely untapped as an area in which minority identity can be cultivated and expressed or used as a platform towards productively integrating or isolating minority members.

This thesis seeks to contribute to the scholarship on this underdeveloped topic of how religion, minority identity, and issues of integration intersect. Its key questions are a) whether religion significantly fosters identity within minority groups, b) whether religious communities linked with specific minority groups help or hinder integration, and c) what level of importance religion has in the interplay of minority identity and loyalty to the state where a minority has long resided or claims citizenship. To answer these questions, the case study of Estonia was chosen. Not only does its large Russian minority, history as a former Soviet republic, and proximity to Russia make it a fitting choice for this topic, but its religious landscape provides an interesting field for examination. Home to two Orthodox churches (the Estonian Orthodox Church-Moscow Patriarchate and the Estonian Apostolic Orthodox Church) under two competing patriarchates (Moscow Patriarchate and Ecumenical Patriarchate of Constantinople), the churches have the potential to be alternative platforms through which ethnic-specific concerns and views are expressed and embodied.

In order to answer the key questions of this study, statistical sources have been analyzed, providing both a quantitative picture of both the minority and the religious composition of Estonia. Those numbers were enlivened with a qualitative look at minority issues, national historical narratives, and religious community relationships that still contribute greatly to the dialogue in Estonia today. Interviews with Estonian clergy, academics, nonprofit leaders, and government employees form a significant part of this research and are an important element of its contribution to current scholarly debates. Through this variety of research and sources, I argue that Estonia, even in light of its nonreligious reputation, does contain Orthodox religious communities that effect identity, both in terms of directly participating members in Orthodox church services and those who claim to be Orthodox but are not religiously active. The Orthodox churches provide a connection to ethnic and national loyalties and identities, inevitably becoming politically charged and thus making the churches occasional participants in the debates of large minority issues, especially those that implicate the involvement of the neighboring Russian Federation. Churches, especially the Orthodox communities of Estonia, have the potential to be leaders in resolution, compromise, and cooperation among Estonians and Russians, but must be cultivated as such or risk being case into the role of entities of future division. 


\section{Table of Contents}

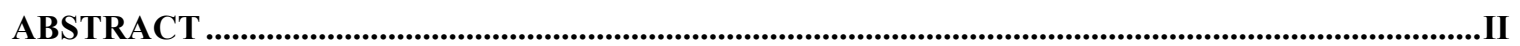

TABLE OF CONTENTS................................................................................................................. III

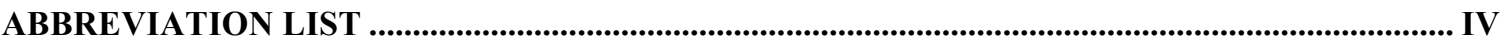

INTRODUCTION ......................................................................................................................................

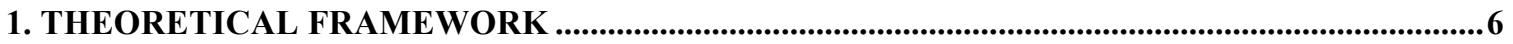

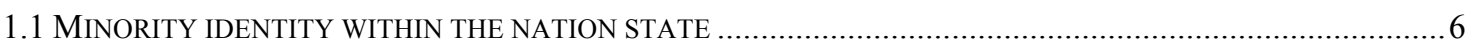

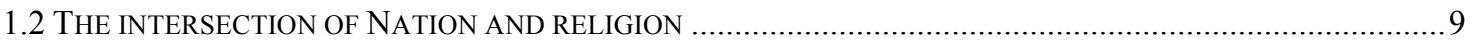

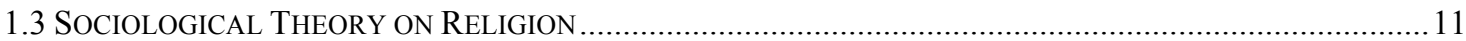

2. HISTORICAL OVERVIEW ....................................................................................................................15

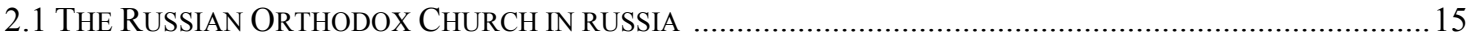

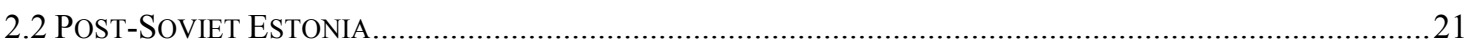

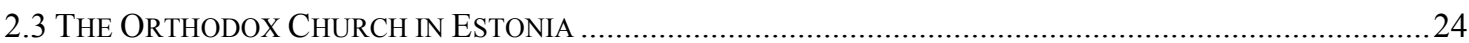

2.3.1 The Conflict Between the Estonian Apostolic Orthodox Church and the Estonian Orthodox

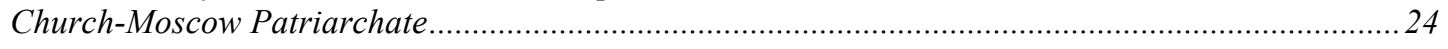

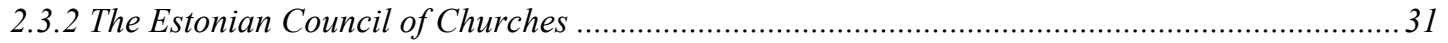

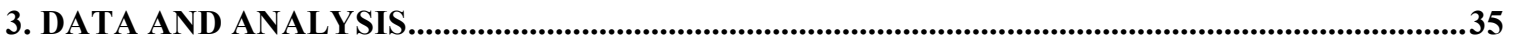

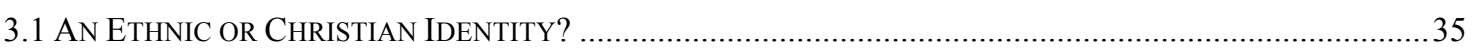

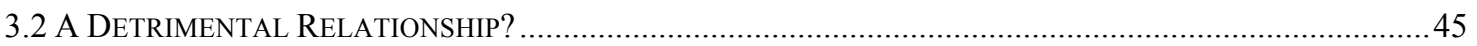

3.3 ReLigion AS A TOOL Of Political MobiLization ........................................................................ 48

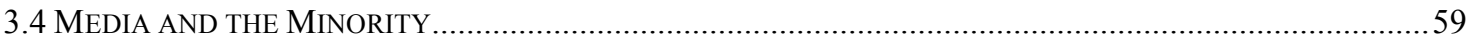

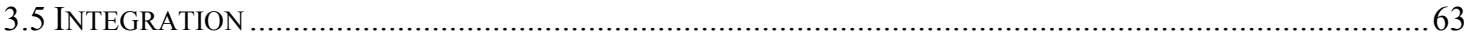

3.5.1 Culture

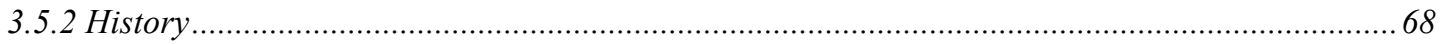

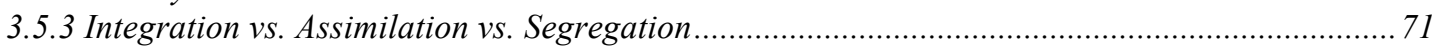

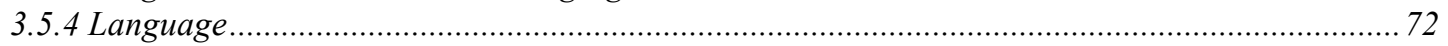

4. THE UKRAINIAN CRISIS AND ITS POSSIBLE IMPLICATIONS.................................................77

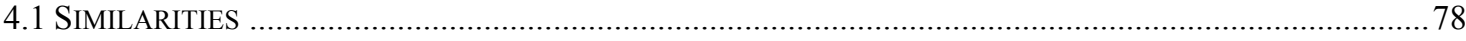

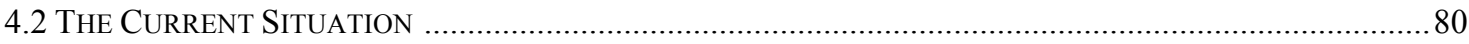

4.3 What Does This MeAn For Estonia AND the COUNTRY’s Russian MinORITY? ............................83

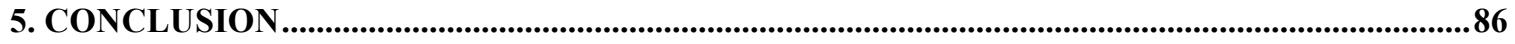

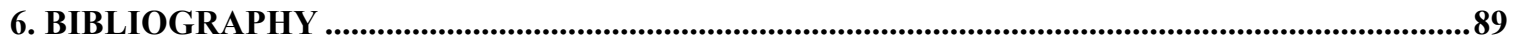

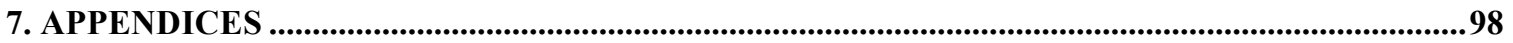




\author{
Abbreviation List \\ EAOC - Estonian Apostolic Orthodox Church \\ ECC - Estonian Council of Churches \\ EOC-MP - Estonian Orthodox Church-Moscow Patriarchate \\ EUU- "Elust, usust ja usuelust" surveys (which translates to Life, Religion, and Religious \\ Life) \\ PBK - Первый Балтийский Канал/First Baltic Channel \\ ROC - Russian Orthodox Church \\ UOAC - Ukrainian Orthodox Autocephalous Church \\ UOC-KP - Ukrainian Orthodox Church-Kiev Patriarchate \\ UOC-MP - Ukrainian Orthodox Church-Moscow Patriarchate \\ USSR - Union of Soviet Socialist Republics
}




\section{Introduction}

With the dissolution of the Soviet Union came the rebirth of sovereign Central and Eastern European states, as well as the reemergence of various institutions and freedoms that had once been forbidden by the state. From within this new openness afforded by independence grew conceptualizations of national identity that had formerly been silenced under the facade of Soviet brotherhood. Oftentimes, these identities expressed their newfound voices through the newly manifested political avenues. These voices did not only belong to the titular national cultures of these now independent states. Rather, these new states came saddled with their own identity issues, minority populations, and the unfamiliar challenge of accounting for and guiding all citizens along a unified path of constitutional democratic development.

National and ethnic identity has clearly remained at the forefront of the political discourse, especially regarding minority groups. Its importance in the political sphere rests on its role as a primary element in determining and implementing effective integration policy. It is thus important to understand the ways in which minority groups cultivate and preserve their identities; this can lead to increasingly well-informed integration policy as well as a greater understanding of minority groups' acceptance of or opposition to attempts to integrate them into the larger polity and society.

Of the former Soviet republics, Estonia provides a particularly interesting and worthwhile case study. Estonia boasts a sizeable ethnic Russian minority, a quarter of its total population of approximately 1.3 million. ${ }^{1}$ Since regaining their independence from the Soviet Union in 1991, the Estonian state has addressed this population explicitly through various avenues. Chiefly, Estonia's main strategy in terms of minority integration has centered on language. Stemming from the key concern of increasing Estonian fluency among the Russian-speaking population, the major debates regarding minority policy have targeted the importance of language in education, media, and meeting citizenship requirements. These areas are the main stages on which Estonian and Russian interests and individuals collide, naturally provoking a conflict as each group aims to strengthen or

\footnotetext{
${ }^{1}$ Statistics Estonia, http://www.stat.ee/population-census
} 
preserve their identities within a shared Estonian state. However, there remains one key point of intersection between these two groups that remains relatively under-examined and that is religion.

Religion is simultaneously one of the world's most divisive and unifying markers of identity. Much scholarship already exists on the overlap of religion and identity, the relationship between religion and the state, as well as case studies of specific religious groups and their political agendas. However, in the realm of minority politics, specifically regarding groups from areas of the world other than the Middle East, the role of religion has only been given a cursory glance thus far. This thesis aims to look at the question of whether religion creates a space in which a minority community can foster its identity and further goals specific to that minority and closely tied with the identity that they choose to express. To clarify, though this study expects to find whether religion creates this space, it is not presumed that something of a non-religious nature is not capable of doing the same thing, nor that it cannot do so simultaneously in tandem with religion. The key problems that must be solved through this research are a) to determine whether religion fosters identity within minority groups in a significant way, b) to analyze whether religious communities linked with minority groups help or hinder their integration into society as desired by the state, and c) ultimately to access the level of importance religion has in the overarching conversation of melding minority identity with civic loyalty to the state.

In pursuing this larger goal, it was important to determine a relevant case study for this research. Estonia provides a fitting choice as its minority population and the conflicts and issues that come with it have found themselves at the forefront of Estonian politics and public debate. Though Estonia identifies itself as one of the most nonreligious countries in the world, its religious communities have already been influenced by and pulled into the dialogue and disputes between Estonians and Russians. ${ }^{2}$ Russians are typically assumed to be Russian Orthodox, a Christian denomination often referred to as synonymous with calling oneself Russian. Within Estonia, the Estonian Orthodox Church of the Moscow

2 Ringo Ringvee, "Is Estonia really the least religious country in the world?," The Guardian, September 16, 2011, accessed August 25, 2014, http://www.theguardian.com/commentisfree/belief/2011/sep/16/estonialeast-religious-country-world. 
Patriarchate is not the sole Orthodox Church, but begrudgingly shares this canonical territory with the Ecumenical Patriarchate's Estonian Apostolic Orthodox Church. Therefore, the choice of this case study is grounded not only in issues of minority politics, but also in the unique and ethnically significant religious communities that call Estonia home. To use this case study effectively, an understanding of the history of the Estonian state and of these key faith communities within the country are paramount. In addition to pertinent history, analysis of statistical and survey data, conducted and compiled by the Estonian state, third party companies, and NGOs, will comprise a portion of this thesis's sources. The Elust, usust ja usuelust surveys conducted by the Estonian Council of Churches, Integration Monitoring Survey reports, and Estonian national censuses form the central base of these sources. However, when examining such broadly defined categories as religion and identity, the aims of this thesis cannot be realized solely through quantitative methods. Therefore, material collected from interviews with six experts in Estonia will contribute new material to accompany the historical, theoretical, and statistical research components of this thesis.

In evaluating the abovementioned data, their limitations must be acknowledged. Being neither a native Russian or Estonian speaker, I have had to rely on sources and interviewees that can deliver their arguments in English. Smaller, more easily translatable forays have been made into Estonian and Russian sources where possible. While this does limit the scope of the thesis, impressively high English fluency in Estonia and copious English translations of government documents and records reduce this disadvantage. Also, as interviews formed a key component of this thesis's research base, their personal and subjective nature must be recognized. As community leaders and experts in their fields, interviewees' positions undoubtedly affected the information they chose to divulge and the extent to which they were able to do so. Once again, as none of the interviewees were native English speakers, the depth or clarity of these conversations was occasionally affected.

This thesis is divided into five parts. The first section will provide a theoretical framework for understanding how this complicated intersection of religion and minority identity has been viewed thus far and how it will be defined and interpreted through this 
particular study. As the specific relationship between Estonia's Orthodox churches and the Russian minority remains a largely unexamined topic, prominent themes from the body of scholarly literature on nationalism, religion, and minority identification will be identified here. These sources and the theories and ways of thinking that they contribute form a firm foundation on which to discuss the more recent findings of Estonia's case and the original interviews conducted for this thesis. The second section will present the historical analysis, not only of Estonia's post-Soviet independent statehood and the minority issues that followed, but relationships between the two Orthodox churches and the political links they have fostered. The third section will focus on the analysis and extrapolation of statistical data in conjunction with the information gleaned from interviews, in order to create a fuller picture of identity and religion within Estonia's ethnic Russian minority. The fourth section will look at Ukraine, a topical issue at the time of this thesis's research and composition. This section first compares the similarities between its multifaceted Orthodox culture with that of Estonia's and then explores how the current situation and its effect on the Orthodox churches relationship with their patriarch could have implications for the Estonian Orthodox politics in the future. This section does not aspire to be a second in-depth case study, but simply reflects the frequent mentions of the Ukrainian conflict that arose in interviews while simultaneously positing potential future scenarios. The fifth and final section will put forth the final conclusions of this thesis.

Ultimately, this thesis, though focusing on a specific case study in Eastern Europe, has the potential to provide a greater understanding of how minorities can maintain and strengthen ties with a mother country through religion. It also may reveal whether faith has the power to link minorities to an element of their culture in such a way that it provides a stronger bond with their former or ancestral homeland over that of their country of residence. An understanding of religion's place in minority identity and communitybuilding helps push the borders of transnational thinking, a vital necessity in an increasingly globalized world. As Peggy Levitt points out, understanding the ways in which foreign-born nationals, immigrants, or non-native speakers claim their faith traditions and communities can oftentimes lead to a greater understanding of the way and intensity with which they claim a national identity. Today's churches play a different role 
than they once did when it comes to incorporating minority members into society. ${ }^{3}$ They have the potential to both cultivate cultural preservation while also isolating members or raising the suspicions of those outside of its community. Their influence and the reverberations of their actions can also be felt beyond the nation's physical borders, not only affected by politics, but in turn influencing them as well. In navigating this complex terrain, Levitt states that political overlap is inevitable. This thesis moves forward in agreement with this belief. Therefore, the questions and findings of this thesis have the capacity to not only illuminate this specific Estonian situation, but to speak to larger international religious and political themes and church-state dynamics.

${ }^{3}$ Peggy Levitt, "Redefining the Boundaries of Belonging: The Transnationalization of Religious Life," in Everyday Religion: Observing Modern Religious Lives, ed. Nancy T. Ammerman (Oxford: Oxford University Press, 2007), 103-120. 


\section{Theoretical Overview}

Identity and religion are concepts often hard to define. The words themselves are subject to numerous definitions. Additionally, this specific case study of Estonia is unique, as it brings together elements, such as nationalism, religious belief and fervor, borders, minorities, and ethnic heritage, which are typically studied separately or with minimal comparison. Therefore, this section will introduce the theories and studies that are important for the context of this thesis, providing a clearer look at the foundation on which identity and religion are understood and how they will be employed or referenced throughout the following text. The subsections of this chapter explore first the issues of the nation, looking at Rogers Brubaker's influential reordering of the concept of nationalism and the nation and how shifting our perception of these two elements changes how we see borders and cross-cultural influences. Second, the ways in which religion and nation tie together are explored, beginning with a look at the more basic, common footing that nationalism and religion share, before expanding into the role of religion as an archive of lineage and continuity which can be used as a tool for nationalistic aims. Finally, the sociological role of religion and impactful literature on that subject are discussed, primarily centering on the theme of religion's persistent nature and the nature of its adherence today.

\subsection{Minority Identity Within the Nation State}

The considerably large Russian population within Estonia finds itself in close proximity to a land that many would recognize as a historic or more recent mother-state. Though Russian-speakers within Estonia are not always ethnically Russian, nor were they necessarily born in Russia proper, their link to a country that speaks the second most popular language in Estonia, is right across the border, and once called Estonia part of its territory factors prominently into Estonian state considerations and policy. Understanding links to a nation or nationalism that exists beyond the confines of an actual border is necessary in this instance. Rogers Brubaker's Nationalism Reframed: Nationhood and the National Question in the New Europe, looks at this very issue, pointing to the Soviet Union's dissolution specifically as one of his argument's key examples where a typical understanding of nationhood, nationalism, and the national question is challenged. 
Brubaker acknowledges that the formation of states around the "principle of nationality" was a formative shift conducted by numerous states in the wake of the Soviet Union's collapse, a purposeful secession from the multinational superpower that it had once been. ${ }^{4}$ Estonia is a fitting example of this development, as the independent post-Soviet state was and continues to be understood as distinctly Estonian, a point particularly expressed through the official state language, though equal rights and protection are afforded to other ethnic minorities in Estonia's constitution. ${ }^{5}$ Growing alongside these nations that are actively "nationalizing" are what Brubaker terms "external national homelands," nations whose nationalisms are assertive by nature, actively seeking to oppose or compete for claims over people. ${ }^{6}$ Typically, these homeland perspectives grow from defeat or dissolution, their sentiments a result of loss of status and space that hurts the nation's power, influence, prestige, and economic and political impact. They assert themselves as this "external national homeland" when they begin to view residents of neighboring countries as their co-nationals and lay claim to a responsibility for them. Russia's policy towards nationals abroad conforms remarkably well to Brubaker's classification, as evidenced in the official Concept of the Foreign Policy of the Russian Federation. ${ }^{7}$ Estonia, as an immediate neighbor and home to a significant Russian minority, fulfills the criteria to warrant Russia's politically watchful eye.

Brubaker's text posits that "nation" is something that is practiced rather than territorially institutionalized. ${ }^{8}$ Nationness ${ }^{9}$ lies with the people, rather than the territory

\footnotetext{
${ }^{4}$ Rogers Brubaker, Nationalism Reframed: Nationhood and the National Question in the New Europe (Cambridge: Cambridge University Press, 1996), 3.

${ }^{5}$ Constitution of the Republic of Estonia, chp. I, $\$ 6$.

${ }^{6}$ Brubaker, Nationalism Reframed: Nationhood and the National Question in the New Europe, 5.

${ }^{7}$ Concept of the Foreign Policy of the Russian Federation, Section 3, 39 d) and e) http:/www.mid.ru/brp_4.nsf/0/76389FEC168189ED44257B2E0039B16D

Konstantin Kosachev, "Russia must defend interests of compatriots abroad," Valdai, March 3, 2013, accessed October 20, 2013, http://valdaiclub.com/politics/56220.html.

${ }^{8}$ Brubaker, Nationalism Reframed: Nationhood and the national question in the New Europe, 21.

${ }^{9}$ Brubaker uses the term "nationness" as an instigator for thinking about the word "nation" differently. Essentially the two words are meant to be the same, but he employs "nationness" to stress the nation's role "as practical category, institutionalized form, and contingent event. 'Nation' is a category of practice, not (in the first instance) a category of analysis" (7). I use the term in the same way as Brubaker in this thesis, subscribing to his call to change the thinking surrounding the concept of nation from an established entity, "a real group," through which we evaluate participants and events to that of a changing concept that they act on and through, inviting change.
} 
though this is often confused. In fact, the Soviet Union's republics and autonomous regions contributed to this confusion, classifying territories based on the ethnic descent of its inhabitants. However, in generating these categories of social identification, the Soviets simultaneously failed to create a link between that ethnic label and citizenship, as the USSR was a self-professed multi-national union. ${ }^{10}$ This link between territory and ethnic identity helped to pave the way for countries such as Estonia to break from the conglomeration that was the Soviet Union into smaller, more ethnically homogenous states. Yet, having used such methods to secure their independence, the element of an everevolving nationness that Brubaker encourages is lost in today's discussions of transnational relations. Rather, it appears that territorial and cultural boundaries must align, while Brubaker challenges society to think of nationalism without nations, and of "national autonomy...not [as] the convergence of territorial administration and national culture, but their independence."11

Brubaker correctly predicted that nationalizing states would continue to have tense relationships with new minority groups within their borders and the states beyond their borders that these groups acknowledged as external homelands. His predictions also ring true in the case of Estonia when he states that successor states will see newly defined Russian enclaves develop within their national borders, an almost compensational occurrence considering the loss of territory from the dissolution of the Soviet Union. At the point of publication, Nationalism Reframed did not have the distance from the construction of new states that would have been necessary to predict how the former Soviet republics would deal with the portions of their citizenry that were members of a new Russian minority, nor how that minority would react to its new status. Nevertheless, Brubaker's work in redefining and contextualizing nationalism and nationness with modern historical examples remains pertinent to this thesis. Not only have many of his predictions been particularly applicable to Estonia's case, but also the questions that he poses and was unable to answer at the time of his writing remain relevant to the concerns of this thesis. His curiosity as to how minority Russians will identify themselves - as an entirely separate

\footnotetext{
${ }^{10}$ Ibid, 23

11 Ibid, 40.
} 
nationality or along lines of language and culture - and in what ways Russia itself will choose to effect or influence the extent of Russians' resoluteness in setting themselves apart will be explored in this study. ${ }^{12}$

\subsection{The intersection of nation and religion}

One cannot read Brubaker and employ his notion of "nationalization of political space" without engaging with Benedict Anderson's classic work, Imagined Communities. The concepts that Anderson puts forth are famous in the study of nationalism, and for the purposes of this thesis, serve to begin bridging the gap between the foci of nation and faith. From the beginning, Anderson compares the strength of nationalist imaginings with that of religious fervor. Just as one belongs to a nation, whose bounds and population stretches beyond one's capability to understand, a similar phenomenon can be used to explain faith communities. Anderson references religions as the propagators of sacred speech, as the institutions from which the pinnacles of thought, theology and culture stemmed. ${ }^{13}$ In this sense, they preceded the imagined, limited, and sovereign nation that is at the root of nationalism, a concept that Anderson and Brubaker alike argue is not fading away at the end of the twentieth century as many initially thought it would. Although Anderson looks to cultural roots for their role in the transition from a world that favors religion to a world that presently leans more on nationalism, religion remains important to how groups can and have contextualized their own identities in society. Understanding nationalism goes handin-hand with understanding religion in that the latter is one of the "large cultural systems that preceded it, out of which...it came into being." 14 Religion has offered human beings a way in which to understand the world around them, their place in it, and a means to make sense of their own suffering and the inevitable pitfalls of human existence. It centers man along a line of time that is unimaginably long, yet comfortingly familiar. It is this

\footnotetext{
12 Ibid, 48, 53.

${ }^{13}$ Benedict Anderson, Imagined Communities: Reflections on the Origin and Spread of Nationalism (London: Verso, 1991), 13.

${ }^{14}$ Ibid, 12.
} 
"language of continuity" and overarching connectedness that Anderson claims religion and the nation share as imagined communities. ${ }^{15}$

This same cross-over between religion and the nation is expertly illustrated in Katherine Verdery's work, The Political Lives of Dead Bodies: Reburial and Postsocialist Change, in which she covers the unique subject of reclaiming and relocating historically and culturally significant human remains, particularly in post-communist Romania, Hungary, and Yugoslavia. Echoing Brubaker's proposal that the Soviet Union's internal administrative structure based on republics and autonomous regions incidentally furthered ethnic identification, Verdery places her understanding of national identity and the relationships that take shape within the context of kinship construction. ${ }^{16}$ Within this kinship construction - recognizing or referring to oneself as a child of a motherland for example_-Verdery consequently locates nationalism as a variant of "ancestor worship," thus following Anderson's lead of linking strong national identification with attributes of religious affiliation which are almost pagan in their seemingly ancient nature. The bodies that are used as catalysts for burgeoning nationalist movements in successor states were seen as quintessential family members within the "national genealogy," physical relics that are of the utmost importance to groups hungry to project and defend a more recently developed or outnumbered identity. ${ }^{17}$

In focusing on the physical ownership and placement of human remains, Verdery shows how tangible items of cultural significance and heritage become politically charged and exponentially valuable. Reflections of this reality can be seen in Estonia's case and will be mentioned further, especially in references from interviewees regarding the present day dynamic and persisting tension over property disputes between the Estonian Apostolic Orthodox Church (EAOC) and the Estonian Orthodox Church-Moscow Patriarchate (EOCMP). Verdery writes of a similar problem regarding the Orthodox Church in Romania, a Church that found itself competing with Greek Catholics for property, government funding, and public recognition, many of the same struggles that other Orthodox congregations have

\footnotetext{
15 Ibid, 11.

${ }^{16}$ Katherine Verdery, The Political Lives of Dead Bodies: Reburial and Postsocialist Change (New York: Columbia University Press, 1999), 41.

17 Ibid.
} 
cited in the wake of socialism's collapse in various Central and Eastern European states. The desire for a restoration of popular legitimacy has been a prime motivation for the Orthodox Church's actions following communism's collapse and is not restricted to Verdery's case studies alone. ${ }^{18}$ The potential for a certain denomination or religion to be equated fully and synonymously with nationality and the patriotic influence that the church is able to exert upon individuals is a fascinating phenomenon that is certainly alive and well today. Verdery's examples of such cases show the ways in which church communities can animate themselves politically under the guise of faith, furthering ethnic-specific agendas as part of the process of nationalization. ${ }^{19}$ The use of a common heritage's physical emblems that become unexpectedly and highly charged and the furthering of the intersection of religion and nationalist politics as discussed in Verdery's work both directly influence the analysis to be made later on in this thesis.

\subsection{Sociological theory on religion}

While Anderson believes that, though influential on the foundational level, religion has been superseded by nationalism, Daniele Hervieu-Leger's Religion as a Chain of Memory points towards its resiliency, an argument that this thesis supports. Though her focus does not center on states or nationalism, her work on memory and its continuation through religious traditions speaks to religion's important role in validating and reengaging people culturally. A significant portion of her book is spent attempting to define religion and the ultimate definition that she arrives at is a helpful one in terms of this study. Once again, she harkens to religion's principal characteristic of continuity, saying that "religion is an ideological, practical, and symbolic system through which consciousness, both individual

\footnotetext{
${ }^{18}$ Ibid, 72.

${ }^{19}$ Ibid, 84. Katherine Verdery includes a long quotation from the speech of a monk who regards loyalty to the Orthodox religion as tantamount to one's Romanianess. "If you want to be a true son of Christ and of Romania, hold to the righteous faith, Orthodoxy...if not, you are no son of Christ or of the Church, and you are alien to the Romanian nation." His words illustrate the way in which the Orthodox Church can be used as an ethnic and religious identity marker. In this example, he spoke effectively against incoming protestant missionaries who were subsequently not of Romanian origins and also of the strong patriotic identity present in the people at that time. It's worth noting that similar arguments have been used in Russia as well. Also, the direction of blame can easily be reversed, in minority groups criticizing the assimilation of group members into the faith communities of the majority or titular nationality.
} 
and collective, of belonging to a particular chain of belief is constituted, maintained, developed and controlled." ${ }^{20}$ Therefore, religion legitimizes not only the faith-based beliefs and traditions, but the identity of those who call themselves members as well. This identification is dually calibrated - locating the individual within the community and locating the community apart from those who are different. ${ }^{21}$

Hervieu-Leger's text is rich with deep sociological insights, but the greatest contribution gleaned from her work for the sake of this thesis is that of the connection between memory and religion. Noting that the structure of our memories have morphed over time from one shared memory into the categorized memories that we now possess, bearing labels such as national, religious, or familial memories, Hervieu-Leger points to the importance of anamnesis, "the recalling to memory of the past...often observed as a rite" as central to the continued lineage of religious identity and practice. ${ }^{22}$ Any witness to or participant in an Orthodox liturgy would undoubtedly agree that the practice of anamnesis is alive and well within the walls of these churches and cathedrals. A full sensory experience, its sounds, smells, and sights have been praised for their evocativeness, calling believers back thousands of years while simultaneously casting them forward, as the liturgy has remained and will continue to the remain the same for ages. The chain of memory that Hervieu-Leger has highlighted in her title is embodied in the Orthodox Church. Yet, this thesis is concerned with Orthodoxy in Estonia, a country that, as previously mentioned, is typically known for its lack of religiosity. It is probably safe to assume that the Orthodox churches within Estonia, particularly those with high proportions of Russians, foster a sense of continuity and cultural remembrance. Due to the small numbers of actual church attendance however, something else must be factored in to account for the relevance of fostering identity through a faith community.

Grace Davie fills that gap with the expansive scope of her study on the sociology of religion. Having worked her way outward from a the study of religion in a region of Great Britain, to the British isles more generally, and now to Western Europe and the United

\footnotetext{
${ }^{20}$ Daniele Hervieu-Leger, Religion as a Chain of Memory, trans. Simon Lee (New Brunswick: Rutgers University Press, 2000), 82.

${ }^{21}$ Ibid, 81 .

${ }^{22}$ Ibid, 125.
} 
States, she has supplied the discourse on religion in the West with some of its key terms. Chief among these is "believing without belonging," a phrase describing European religiosity that has gained a great amount of popularity since its first introduction in her 1994 book Religion in Britain since 1945: Believing without Belonging. The concept is fairly straightforward as its wording indicates: it is the phenomenon in which there is a discrepancy between what people profess believing in and what they actually practice in the religious aspect of their lives or how often they attend church or temple. ${ }^{23}$ Its popularity spoke to the resonance it had throughout Europe when describing its religious environment. Though it is still used today quite often, newer scholarship has turned towards critiquing the accuracy of the phrase's claims and Davie herself has moved beyond it, realizing that the disconnect between believing and belonging is more complicated than a mere catchphrase.

I agree with Davie's reassessment considering that the Russian Orthodox Church has the opposite problem; statistics within Russia show that most Russians claim the title of Orthodox (belonging) without practicing the accompanying faith or adhering to the morals it imparts (believing) ${ }^{24}$ Revisiting this phenomenon, Davie crafted the concept of "vicarious religion," defined as "the notion of religion performed by an active minority but on behalf of a much larger number, who (implicitly at least) not only understand, but, quite clearly, approve of what the minority is doing. ${ }^{, 25}$ This vicariousness can take place through a variety of different forms, ${ }^{26}$ but ultimately is rooted in churches and the small number of engaged believers acting on behalf of the inactive majority. This small number is accepted culturally, welcomed on occasions by both peoples and governments where tradition or need warrants. Davie develops her concept of vicarious religion by concentrating on Western Europe, choosing as her demarcating line the split of Orthodoxy

${ }^{23}$ Grace Davie, Religion in Britain since 1945: Believing without Belonging, (Oxford: Blackwell, 1994)

${ }^{24}$ Alexey D. Krindatch, "Changing relationships between Religion, State and Society in Russia," GeoJournal 67 (2006): 277-278.

${ }^{25}$ Grace Davie, "Is Europe an Exceptional Case," The Hedgehog Review (2006): 24, accessed August 1, 2014, http://www.dnva.no/binfil/download.php?tid=39409

${ }^{26}$ Forms of vicarious religion: "churches and church leaders perform ritual on behalf of others; church leaders and churchgoers believe on behalf of others; church leaders and churchgoers embody moral codes on behalf of others; churches can offer space for the vicarious debate of unresolved issues in modern societies." Grace Davie, "Vicarious Religion: A Methodological Challenge," in Everyday Religion: Observing Modern Religious Lives, ed. Nancy T. Ammerman (Oxford: Oxford University Press, 2007), 23. 
and Roman Catholicism, a line she views as far more basic than the communist and noncommunist one that has garnered more attention in recent years. Though she forgoes exploration into the Eastern and Central European regions due to their diverse denominational preferences, she does acknowledge Estonia as a country clearly facing the West, in part due to its Lutheran tradition and in spite of its large Russian neighbor. ${ }^{27}$

Davie's avoidance of this more complex region of Europe directly speaks to the intended contributions of this thesis, which aims to further the conversation on the way in which religion can act politically and culturally in one case study for a country that falls between Russia and the greater expanse of Western Europe. The theoretical construct of vicarious religion moves one's attention beyond the numbers that are filling religious buildings on a weekly basis and looks at the way in which they preserve a collective memory, the societal role they claim and the societal role they actually fulfill, and the agency with which they can act and participate in the larger workings of the nation. ${ }^{28}$ By using Davie's framework to speak to the validity of looking at religion as an minority identity marker in such a presumably irreligious country as Estonia, I hope to show that a nation does not have to be strictly religious or secular in definition, but can be home to churches and religious communities that are sought after in unsettling times and that can minister to national communities in ways that go beyond religious doctrine. Davie's vicarious religion looks to churches as "a form of public utility," a relevant avenue to pursue in distinguishing what services this public utility performs and thus what role it plays in minority groups, their identity, and their overall representation and interaction with majoritarian communities. $^{29}$

\footnotetext{
${ }^{27}$ Grace Davie, Religion in Modern Europe: A Memory Mutates, (Oxford: Oxford University Press, 2000$), 4$.

${ }^{28}$ Chris Ducker, "Believing in Grace Davie: what does she bring to an understanding of mission in Europe?," Encounters Mission Journal 36 (2011): 4.

${ }^{29}$ Ibid, 7.
} 


\section{Historical Overview}

In conjunction with understanding the underlying themes and scholarship that influence the chosen case study, historical analysis is a necessity, as it provides the opportunity to see the abovementioned influential theories derived from social science integrated into actual events, thus rounding out the landscape of this case study. The present day complications inherent to people, religion, and politics will be in no way resolved through this historical chapter, but their interaction over time will be clarified. When dealing with the Estonian Orthodox Church under the Moscow Patriarchate and a Russian minority in Estonia, a brief look at the Russian Orthodox Church in Russia and its philosophy towards the its believers abroad is vital. The position of the Russian Orthodox Church within Russia, its role, goals, and level of influence on or subjugation to the Russian state and its political leadership, has been debated frequently in recent scholarship and these perspectives will be addressed. After a look at the Russian side of this subject, an overview of the Estonian context will follow. This will begin with a history of recovered Estonian independence and the issues that developed as former Russian-speaking residents of the Soviet Union became in many cases Russians without a country. A closer look at the split between the two Orthodox churches within Estonia, resulting in the existence of the Estonian Apostolic Orthodox Church (EAOC) and the Estonian Orthodox Church-Moscow Patriarchate (EOC-MP) within the same canonical territory, will follow. This will lead to a discussion on the two Orthodox churches' current relationship and provide greater context and foundation for the analysis that is to take place in section three of this thesis.

\subsection{The Russian Orthodox Church in Russia}

Suppressed as all religious groups were during communist rule, the Russian Orthodox Church (ROC) struggled for survival within the Soviet Union as its churches were closed, priests and believers sent into the gulag system, and opportunities to minister to its faithful were confined to the walls of its dwindling parish churches. The ROC has been criticized for its compromises with the reigning atheistic government of that time and its failure to 
fully defend the faith. ${ }^{30}$ However, as Orthodoxy is centered around the liturgy itself, its most important dimension managed to remain preserved, despite the threats that plagued it. So, unbeknownst to the Communist leaders seeking to stamp out religion from the civil society of the USSR, their policies gave at least a glimmer of hope in keeping the faith alive, though stagnant in its development. ${ }^{31}$ This glimmer flickered a little brighter both during the Second World War when Stalin adopted a temporarily lenient policy towards the ROC in an attempt to bolster national morale and again at the onset of perestroika and glasnost, during which Gorbachev failed to adhere to the vehemently atheist party line of his predecessors. ${ }^{32}$

With the fall of communism came the revitalization of religion in Russia. Baptisms and other sacramental proceedings surged in number as Russians clamored to reclaim another facet of their lives that had been denied them under communism. This rush through the church doors was clearly visible by sheer numbers, but the depth of its profundity and sincerity was soon called into question. ${ }^{33}$ The reduction of the former Soviet Union's size resulted in the loss of populations that composed the bulk of the membership for nonOrthodox religions. With an even more dominant and ethnically homogenous base, the ROC was able to quickly reassert itself as Russia's historic national church. Claiming Orthodoxy became synonymous with being Russian. John and Carol Garrard found that $82 \%$ of Russians called themselves Orthodox, but only $42 \%$ of Russians also called themselves believers, leading one to the conclusion that Orthodoxy quickly morphed into a strong component of ethnic identity and national pride rather than an adherence to a path of

\footnotetext{
${ }^{30}$ Particularly condemned is the Declaration of Patriarch Sergius in August of 1927, in which he essentially adapted the church to suit the government's policy of atheism. Though often seen as a desperate effort to preserve the ROC in some form, even if an undesirable one, by believers in the West, Orthodox leadership typically condemns this decision, aligning it with apostasy.

Boris Talantov, "The Moscow Patriarchate and Sergianism," in Orthodox Christian Information Center, (1968), http://orthodoxinfo.com/ecumenism/cat_tal.aspx

31 John Garrard and Carol Garrard, Russian Orthodoxy Resurgent: Faith and Power in the New Russia, (Princeton: Princeton University Press, 2008), 8.

${ }^{32}$ Krindatch, "Changing relationships between Religion, State and Society in Russia," 271-272. Nicholas V. Riasanovsky and Mark D. Steinberg, A History of Russia Eighth Edition (New York: Oxford University Press, 2011), 618-624.

${ }^{33}$ Serge Schmemann, "Soul of Russia," National Geographic (2009): accessed August 28, 2014, http://ngm.nationalgeographic.com/2009/04/orthodox/schmemann-text/1
} 
Christian discipleship. ${ }^{34}$ This analysis is widely accepted by most scholars of the Orthodox Church in Russia.

Though the ROC is still lacking the authentic religious fervor from the majority of those that claim its membership, the restoration of the Church has often been seen as part of the resurrection of Russian civil society. Wallace Daniel highlights how, especially during the unsteady years of the early 1990s, the ROC was looked upon as one of the only firm institutional foundations in a nation that stood on shaky, uncertain legs. Yeltsin helped to pave the way for the acceptance of the ROC as the government's institutionalized religious partner, including the approval of the controversial and underhandedly discriminatory 1997 law "On Freedom of Conscience and on Religious Associations." 35 This document set the tone in recognizing the ROC as the most favored church in the eyes of the Russian state. It divides faith communities into three tiers of categories by which communities are classified once officially registered with the state. Each category comes with its own corresponding privileges; the ROC is coincidentally the only religious association that fulfills the criteria for the highest tier. Furthermore, Putin's unexpected rise to power was paralleled by the ROC's own rise in prominence, prestige, and interest in political involvement. ${ }^{36}$ Putin's aim to strengthen the state politically and economically was closely tied to mobilizing the Russian people behind the state by creating a greater sense of civil society and a more trusting interface between the two realms. For this, Putin turned to the ROC, an institution that that had already begun establishing a strong church-state relationship since the dissolution of the USSR and also marked the beginning of his presidency by overseeing the inauguration festivities. ${ }^{37}$ The continued presence and privileged position of the ROC in Russian governmental affairs and ceremonies to this day leaves little doubt as to which church ranks as the most influential and esteemed within the present Russian hierarchy. Though Christian belief is largely expressed by word rather than deed, the ROC has contributed greatly to the reclaiming and redefining of Russian identity following the fall of

\footnotetext{
${ }^{34}$ Garrard and Garrard, Russian Orthodoxy Resurgent, 245.

${ }^{35}$ On Freedom of Conscience and Religious Associations, October 1, 1997. http://www2.stetson.edu/ psteeves/relnews/freedomofconscienceeng.html.

${ }^{36}$ Wallace L. Daniel, The Orthodox Church and Civil Society in Russia, (College Station: Texas A\&M University Press, 2006), 70-71.

${ }^{37}$ Ibid, 73.
} 
the Soviet Union. Its nationally narrow focus for such a multi-ethnic and multi-confessional country is clearly problematic, but the strong role of the ROC at the start of the post-Soviet period and its continued presence in that position is a significant point to consider as one approaches speculation about Russians beyond the borders of the motherland.

The close ties that bind the ROC to the Kremlin have led to debates about which of the two has the upper-hand in the relationship. Zoe Knox, a historian of religion in $20^{\text {th }}$ century Russia, reintroduced the paradigm connected to the old Byzantine practice of the symphonic idea or symphonia, an idealistic design of church-state relations in which the two are seamlessly aligned with no differentiation between their policy. ${ }^{38}$ In terms of governance, symphonia differs slightly from a theocracy. The latter is a system of government in which the religious leaders are the rulers, while the concept Knox elaborates on is a close collaboration and understanding of shared goals and perspectives by the leading faith hierarchy and the political leadership. Symphonia ultimately results in the abolition of true civil society, as it eliminates the democratic concept of freedom of religion and permits one religion or church to establish a monopoly within the state, leading to religious and political agendas that are completely interwoven. ${ }^{39}$ Knox does not go so far as to claim that the ROC has obtained or will ever obtain that kind of status, but asserts that the attractiveness of this configuration of old still pulls the ROC to cooperate with the Kremlin's desires more readily in return for favored status. The more conservative, nationalistic turn in Russia's politics favors the Patriarchate's own conservative leanings, allowing the ROC to easily take on the role of "principal norm-setter." 40 Through the utilization of Orthodox affiliation and labeling in the nationalist-leaning movements within Russia seek to legitimize their Russianness through a connection with one of its foremost institutions. As that nationalism has emerged in more radical forms, particularly during the formative years of Patriarch Alexy's leadership, his unwillingness to harshly condemn acts of aggression and intolerance toward "others" stands as an example in which the ROC

\footnotetext{
${ }^{38}$ Zoe Knox, “The Symphonic Ideal: The Moscow Patriarchate's Post-Soviet Leadership,” Europe-Asia Studies 55, 4 (2003): 576.

${ }^{39}$ Ibid, 577.

40 Dmitry Trenin, “Orthodox Diplomacy,” Carnegie Moscow Center Eurasia Outlook (2013): accessed October 20, 2013, http://valdaiclub.com/politics/60920.html
} 
appeared to be deferring to the power of the state. Alexy's feeble response to divisive nationalist rhetoric is often credited to his fear of defection by certain groups within the ROC to the Ecumenical Patriarch. ${ }^{41}$ A loss in the number of adherents could result in declining influence on people's lives, which in turn would most likely disrupt the existing synergy between church and state.

However, there is also evidence indicating that the ROC possesses much more agency and acts on its own interests than merely being a puppet of the state. Though Patriarch Alexy's policy toward the state may seem weak and inconsistent, his expert political maneuvering, opportune decision-making, and willingness to strategically compromise has been credited with securing victories for the ROC, both in the sphere of politics and faith life and ultimately led some scholars to label him as a defender of the faith. ${ }^{42}$ By contrast, Patriarch Kirill's 2012 endorsement of Putin as a "miracle from God" has dramatically cast into doubt the sincerity of professed adherence to the very separation of church and state within Russia. ${ }^{43}$ However, Katja Richters looks at such recent political acts and statements by the ROC and still sees a church driven by its own religious agenda "which it has formulated independently of the state and which it seeks to implement by all available means," even if that means working particularly close with the political leadership of the Russian state. $^{44}$ In her view, the administrations of Putin and Medvedev and the ROC shared similar views on the historical narrative of the Soviet Union, thereby creating greater opportunities for overlap and mutual understanding for moving forward. Just as Putin's administration has been marked by a clear desire to best the West, so too has the Moscow Patriarchate asserted a competitive dimension in pursuing its goals.

In particular, according to Richters, "they [ROC] have revived their ancient competition with the Ecumenical Patriarchate for the position of first amongst equals in

\footnotetext{
${ }^{41}$ Zoe Knox, "Russian Orthodoxy, Russian Nationalism, and Patriarch Aleksii II,” Nationalities Papers 33, 4 (2005): 540 .

${ }^{42}$ Garrard and Garrard, Russian Orthodoxy Resurgent, 242.

${ }^{43}$ Marc Bennetts, "In Putin's Russia, little separation between church and state," Washington Times, August 13, 2012 accessed August 28, 2014, http:/www.washingtontimes.com/news/2012/aug/13/putin-russia-littleseparation-church-state/?page $=$ all

${ }^{44}$ Katja Richters, The Post-Soviet Russian Orthodox Church: Politics, Culture and Greater Russia, (New York: Routledge, 2013), 8.
} 
worldwide Orthodoxy." ${ }^{45}$ After the conquering of Constantinople in 1453 by Ottoman Empire forces, the center of Orthodox leadership was symbolically transferred to Muscovy. The most famous declaration of this comes from the writings of a monk named Filofei who claimed that "two Romes have fallen," indicating the schism that separated the church from the Pope in Rome and now the fall of Constantinople. "The third stands. And there shall be no fourth," Filofei indicated, looking to Muscovy as the new head of the eastern church. ${ }^{46}$ The state of occupation in Constantinople and the eternity of Moscow's Third Rome status all elevated the Russian hierarchy to a perceived leading status within the Eastern rite, despite the fact that the Ecumenical Patriarchate still bears the official title of "first among equals." Bartholomew, the current leader of the patriarchate located in the fallen "second Rome" rules from the heart of history, the center of the former Byzantine Empire, "but his local church has only 3,000 members and Turkey keeps tight limits on it."47 The Ecumenical Patriarch's decline of his own flock and freedoms in his home territory and the ROC's fascination with their "Third Rome" title provoke different responses from the two leading Orthodox heads. The ROC aims to keep its place of prominence while the Ecumenical Patriarchate strives to gather other Orthodox churches under its leadership to compensate for its small numbers and influence at home. Additionally, the Ecumenical Patriarchate's willingness to reach beyond its borders directly contradicts with the ROC's fixation on maintaining their strong, regional power. This difference in perspective regarding one potential territory, as well as the favorable interpretation of the Third Rome narrative by the ROC, puts these two Patriarchates in conflict, rather than collaboration. This is directly relevant to Estonia where the Ecumenical Patriarchate claims the parishes belonging to the EAOC as its canonical territory. This knowledge, in addition to the clear connection between the ROC and nationalistic groups within Russia, begs the question

\footnotetext{
45 Ibid

46 Irina Papkova, “Saving the Third Rome: 'Fall of the Empire,' Byzantium and Putin's Russia in Reconciling the Irreconcilable, ed. I. Papkova. (Vienna: IWM Junior Visiting Fellows' Conferences) Vol. 24, 2009.

47 Tom Heneghan, "Russian church the absent player at pope-patriarch summit," Reuters, May 19, 2014, accessed November 28, 2014, http://www.reuters.com/article/2014/05/19/us-pope-holyland-russiaidUSKBN0DZ13B20140519.
} 
whether these strong nation-centered ties exerted through the Church in Russia apply in its parishes beyond Russia's border as well.

\subsection{Post-Soviet Estonia}

As the Soviet Union showed itself to be clearly weakening in the 1980s, a renewed movement for Estonian independence began to gain support and momentum. Despite years of Soviet rule, propaganda and indoctrination, the younger generations recognized the uncharacteristic lack of bite being shown by Soviet forces and leadership in various East European satellite states and began to speak openly about dangers to the Estonian language and culture that many feared to be on the verge of extinction after years of deportations, labor migration and Russification. As Estonian nationalism stirred in generations that had never known anything but Soviet rule, leaders in the USSR recognized the necessity of loosening the strictures in an attempt to prevent an explosive revolt. As expected, with the opening of these release valves for public expression, there arose calls for economic autonomy and the creation of the Estonian Heritage Society, which elicited negative responses from Soviet authorities. ${ }^{48}$ Furthering the movement toward independence were the Night Song Festival in Tallinn in June of 1988 and the Baltic Chain that stretched through the three Baltic States in August of 1989 to protest the Ribbentrop-Molotov Pact signed 50 years earlier and which assigned them to the Soviet sphere of influence. The culmination of Estonia's move towards independence occurred on 20 August 1991 and the small Baltic country entered onto the road of self-government and independent statehood once more. $^{49}$

Estonia acquired more than just its long-sought independence. Estonians were now responsible for building a state and managing their own bureaucracy and citizenry. Within this new state were many Russian-speakers, some of whom had moved to Estonian lands to

\footnotetext{
${ }^{48}$ Mart Laar, "The Restoration of Independence in Estonia," in Estonia: Identity and Independence ed. JeanJacques Subrenat (Amsterdam: Rodopi, 2004), 227, 229. "Estonia's Return to Independence 1987-1991," Estonia.eu, accessed August 29, 2014, http://estonia.eu/about-estonia/history/estonias-return-toindependence-19871991.html. For a condensed but effective summary of the Estonia's movement towards independence from 1984 to 1991, see Mart Laar's chapter in Estonia: Identity and Independence. The author's personal experience of many of these events enriches the narrative.

${ }^{49}$ Riasanovsky and Mark D. Steinberg, A History of Russia, 625.
} 
work in Soviet factories, others who, despite their Russian mother-tongue had called Estonia home for their entire lives, as had generations before them. Now, in the wake of the collapse of the Soviet Union and the reestablishment of an independent Estonia, many of them found themselves stateless in an official sense. Estonia's move towards independence had been spurred on by cultural catalysts, such as the restored use of the blue, black, and white flag of the interwar state, the championing of Estonian heritage, and Mati Hint's articles rallying people to the defense of the Estonian language. ${ }^{50}$ This national pride played prominently into how the new government and the nation it served looked towards those who were not ethno-linguistically Estonian.

Focused intently on returning to the West, a goal that looked towards eventual European Union and NATO accession, the Estonian government had to develop an integration policy alongside criteria for citizenship. Stated in terminology relevant to this study, Merje Kuus refers to Estonia's striving for membership in these international organizations as a "counterweight to the proximity of the Orthodox civilization." As the legal statehood of Estonia was restored and reconfirmed by the international community, the Estonian government officially declared the Estonian Soviet Socialist Republic a product of an illegal occupation and a political entity that was now null and void. Due to that newly declared illegality of that Socialist Republic, those who had come into Estonia during the Soviet period could no longer claim they had done so legally. Reapplication was necessary to obtain legal alien status and language proficiency was required to obtain full, naturalized citizenship. ${ }^{52}$ Though the Western institutions whose approval and admittance Estonia sought stressed integration and fair treatment of minorities, they also subscribed to the Estonian leadership's view of security and stability as the primary objective. In the early period of sovereign territorial re-imagination and taking into account a history laden

\footnotetext{
${ }^{50}$ Laar, "The Restoration of Independence in Estonia," in Estonia: Identity and Independence, 227. Mati Hint is an Estonian linguist and educator who contributed to the independence movement by lobbying for Estonian culture, highlighting the primary importance of writing, publishing, and educating in the native language. One of his most famous contributions on this subject was his speech entitled "The Baltic Way," which he delivered in 1989 at the Baltic Assembly in Tallinn.

${ }^{51}$ Merje Kuus, "European Integration in Identity Narratives in Estonia: A Quest for Security," Journal of Peace Research 39, 1 (2002): 97.

${ }^{52}$ Gregory Feldman, "Culture, State and Security in Europe: The Case of Citizenship and Integration Policy in Estonia," American Ethnologist 32, 4 (2005): 682.
} 
with foreign occupation, Estonian political elites held the country's security concerns on the same level as nation-state building. Thus, Estonia found itself as another member in the ranks of European countries where "civic" and "ethnic" used within "discourses of state, security, nation and culture... are only rhetorical variations on the theme of national boundaries." ${ }^{53}$ Ultimately, the policy indicated a prioritization of stability through security. Managing integration in a favorable way, blueprinting the variety of identities society could contain and the lines along which interaction between residents should occur, was an essential component of realizing that security. ${ }^{54}$

The belief that identity is partially a choice, a component to be cultivated rather than just inherited, permeates the integration debate in Estonia. The chief tool by which the Estonian government did and still believes one can become Estonian is through learning the native tongue. Evaluating the 2007 pan-European Intune project polls of political elites, economic elites, and the general public, Heinrich Best demonstrated that across the board, Estonia has placed heavy emphasis on individuals mastering the national language in order to be considered a member of the nation. Ninety-five percent of those polled within the general population supported this, as did one hundred percent of the economic elites and $98.6 \%$ of the political elites. ${ }^{55}$ In a way, a conversion of sorts is almost expected in tandem with the acceptance and mastery of the language, as if a Russian-speaker will morph into a full-fledged Estonian. Therefore, it is viewed as threatening when Russian-speakers choose not to ingratiate themselves with the Estonian state through language acquisition, interpreting those who are unable to learn or resistant to the state language as an active choice of Russia over Estonia. For example, Tartu University's Market Research Team in its 1997 report claimed that the failure of non-Estonians living in Estonia to consider Russia's actions as threatening in instances when Estonians do leads to the conclusion "that residing in Estonia, non-Estonians accept and consider normal Russia's potential

\footnotetext{
${ }^{53}$ Ibid, 678. Additional support for this claim can be found in: Merje Kuus, "European Integration in Identity Narratives in Estonia: A Quest for Security," Journal of Peace Research 39, 1 (2002): 95.

${ }^{54}$ David D. Laitin, Identity in Formation: The Russian-Speaking Populations in the Near Abroad, (Ithaca: Cornell University Press, 1998), 13.

${ }^{55}$ Heinrich Best, "History Matters: Dimensions and Determinants of National Identities among European Populations and Elites," Europe-Asia Studies 61, 6 (2009): 926.
} 
malevolent actions against Estonia." integration within Estonia show clearly that elements of cultural difference also become security concerns and are debated with a heavier tone than one would expect.

\subsection{The Orthodox Church in Estonia}

The Estonian government's fear of the formation of two nations within a single state drives its integration policy. The development of separate societies is related to issues of identity and the ways in which it is transmitted. Institutions, often supranational in their reach and influence, aid this transference. This uneasiness with duality in Estonia's national integration concerns is mirrored in the conflict surrounding the two Orthodox churches that call Estonia part of their territory. Verdery's abovementioned work illustrates how dead bodies of past religious leaders can cultivate robust patriotism and church-specific pride. These ancient bodies become physical symbols around which followers of their specific Christian denomination or fellow countrymen can unify, historically legitimize themselves, and achieve their aims together. These bodies become tools, imbued with anachronistic preferences and aims. In the case of Estonia, the role of the bodies can be replaced with the church buildings themselves. The Orthodox churches within Estonia function as similar tools for the groups they represent. Though residing in a largely un-churched state, the two churches have had a role in the reawakening of Estonian nationalism or the ways in which links with Russia, its language, and the Russian minority has chafed against Estonian nationalism.

\subsubsection{The Conflict Between the Estonian Apostolic Orthodox Church and Estonian Orthodox Church-Moscow Patriarchate}

Orthodoxy has existed in Estonia for over a thousand years. Though the country is primarily identified as a Lutheran one in terms of religious preference (if one is to classify this extremely secular society by a Christian denomination), Orthodox Christianity has a long history in this northernmost Baltic state. The Estonian Church fell under the

\footnotetext{
${ }^{56}$ Tartu University Market Research Team, 1997: ch. 7, 3 in Kuus, "European Integration in Identity Narratives in Estonia: A Quest for Security," 98.
} 
jurisdiction of Moscow, until it received autonomous status in 1920. Autonomy within the Orthodox Church means that churches are self-governing to an extent; the head of such a church must still be confirmed or appointed by the autocephalous church to which the autonomous church is subordinate. An autocephalous church is one capable of appointing its own head; the Ecumenical Patriarchate in Constantinople or the Moscow Patriarchate in Russia are examples of such churches. ${ }^{57}$ Therefore, this autonomous status granted in 1920 made the Estonian Orthodox Church responsible for its own affairs, but still dependent on the ROC leadership based in Moscow for appointment of its bishops. The increased atheistic propaganda and persecution of believers by the Communist regime in Russia weakened the ROC and its ability to communicate with those churches beyond Soviet borders but still under its authority. In light of this, the Estonian Church appealed to the Ecumenical Patriarch in Constantinople in 1923 for autocephalous status, in order to no longer remain dependent on a church from which it was so disconnected. Instead of autocephaly, Patriarch Meletius granted the Estonian Orthodox Church a tome of autonomy, a church document officially granting and recognizing its autonomous status from the Moscow Patriarchate, which subsequently altered the title (and therefore the responsibilities) of Archbishop of Tallinn to Metropolitan of Tallinn and All Estonia. ${ }^{58}$ Though this act was technically uncanonical in the eyes of the Church, as it requires recognition of release by the former mother church, the circumstances within the Soviet Union and the inability of the ROC to monitor and advise clergy in their territories warranted such changes for the time being. ${ }^{59}$ This change in status and patriarchal jurisdiction became the crux of the conflict in the newly independent Estonian state in the late 1980s and early 1990s.

\footnotetext{
${ }^{57}$ John Meyendorff, The Orthodox Church: Its Past and Its Role in the World Today trans. John Chapin (New York: Pantheon Books, 1968), 143.

${ }^{58}$ Ecumenical Patriarch Meletios, "Tomos of 1923 on the Autonomy of the Apostolic Orthodox Church in Estonia," in L'Eglise Autonome Orthodoxe D'Estonie (Approche historique et nomocanonique), ed. Archim. Grigorios D. Papathomas and R.P. Matthias H. Palli (Athens: Epektasis, 2002), 55-58. The Department for External Church Relations of the Moscow Patriarchate, The Estonian Church: Background Information, accessed September 1, 2014 http://www2.stetson.edu/ psteeves/relnews/estonia2502.html ${ }^{59}$ Archpriest Igor Prekup, "The Ninetieth Anniversary of the Estonian Orthodox Church (Moscow Patriarchate)," Europaica, April 3, 2008, accessed September 1, 2014, http://orthodoxeurope.org/page/14/143.aspx\#3.
} 
However, this new metropolitan status of the Estonian Orthodox Church disappeared in the wake of the Soviet annexation in 1940. At that time, despite what the ROC leadership viewed as a great sin for leaving its former patriarchate without permission, the Estonian Orthodox Church was reabsorbed into the ROC Moscow Patriarchate, where it remained until the forthcoming schism in 1996. Part of the Estonian Orthodox Church, including Metropolitan Alexander who was acting as the head of the church following the bestowal of the 1923 tome, fled into exile in Stockholm where the Synod of the EAOC remained until the collapse of the Soviet Union. In 1978, the Ecumenical Patriarch Dimitrios proceeded to recognize in a letter to the Scandinavian Metropolitan Paulus that there was no longer a need for the tome given by Patriarch Meletius since the communication between the ROC and the Estonian church had been restored and was being maintained. ${ }^{60}$ The 1923 tome was declared "inoperative" by the Ecumenical Patriarchate, which meant, "that the Tomos could not be enforced within Estonia which at that time comprised part of the Soviet Union; the Tomos, however, was not regarded as being void, invalid or revoked." 61

During communist rule, all churches in Estonia found themselves persecuted and the Orthodox Church could feel the blows most acutely as it still carried the status of the church of the czars and the stigma of being of the old Russia. Here it is important to remember something that often gets forgotten in light of the present-day divide between Orthodox churches in Estonia. All peoples of faith were persecuted during this time, regardless of whether they were native Russian or Estonian-speaking. Those who remained dedicated to their faith as the USSR attempted to build a socialist utopia did so as a form of their own personal resistance. In this way, "Russian Orthodox believers were similar to the Estonian Christians of the same generation." ${ }^{62}$ It is also worth noting that the heads of both the Lutheran and Orthodox churches within Estonia, Archbishop Edgar Hark and

\footnotetext{
${ }^{60}$ Prekup, "The Ninetieth Anniversary of the Estonian Orthodox Church (Moscow Patriarchate)." 61 Ecumenical Patriarch Bartholomew, "Patriarchal and Synoical Act of 1996 Concerning the Reactivation of the Patriarchal and Synodical Tomos of 1923 Regarding the Orthodox Metropolis of Estonia," in L'Eglise Autonome Orthodoxe D'Estonie (Approche historique et nomocanonique), ed. Archim. Grigorios D. Papathomas and R.P. Matthias H. Palli (Athens: Epektasis, 2002), 68.

${ }^{62}$ Irina Paert, Memory of socialism and the Russian Orthodox believers in Estonia, 11.
} 
Metropolitan Alexy, were both recruited during their careers by the KGB and have files indicating their cooperation. ${ }^{63}$

Following Estonian independence, the internal Orthodox conflict came to fruition once more, quickly making past confusion over territorial and patriarchal affiliations appear simple in comparison. Metropolitan Alexy was elected Patriarch, leaving his former position in Tallinn to Kornilii. From Moscow in 1993, Alexy restored the autonomy of the Estonian Orthodox Church that had been first granted in 1920. Following this act, the Estonian Ministry of Internal Affairs requested that all religious associations register with the state. A small group of priests and parishes had been rallying around the idea of continuing in the footsteps of the Stockholm Synod in exile by continuing to view themselves as separate from the ROC, motivated by their belief that the ROC was an oppressive and collusive partner to the former Soviet state and its Russian heir. This small contingent registered as the Estonian Apostolic Orthodox Church, the name with which the newly autonomous Orthodox Church identified and hoped to claim. With this name now taken, the larger contingent of the Orthodox Church in Estonia was left to register under the name of the Estonian Orthodox Church-Moscow Patriarchate (EOC-MP), a nod to both its autonomous status and mother church in Russia. ${ }^{64}$ Failure to acquire the historic name of the Orthodox church in Estonia lost for the EOC-MP any entitlement to the restitution of property that would be forthcoming to the church bearing that name, as it was the name of the sole Orthodox Church in Estonia before the Soviet occupation, now deemed illegal. The value of the churches, buildings and territory that the EAOC received through this restitution act amounted to approximately 400 million Euros and made the EOC-MP parishes using those buildings liable to eviction by their new, lawful owners. ${ }^{65}$

From this point forward, tensions ran high between the two Orthodox churches. Contestation and conflict between the EOC-MP and EAOC regarding property and

\footnotetext{
${ }^{63}$ Priit Rohtmets and Ringo Ringvee, "Religious Revival and the Political Activity of Religious Communities in Estonia During the Process of Liberation and the Collapse of the Soviet Union 1985-1991," Religion, State and Society 41, 4 (2013): 357.

${ }^{64}$ This name was not officially registered until 2002, once the Ecumenical Patriarchate had already absorbed the EAOC into their territory and the EOC-MP had spent years fighting over this name with the Estonian government and over issues of canonical law with the Ecumenical Patriarchate and the Orthodox community at large.

${ }^{65}$ Richters, The Post-Soviet Russian Orthodox Church: Politics, Culture and Greater Russia, 78.
} 
canonical territory flared. Indeed, the Orthodox Church is divided into many territories, and though they often correspond with national, ethnic, or linguistic boundaries, they are not supposed to be national in design, as each canonical territory should pursue brotherly relations with the neighboring leaders, parishes, and dioceses as participants in the same unifying faith. ${ }^{66}$ In 1996, the Ecumenical Patriarch Bartholomew issued a synodical act, reactivating the tome of 1923, thus absorbing the EAOC into his territory. This act was done so due to the profession of continued validity of the tome despite its temporary suspension in 1978. This marked the official "return to the fatherland" of "the exiled Autonomous Estonian Apostolic Orthodox Church."67 The presence of now two autonomous churches, falling under the heads of two different patriarchates, cast Estonia's Orthodox communities into questionable areas of canonical law. The existence of territories of two autocephalous churches overlapping within one country was a technical impossibility and ran counter to Orthodox law. ${ }^{68}$ This problem was somewhat resolved with the meetings of members from both sides in Zurich later in that same year of 1996. Here an agreement was made that allowed individual parishes within Estonia to choose which Patriarch they would follow while also attempting to repair the Patriarchates relationships with each other. ${ }^{69}$ Certain stipulations formulated at this meeting never came to fruition, such as to the agreement to equal status within Estonia, which the EOC-MP interpreted as receiving property from the EAOC that had once been its, thus allowing it to own rather than rent. Richters notes that this agreement, as well as others, made at the Zurich meeting, were more of a testament to good intentions and repairing relationships

\footnotetext{
${ }^{66}$ Meyendorff, The Orthodox Church, 143.

67 Ibid, 68.

68 This impossibility is founded in the "Canons of the Apostles" 12, 14, 15, and 35 which place limitations on the clergy and their ability to serve outside their prescribed ecclesiastical boundaries without permission and approval. This first became necessary with the creation of state-sanctioned dioceses (as opposed to territories dictated by the church alone) at the beginning of the fourth century. To diminish any conflict between the bishops and metropolitans of these smaller territories, the boundaries were strictly observed as limits for leadership and it remains a canonical principle to this day, simplifying to "one city, one bishop, one church." It has been complicated by a number of different Orthodox churches looking to establish leadership in territories where one variety of an Orthodox church already exists. Bishop Hilarion Alfeyev, "One City, One Bishop, One Church-Part I," OrthodoxyToday.org, January 27, 2006, accessed November 28, 2014, http://www.orthodoxytoday.org/articles6/HilarionOneBishop.php.

3. Mendelsohn, "But Enough about Me," 69.

${ }^{69}$ Richters, The Post-Soviet Russian Orthodox Church: Politics, Culture and Greater Russia, 88.
} 
than they were indicators of realistic action. ${ }^{70}$ Such legal issues are resolved by rulings of the Estonian state, rather than by ecumenical councils of Orthodoxy.

Presently, the issue of property remains a sore point of contention. Its continued prominence in dialogue between the churches will be evident further on in this thesis as it found its way into all of the research interviews conducted. This specific conflict has morphed from a legal issue into one with deeper connotations. One priest writes, "we are not fighting for material gain. ... The change of property status, the transfer from being tenants of the church buildings constructed by our ancestors to being property owners is a matter of principle, rather than of material gain." 71 Many within the EOC-MP feel that these conflicts stem from a suspicion of the EOC-MP due to its connection with Russia. However, there is truth on both sides of this argument.

A solution could have been formulated from the beginning of the conflict. Various countries around the world contain Orthodox churches answering to various patriarchs within their borders. However, the ROC views itself as the mother church to Orthodox churches in almost all of the former Soviet republics, a territory which is "religiously defined [as] 'Greater Russia.,"72 This mother church has at the forefront of its international interests the maintenance of its jurisdiction over this region and the continued presence of churches subordinate to its leadership. With the breaking up of the Soviet Union, the ROC did not also want to lose its territory as well and has made this its key focus. The escalated nature of the conflict with the Ecumenical Patriarchate regarding Estonia is an example of this jurisdictional claim. Richters posits that the ROC could have simply termed the Russian Orthodox believers in Estonia as a diaspora, which would then open the door for a conflict-free shared canonical territory between the two patriarchates. ${ }^{73}$ The ROC's failure to do this and instead turn towards defending its territory against encroaching brother churches speaks to the importance that the church leadership in Moscow places on maintaining these historic areas of influence. Rohtmets and Ringvee credit the religious revival that occurred (only to later decline in the years following independence) in Estonia

\footnotetext{
${ }^{70}$ Ibid.

${ }^{71}$ Prekup, "The Ninetieth Anniversary of the Estonian Orthodox Church (Moscow Patriarchate)."

${ }^{72}$ Richters, The Post-Soviet Russian Orthodox Church: Politics, Culture and Greater Russia, 91.

${ }^{73}$ Ibid, 86.
} 
in part to feelings of "national awakening."74 Churches like the Estonian Lutheran Church, historically viewed as the Christian denomination of choice in Estonia, and the newly acknowledged EAOC had overt ties to an Estonian legacy, heritage and culture, in addition to vocally supporting Estonian independence movements. Though the ROC was in favor of the USSR's lessening of restrictions on religious communities, it remained on the fringes of the nationalist movements, fearful of their ability to create new divisions among the peoples of the republics. ${ }^{75}$ In the case of the resulting conflict between the two Orthodox churches in Estonia, such fears were partially justified.

In the early years of Estonia's restored independence, the ROC largely failed to convince Estonians of any real admiration and respect for Estonia beyond its status as a piece of its canonical territory. However, the unavoidable link with Russia thrust an immediate negative stigma on the EOC-MP from the start that it still struggles to combat. Many of the congregations that chose to stay under the leadership of the Moscow Patriarchate did so out of custom and canonical reasoning, rather than out of Russian nationalist vigor. Additionally, the transition of the EOC-MP's legacy from an oppressed fellow faith community to that of an "occupation" church was a harsh turn for the Church's hierarchy and followers to stomach. Many priests and parishioners, including Archbishop Kornilii himself, had been brought before Soviet courts and sent to prisons for the pursuit of their faith. Often, one can hear the EOC-MP referred to as "the martyr church" since it was the church that remained in Estonia during the Soviet times, while the EAOC had gone into exile in Stockholm. ${ }^{76}$ The stripping of this label and its replacement with that of "collaborator" is understandably highly offensive to the EOC-MP. This imposition of an occupation legacy on the EOC-MP has also brought out a more pronounced ethnic dimension to this conflict. Just as both Estonians and ethnic Russians were persecuted by the Soviet authorities, so too do both Orthodox churches contain members of both Estonian and Russian heritage, as well as other Russian-speaking minorities living within Estonia. While most Russian-speakers gravitate towards the EOC-MP and most Orthodox Estonians

\footnotetext{
${ }^{74}$ Rohtmets and Ringvee, "Religious Revival and the Political Activity of Religious Communities in Estonia During the Process of Liberation and the Collapse of the Soviet Union 1985-1991," 383.

${ }_{75}^{7 b i d}$. Richters, The Post-Soviet Russian Orthodox Church: Politics, Culture and Greater Russia, 91.

${ }^{76}$ Prekup, "The Ninetieth Anniversary of the Estonian Orthodox Church (Moscow Patriarchate)."
} 
towards the EAOC, the ethnic divide that has become more pronounced over the years is most detrimental to members of the EOC-MP. Associating with that church has the ability to automatically undermine any chance of distinguishing individual loyalties, background, or national-political feelings. Patriarch Bartholomew's letter to Patriarch Alexy of Moscow in 1996 displayed the prevalence of this snap judgment, asking "how can a Church be called Estonian when it is made up of Russian immigrants?"77

Today, though the conflict between the two churches no longer rages as it did in the first formative years of the new Estonian state, relationships between them remain cold and distant. One interviewee encouraged me to take note of how the Archbishops interacted at formal events, exclaiming, "it is amazing to see how they can enter the room without one single look or glimpse at the other representative,... how they can just avoid each other. Even if you look at the pictures, they don't stand side by side."78 The latest Tegevusaruanne (activity report) from the Estonian Council of Churches gives the numbers of faithful for each respective church, though it should be noted that membership is selfreported. The EAOC has 65 congregations and approximately 28,000 members. The EOCMP has 36 congregations and approximately 170,000 members. ${ }^{79}$ Determining how these churches influence the lives of those members and to what extent the politics at the top of their hierarchies permeate through their congregations will help to separate reality from long-standing grudges at the top.

\subsubsection{The Estonian Council of Churches}

The Estonian Council of Churches ${ }^{80}$ (ECC) was founded in 1989 with the intention of bringing together the leaders of the various Christian churches in Estonia, promoting a culture of increased understanding and brotherhood and pursuing the mission of furthering

\footnotetext{
${ }^{77}$ Ecumenical Patriarch Bartholomew, "Letter of Ecumenical Patriarch Bartholomew to Patriarch Alexy of Moscow Concerning the Orthodox in Estonia," Orthodox Church of Estonia, February 24, 1996, accessed August 31, 2014, http:/www.orthodoxa.org/GB/estonia/documentsEOC/reponseAlexis.htm.

${ }^{78}$ Priit Rohtmets in discussion with the author, June 7, 2014.

${ }^{79}$ Eesti Kirikute Nõukogu. Tegevusaruanne. Tallinn, Estonia: 2013, 7. Upon receiving this source from one of my interviewee's I was told to take the numbers reported with a grain of salt, due to their self-reported nature and the tendency of the Orthodox churches to compete with each other via this avenue.

${ }^{80}$ In Estonian: Eesti Kirikute Nõukogu.
} 
Christian values and growth within the country. While today the ECC has ten member churches, the ROC is generally credited with initiating the birth of this Council. Patriarch Alexy, then Metropolitan of Tallinn and All Estonia, was an instrumental force in bringing about such a union, as the Russian church held more sway with the Communist authorities still in power at the time. According to Kuno Pajula, former Archbishop of the Estonian Evangelical Lutheran Church and one of the initiating founders of the ECC, "a new organization could be established only with the permission of the authorities, and the support of the Russian church made it possible to obtain such permission." ${ }^{\prime 1}$ The initiative for this idea from the head of the ROC is widely recognized by the ECC and church leaders that were present at its creation.

The Council deals with shared concerns and issues with which all members can identify and work towards solving at the center of its objectives. Certain nuances regarding the founding and early years of this organization are worth noting. The charter document of the ECC initially included a phrase that translates to "protecting the rights of the Estonian nation," but this was changed to "protecting the rights of the Estonian people." 82 A precursory meeting to the founding of the ECC spoke to the desire of having a Council that "contributes to mutual understanding between different national groups among the Estonian population" as an aid to mediating social problems in a peaceful way. ${ }^{83}$ Both of these instances demonstrate the desire to concentrate more on the needs and problems of the people living in Estonia, rather than the politics of the nation that were coming to the fore. This proved difficult, however, especially during the first years of the ECC's existence, and particularly in the case of the ROC. Calling for peaceful resolutions between conflicting groups, Metropolitan Alexy encouraged greater education on the topic of "love and brotherhood between the Estonian and Russian nations," particularly stressing his own

\footnotetext{
${ }^{81}$ Kuno Pajula, April 21, 2004. Interview by Eerik Jõks and Tauno Teder, quoted in History of Estonian Ecumenism (Tallinn: Estonian Council of Churches, 2009), 243.

${ }^{82}$ Riho Saard, "Establishment of the Estonian Council of Churches," in History of Estonian Ecumenism, ed. Riho Altnurme and Priit Rohtmets. (Tallinn: Estonian Council of Churches, 2009), 253.

${ }^{83}$ Riho Saard, "Establishment of the Estonian Council of Churches," in History of Estonian Ecumenism, ed. Riho Altnurme and Priit Rohtmets, 241.
} 
Estonian and Russian roots, as the realization of independence appeared on the horizon. ${ }^{84}$ He expressed hope in the Orthodox Church's love of unity to guide the relationships of Christian brethren and laid out criteria through which the churches could work together through an ecumenical council. ${ }^{85}$

The conflict between the EAOC and the EOC-MP, previously detailed, mainly occurred through the avenues of legal disputes over government rulings regarding registration and property. The ECC attempted to preserve the collaborative nature of the organization's original premise. However, once the EAOC submitted an application for admittance into the Council, the ECC had no choice but to enter the fray. The Estonian Ministry of the Interior verified that the EAOC was indeed a registered church with the state government, which condoned its inclusion into the ECC. In addition to clearing the EAOC for membership, the Estonian government pointed out that the Orthodox church cited on the rosters of the ECC was one not registered with the Ministry, and therefore could not be considered as an official church in Estonia. ${ }^{86}$ The ECC opted to temporarily stop funding the EOC-MP during this time of legal dispute between the church and the state, though choosing to keep aside the funds the church would typically receive until the conflict was resolved. At the same time, the new Metropolitan of the EOC-MP, Kornilii, brought his request to the ECC to use the Council as a mediator after encountering a deadlock with the state officials.

The Council initially consented to the Metropolitan's request but soon ruled that it could not settle such a disagreement, which needed to be dealt with by the Orthodox churches themselves. As the conflict continued on for a number of years, the ECC relegated both churches to observer status, rather than full membership. At the declaration of Patriarch Bartholomew's acceptance of the EAOC into his canonical territory, the conflict between the churches peaked and the ECC was moved to make a formal proposal

\footnotetext{
${ }^{84}$ Ibid, 255, Rohtmets and Ringvee "Religious Revival and the Political Activity of Religious Communities in Estonia During the Process of Liberation and the Collapse of the Soviet Union 1985-1991," 371-372.

${ }^{85}$ The four fields being 1) peace and disarmament 2) caring for and defending the environment 3) fight for morals and spirituality 4) fight for and defense of cultural heritage

${ }^{86}$ Priit Rohtmets, "Development of the Membership of the Estonian Council of Churches," in History of Estonian Ecumenism, ed. Riho Altnurme and Priit Rohtmets. (Tallinn: Estonian Council of Churches, 2009), 285 .
} 
to the Estonian government. It advocated an end to the exclusive property rights of the EAOC, to be replaced by a neutral managing party that would then rent out these buildings and land allotments to all Orthodox congregations, regardless of their patriarchate affiliation, for no charge. The ECC nominated itself as this neutral party, but was denied the opportunity to follow through on this plan. Instead, the ECC was deemed by the government to be too closely involved, particularly with the EOC-MP as it was one of the main founding members of the Council. ${ }^{87}$

The ECC followed the debate between the two Orthodox churches closely. It voiced particular praise for the EAOC when it took strides to end the conflict and reestablish positive relationships with the EOC-MP and its Moscow leadership. However, the Estonian state's decision to decline the registration of the EOC-MP refueled the conflict, to the point that once again the ECC voiced its disapproval formally with the state. In the face of public criticism from the Council, the government moved forward with the EOC-MP registration, contingent on the church's rejection of any claim to legal succession between the church in the first independent Estonia and the present one. After fighting for this very claim for a number of years, the EOC-MP gave up the debate and accepted the terms in eager pursuit of the formal state recognition and council membership that it had been denied. ${ }^{88}$ The ECC remains today the main forum through which the two Orthodox churches interact. Though relationships remain generally cold and unfriendly, the ECC provides these churches, as well as all the other Christian churches of Estonia, with a place where they can focus on the goals and hopes for the country that they share in common. The Council is also instrumental in collecting information and creating publications that give up-to-date pictures of the faith topography within Estonia.

\footnotetext{
${ }^{87}$ Ibid, 293-294.

${ }^{88}$ Ibid, 303-305.
} 


\section{Data and Analysis}

The following section will concentrate on the presentation and analysis of the data that forms the core of research for this thesis. This material comes in two main parts: statistical data from various sources and personal interviews with experts. Each of these elements will be supplemented by the theoretical framework introduced earlier on in this thesis, additional secondary texts, and pertinent media excerpts. The key focus will be placed on the three research aims of determining whether religion fosters identity within minority groups in a significant way, whether religious communities linked with minority groups help or hinder their overall integration into society, and ultimately determining whether religion has an important place in the processes of reconciling national and minority identity.

\subsection{An Ethnic or Christian Identity?}

The Estonian Council of Churches has conducted surveys under the name of "Elust, usust ja usuelust" (EUU, which translates to Life, Religion and Religious Life) every five years from 1995 until the present regarding matters of faith and belief among people living in Estonia. ${ }^{89}$ The surveys from the years 1995, 2000, and 2005 were conducted by mail. The results could only be calculated from those surveys, which were mailed back to the ECC. Many of the experts interviewed for this thesis, following the dictates of common sense, noted that the survey results were affected by the willingness of individuals to participate. It can be assumed that those who returned their surveys personally viewed the topics of faith and religion as important ones or simply had distinctive views on the matter that they wished to share. I was fortunate enough to obtain the computational tables of survey data from the Estonian Council of Churches in which the numbers and percentages of responses were recorded and then further broken down into categories such as age, language of survey, believer or non-believer, etc. ${ }^{90}$ These particular surveys not only provide a picture of the Estonian religious landscape, but also allow for a general overview

\footnotetext{
${ }^{89}$ The next survey is forthcoming in 2015 .

${ }^{90}$ Surveys were sent out in two language formats, Estonian or Russian. The number returned in each language is recorded in the tables. There is also a breakdown on the responses from each language category of the surveys for each question.
} 
of the trends in this segment of civil society over a span of ten years. I purposefully exclude the most recent survey from 2010 from this initial part of my discussion because, although it accomplishes these tasks as well, it does so more thoroughly and therefore I will address it separately and in greater detail.

In 1995, approximately 1,500 surveys were returned from which to elucidate results. Of those, 961 were Estonian language surveys and 545 were Russian. While there are Russianspeakers living in Estonia who are not ethnically Russians, perhaps hailing from another former Soviet republic, this distinction between language and ethnicity is not made in any of the four surveys conducted by the ECC. The only differentiation between Estonians or Russians is made through the language category. However, it is more than likely that most of the respondents to the Russian language version of the survey were indeed ethnic Russians since according to the Estonian Ministry of Culture, of the national groups living in Estonia, 69\% are Estonian, 25\% Russian, with only 2\%, 1\%, and $0.8 \%$ of the population are made up by Ukrainians, Belarusians, and Finns, respectively. ${ }^{91}$ Of those who answered the Estonian-language surveys in 1995, only $15 \%$ confidently classified themselves as believers, as opposed to the Russian respondents of whom $37.4 \%$ claimed to be believers. Alternatively, the Estonian-language surveys were completed by more individuals who identified themselves as staunch atheists than those who completed the Russian surveys. ${ }^{92}$

This trend continues throughout the 2000 and 2005 surveys. Almost $62 \%$ of the survey participants in 2000 who identified themselves as believers were those who had filled out the Russian-language survey, as opposed to those who responded to the Estonian version, who composed only $22.4 \%$ of self-professed believers. In $2005,43.6 \%$ of those claiming to be believers had filled out the Estonian surveys, with the other $56.4 \%$ of believers coming from those who had chosen the Russian-language option. These numbers are percentages of those that claimed to be believers, which on its own, is consistently a small group among the overall pool of survey respondents each year. Overall, when not broken down according to language, the number of those that claim themselves as believers consistently remain

\footnotetext{
91 “Cultural Diversity," Republic of Estonia Ministry of Culture, accessed September 7, 2014, http://www.kul.ee/en/activities/cultural-diversity.

92 EUU 1995, Q32
} 
well below $50 \%$ of the population. ${ }^{93}$ However, these percentages have the potential to suggest that believers, though a minority, are becoming a significant one among both Estonian and Russian speakers. An interesting trend has been the increase in the number of those who call themselves believers over this ten-year span. One could postulate that this trend is linked to the nature of the survey: those who view religion as more important will be more enthusiastic about filling out and returning the survey. This seems especially likely when considering the 2010 EUU surveys. Conducted face-to-face rather than through the post, this round of surveys engaged a more diverse sampling of the population, additionally speaking to many people who potentially would not have taken part if a survey had simply shown up in their mailbox. In the 2010 survey, those who identified themselves confidently as believers only composed $12.7 \%$ of the overall survey base. The category with which respondents identified most was "indifferent towards believing," with $33.3 \%$ of total participation. This much smaller percentage than those recorded for previous years leads one to believe that the population sampling method was indeed a factor in the results, rather than a sudden pronounced aversion to religion in the last five years.

What the surveys do show, regardless of their year, is the greater likelihood of minority ethnic groups to identify themselves as believers or in religious terms, when compared with ethnic Estonians. Ringo Ringvee, an advisor in the Department of Religious Affairs at the Ministry of the Interior, notes that typical congregation numbers for Estonians and Russians are fairly close. The Estonian Council of Churches' 2010 EUU survey validates this assumption. The Lutheran Church, cast as the prototypical "Estonian" faith option, and the Orthodox Church, the assumed "Russian" church of choice, boast $44.2 \%$ and $32.4 \%$ of all survey participants respectively, both clearly outranking the other Christian denominations and faiths listed. In the 2011 census the following year, of the quarter of the Estonian population claiming a religious affiliation, sixteen percent identified as Orthodox, as compared to Lutheranism's ten percent. ${ }^{94}$ After indicating the relative closeness in the

\footnotetext{
${ }^{93}$ In $1995,23.1 \%$ of the survey respondents claimed to be believers. In 2000 and 2005, the percentages of the overall were $35.7 \%$ and $42.1 \%$ respectively.

${ }^{94}$ Statistics Estonia, http://www.stat.ee/65352?highlight=orthodox. One interviewee stated that Lutheranism is often reported to be the majority faith in the event that Orthodox church affiliation is divided between EAOC and EOC-MP. In the case of Statistics Estonia census data, this distinction was not made, therefore leading to a Orthodox majority.
} 
numbers of those professing membership in a congregation, Ringvee concludes that the difference between Estonians and minority groups is in the prevalence of actual belief and in the way by which it is incorporated into their identity. ${ }^{95}$ Putting his finger on a subject that is difficult to quantify through census or ECC surveys, Ringvee employed the word "identity" to locate the noticeable difference between claiming a faith community-even if the levels of activity and true Christian belief remain low — and minority status. "Maybe it has something to do with, well let's say, immigrant background...It's part of the identity. ...Basically every ethnic minority here, when they have these kind of strong religious traditions, it's not just religion. It's also part of the ethnic identity." ${ }^{96}$ Despite Estonians' growing reputation for being an incredibly secular, un-churched nation, they have also shown the same tendency to locate their ethnicity in conjunction with a religion, when experiencing minority status. "Even the religiously passive Estonians, when they were exiled, the exile communities of the $50 \mathrm{~s}, 60 \mathrm{~s}, 70 \mathrm{~s}$, and $80 \mathrm{~s}$, then the religion was not just religion. It was also the ethnic part."97

Ringvee's explanation of religion's more prominent role among ethnic Russians was one shared by all of my interviewees. Over the course of a week, I spoke with six experts residing in the cities of Tallinn and Tartu whose connections to my study ranged from the Estonian Council of Churches executive committee, to priests of both Orthodox churches and professors of religion. I went into each interview with a prepared list of general questions, and occasionally some additional ones, oftentimes specific to their role. ${ }^{98}$ Each interviewee received this key question: "Is the Russian Orthodox community centered more on a national/cultural/ethnic identity or on a Christian identity?" This was a key question not only in my study, but also from the perspective of my respondents, many of whom spent an exponentially greater amount of time expressing their opinions on this question compared to others and showing detail in clarifying its nuances. Archpriest Toomas Hirvoja, a native Estonian and priest of the Estonian Orthodox Church-Moscow Patriarchate, commented on the fine line between Orthodox churches and the ethnic link

\footnotetext{
${ }^{95}$ Ringo Ringvee, in interview with author, June 3, 2014.

${ }^{96}$ Ibid.

97 Ibid.

98 This list of questions can be found in the appendices of this thesis.
} 
with which they are often bestowed. He used the term ethno-phyletism, which is the unfortunate situation when a church and nation's boundaries are confused; the church becomes classified by the components of the country in which it resides, identifying strongly with a single race, language, or territory and forgetting its broader Christian mission. ${ }^{99}$ This is un-canonical according to the Orthodox Church, but becomes a complicated issue as most of the various Orthodox churches in Central and Eastern Europe are somehow defined by the country where they are located or the ethnicity that composes its congregation. Some would classify the schism between the two Estonian Orthodox churches as being motivated by ethno-phyletistic sentiments and that the separation between the churches at present has retained ethnicity as its primary line of division. Father Toomas indicated that one does not have to forsake one's ethnicity, language, or nation in order to be a good Orthodox congregant, but instead simply acknowledge the primacy of the Orthodox Church's unity within this hierarchy of personal loyalties. ${ }^{100}$ For comparison, a similar philosophy is evident in the Roman Catholic Church, where the Pope is not looked to as a political leader above one's head of state, but members of the faith are encouraged to vote and live along the lines of Church principles and doctrine within their various communities. In both situations, believers are called to live their cultures, but not at the expense of or contrary to their overall faith.

This is easier said than done and the perceptions of where each marker-Christian or ethnic - falls along the chain of importance was what I hoped to gain from my interview subjects. The majority of my interviewees acknowledged that the EOC-MP evoked more of an ethnic and nationally-based identity than one purely grounded in a shared faith. Some hesitated to give a decisive answer, diplomatically qualifying their statements by saying that the trend of aligning closer with ethnicity than with faith was a visible phenomenon, but not necessarily one indicative of the entire EOC-MP minority population. ${ }^{101}$ Others unequivocally declared that "definitely" the national and cultural elements took

\footnotetext{
${ }^{99}$ Father Theodore Paraskevopoulos. "Ethnophyletism." Sermon, Ancient Faith Radio, December 13, 2010, http://www.ancientfaith.com/podcasts/isermon/ethnophyletism.

${ }^{100}$ Archpriest Toomas Hirvoja, in interview with author, June 6, 2014.

${ }^{101}$ Interviews June 2, 2014, June 3, 2014.
} 
precedence. ${ }^{102}$ Two priests from the EOC-MP provided remarkably similar responses to this question, illustrating in their answers the blurred lines between ethno-phyletism, religion, identity, heritage, and external homelands.

When asked the aforementioned key question, Father Toomas felt that particularly in the religious community he shepherds, an Orthodox church in Nõmme, faith is at the forefront. Particularly as an Estonian in what many people see as a distinctly Russian church, he professed that he does not feel that he ministers in a church that is not his own. After all, its title is the Estonian Orthodox Church-Moscow Patriarchate, not the Russian Orthodox Church. He serves a local church, a local people and thus feels that the primary connection is formed through this faith community rather than through a shared ethnicity. Both Father Toomas and a fellow EOC-MP priest, Father Igor, drew attention to the vast number of Russians or Russian-speakers who claim Orthodoxy as their religion, yet the small numbers who actually attend services and actively participate in the church, as if to show that being Russian does not make that person a practicing member of the Orthodox Church. The EOC-MP churches face the same quandary as their brother churches in Russia; many Russians claim to be Orthodox, but each Sunday the services are poorly attended. "Where are those people?" Father Toomas asked laughing, before labeling these already professedly Orthodox a primary — and paradoxical — field for missionary work. ${ }^{103}$ The 2010 EUU survey also testifies to this paradox. Equipped with questions that probed deeper for moral judgments, the results showed that Christian principles were not claimed by as many as those who claimed to be believers or even members of the congregation. While some questions resulted in a majority of participants being morally and socially opposed to homosexuality, human cloning, infidelity, and other behaviors that the church typically does not condone, other issues such as euthanasia, premarital sex and cohabitation

\footnotetext{
${ }^{102}$ Interview June 7, 2014.

${ }^{103}$ Archpriest Toomas Hirvoja, in interview with author, June 6, 2014. In another interview with Dr. Priit Rohtmets, a professor of religion at the University of Tartu, he too referred to the Russian minority as a potential mission field for the church. However, he expressed his disappointment in the EOC-MP for only focusing on that specific minority group, whether as members or winning them over as members, rather than concentrating on all minority and majority groups within Estonian society as an equally desirable population for their church.
} 
enjoyed the support of the majority of those polled. ${ }^{104}$ Through these surveys, a slightly more traditionally conservative picture is painted of Estonia, but they also indicate that religion is potentially not the main motivator for these attitudes, as respondents appear to pick and choose rather than follow an unwavering line. In fact, this inconsistency of adherence to church beliefs speaks directly to the strong cultural basis of the church, rather than one of faith.

Despite the diversity of attitudes and creeping secularism each of these priests spoke of, later on in their interviews, unsolicited comments were made that indicated a clear connection between Russian ethnicity and the church. Father Toomas, an Estonian by birth, was initially baptized in the Lutheran church but sought deeper spiritual communion that he did not feel this church could provide. This search led him to the Orthodox Church, what is now the EOC-MP, for at the time of his conversion the schism had not yet occurred. When addressing the question as to why Orthodoxy appears to be growing in popularity in Estonia in recent years, he supposed that his own experience might mirror those of other Estonians who are looking for something more mystical, something that better satisfies their spiritual needs. ${ }^{105}$ For Russians though, "they are discovering their roots; this is quite natural for them to find Orthodoxy if they are looking for their roots."106 Here he links Orthodoxy and Russianness quite closely, saying that Orthodoxy is inevitably found in traditional Russian culture. Father Igor Prekup speaks similarly. When asked if Orthodoxy is tied to an ethnic, national culture, he too first reminded me that not all Orthodox are Russian. Instead of following this statement with the expected "nor are all Russians Orthodox," he chose to speak about the way in which the Russian nation had been distinctively shaped by Orthodoxy. Prior to Christianity (in this case, the chosen form was Orthodoxy), Russia was merely a territory inhabited by Slavic tribes. Orthodoxy unified them around a central Orthodox political figure.

\footnotetext{
${ }^{104}$ EUU 2010, K3.

${ }^{105}$ Ringo Ringvee posed something similar. There has been no research into why the numbers of Estonians joining the Orthodox Church went up between the 2000 and 2011 censuses. It's a matter of religious and personal preference, but Ringvee used similar phraseology as Hirvoja, supposing that the mysticism inherent in Orthodoxy and quite different from Protestantism was drawing new believers to it.

${ }^{106}$ Archpriest Toomas Hirvoja, in interview with author, June 6, 2014.
} 
This belief in Orthodoxy as the central factor that had not only created a "national religion [but] also helped the formation of the state" echoes the symphonia theory that Zoe Knox puts forth. ${ }^{107}$ Just as a symphonic structure removes any separation between ruler and church, Prekup sees the two - the Russian nation and the Orthodox Church - as historically indivisible to this day. Historically, I would agree that the Orthodox Church must be acknowledged as a central institution in Russia's pre-Soviet history. It was the priest's following comments on modern Russians and Russian-speakers link to that history that clarified what he saw as an indivisible bond between Orthodoxy and ethnicity. "If a Russian person, a Russian-speaking person is not Orthodox, he doesn't find, doesn't have this association with his national roots. He doesn't connect with these national roots." The priests claim that their faith community is Orthodox first and Russian and/or Russianspeaking second. Certainly, this is plausible for many of their parishioners. However, their stress on Orthodoxy as a central component to the Russian ethnic heritage continues to enter into their narratives. Combined with the number of those who claim Orthodoxy as their religious denomination opposed to those who actually express belief in its teachings, one can conclude that the Church offers a greater ethnic resonance than faith-based significance. To invert Grace Davie's original phrase, Russians belong to the Orthodox church without believing and, in doing so, they allowing themselves to be vicariously Orthodox but wholly culturally Russian.

This Church's cultural significance is not only witnessed in the EOC-MP. An EAOC priest, Father Aivar Sarapik, chose to highlight the sameness of Orthodox tradition across the board - the liturgy, the theology, the dogma. Conflict springs from the culture and it is the culture attached to each church (the EAOC and the EOC-MP) that separates them rather than joining them together. "We don't need the Moscow or whatever it is, in group dynamics," he said, meaning the different brands of Orthodoxy. "What we need is the Church and that's what counts." 109 The information gleaned from these interviews and surveys complements the findings of scholarly literature. Jaanus Plaat conducted a study where he compared and cross-examined a wide-array of religious survey data taken among

\footnotetext{
${ }^{107}$ Father Igor Prekup, in interview with author, June 4, 2014.

${ }^{108}$ Ibid.

${ }^{109}$ Father Aivar Sarapik, in interview with author, June 3, 2014.
} 
Estonians and Russians in Estonia, incorporating some of the surveys that this thesis has also employed, to construct a better picture of Estonians' religiosity, as well as that of the country's minorities. He too concluded that Orthodoxy contributed to the construction of identity for the Russian minority, in a strong ethnic sense rather than a deeply religious one, though its members were openly more religious than their Estonian counterparts. Just as joining the Lutheran church became a way in which Estonians expressed their discontent, rebellion, and ethnic solidarity during Soviet times, Plaat claims that so too do the Russians in Estonia claim Orthodoxy as an assertion of their Russianness within Estonia. 110 "Where ethnicity and religion are correlated in a population that lives in the sphere of dominance of a multinational state..., religion is likely to become a core element of national identity formation and a rallying point." 111 Though Estonia's population is small, the prominence of the ethnic and cultural connection between Russia, the Orthodox Church and the Russian minority still appear strong and central to those who professed Orthodox membership.

Religion comes equipped with a cultural collective memory, a memory that is constantly morphing, deciding what is important to remember and record, and what is superfluous and can be forgotten. This memory is "mobilized" in the words of HervieuLegér through religion, expressed in its ability to bring significant history to the forefront and enliven it by practices such as the liturgy and other religious traditions. ${ }^{112}$ Belonging to this "lineage of belief" is the foundation of religious self-definition, placing its strength in long-standing tradition and group existence, legitimized by its longevity. This is clear in Prekup's comments on the history of the Russian state and the dependence of its formation on the Russian Orthodox Church. This impressive claim elicits pride in one's Russian and Orthodox roots and taps into a cultural continuity that transcends time. Once again, Father Toomas provides an excellent example from his own life of the value that the church under the Moscow Patriarchate places on continuity and loyalty. At the time of the schism, his spiritual father gave him the freedom to choose to break with the church and follow his

\footnotetext{
${ }^{110}$ Jaanus Plaat, "Christian and Non-Christian Religiosity in Estonia in the 1990s: Comparison of Estonians and Other Ethnic Groups,” Pro Ethnologia 14 (2002): 128.

${ }^{111}$ Best, "History Matters: Dimensions and Determinants of National Identities among European Populartions and Elites," 937.

${ }^{112}$ Hervieu-Leger, Religion as a Chain of Memory, trans. Simon Lee, 124.
} 
fellow Estonian clerics or to stay in the church that had baptized him, confirmed him, and ordained him as a priest. He did not believe in breaking with the church for national or ethnic reasons, nor did he desire to sever himself from the "lineage of belief" that the church under the Moscow Patriarchate in Estonia contained. Often, he calls the ROC the "mother church" to the EOC-MP, indicating a canonical loyalty as well as a reminder of the kinship-like ties between the Moscow see and its autonomous Estonian arm.

Hirvoja's parish exemplifies the way in which the EOC-MP ethnically and culturally connects with and furthers the Russian identity within Estonia. His church has helped to start an Orthodox private school in Tallinn that operates with some state funding in addition to students' tuition fees. Still in its early years of existence and with plans to grow each year, the school was created as an Estonian school option that would still preserve Russian culture, primarily through continued language instruction. From the start, the school has had instruction in Estonian and Russian, though Russian speakers receive more of their classes in Russian. This decision was made in an effort to keep Russian youth progressing in their writing skills, as many of them in Estonian schools would lose a significant portion of their Russian writing proficiency, simply from lack of practice. The school ultimately furnishes a trilingual education, teaching students in Estonian, English, and Russian. In addition to classes, the students attend liturgical services at Father Toomas' church of St. John the Baptist once a month. This Orthodox primary school does further the elements of the Russian culture and ethnicity, primarily through language, but it is a good example of the way in which the line can be effectively straddled; though it still maintains distinctly Russian elements, it acknowledges and participates in Estonian society. The school is but one example of the way in which the church draws its strength from a cultural base. Rohtmets also mentioned the way in which the EOC-MP works through Russian cultural organizations, such as veterans groups or well-attended public celebrations, to recruit more parishioners. The shared Russianness forms the initial base, the impetus for introduction and then inclusion, showing once again that the national-cultural motivations are quite strong and, in line with findings drawn from the surveys, remain the strongest point of connection with the church, over the Christian faith. 


\subsection{A Detrimental Relationship?}

The role of the EOC-MP among the Russian minority is difficult to deduce primarily because maintaining a cultural connection with one's roots is not necessarily inimical. The Constitution of the Republic of Estonia reserves as a fundamental right of all people living in Estonia "the right to preserve his or her national identity." 113 Therefore, regardless of whether faith or ethnicity takes precedence, the Church's fostering of a Russian national identity is technically not prohibited. Yet, Russia's Concept of Foreign Policy claims the right to defend the national identity of Russians dwelling beyond its borders, harkening back to Brubaker's prediction about the perspective of external homelands towards their ethnic brothers living beyond their borders. The Russian Federation's concern for Russian nationals abroad does not stop at monitoring their rights, but extends to "preserving the cultural and ethnic identity of the Russian diaspora and its ties with the historical homeland."114 The EOC-MP's role as a cultural institution in Estonia makes it a clear possible choice for extending the influence of the Russian state to the ethnic Russian population. This connection is generally viewed with uneasiness and suspicion by ethnic Estonians.

In the same Concept of Foreign Policy, the Russian government also articulates an interesting definition of "soft power." In the eyes of the Estonia's larger next-door neighbor, this term originally coined by Joseph Nye, is seen as a "comprehensive toolkit

for achieving foreign policy objectives" through means other than traditional diplomacy. ${ }^{115}$ The document then proceeds to note how soft power has been used unfairly or unlawfully by other nations to undermine the stability of states and intervene in their internal affairs. This brief point in the overview of Russia's approach to foreign policy within the modern world and the Russian political leadership's interpretation of the term "soft power" thus

\footnotetext{
${ }^{113}$ Republic of Estonia Constitution, chpt II, sec. 49.

${ }^{114}$ Ministry of Foreign Affairs of the Russian Federation, Concept of Foreign Policy, February 12, 2014, chpt III, sec. 39, e.

${ }^{115}$ Ministry of Foreign Affairs of the Russian Federation, Concept of Foreign Policy, February 12, 2014, chpt II, sec. 20.
} 
sheds light on the distrust of Estonians toward the EOC-MP's actions within their borders when linked with Moscow through the patriarchate.

In believing that soft power is a tool that can be actively utilized, the Russian government attests to actively looking for inroads into societies outside its borders. However, soft power, conceptually, is not a tool to be wielded like a screwdriver or wrench. The toolkit that the Concept mentions aligns metaphorically more with coercion and military strength, rather than the persuasion and attraction of culture, values, and foreign policy that are inherent in the soft power approach. Russia's overt behavior often contradicts the subtle nature of soft power, the art of getting "other countries to want what it wants." Nonetheless, Russia still has the potential to procure the desired soft power results by marketing a culture and then garnering support and loyalty for the ideology that comes with it. ${ }^{116}$ According to Nye, "co-optive power-getting others to want what you want — and soft power resources — cultural attraction, ideology, and international institutions - are not new." 117 Prior to the new Russia, the Soviet Union was well-practiced in performing this kind of persuasion through its myths, personality cults, and overarching communist ideology.

An institution such as a church provides a ready-made historical and cultural connection for the exertion of soft power. It can supply fertile ground in which to plant "preferences or define [the] interests [of others] in ways consistent with its own."118 This in turn opens the door for a minority group to mirror the feelings of co-nationals constituting a majority in an external nation-state along negative lines; "Russian homeland nationalism, moreover, may encourage Russian minorities to adopt more intransigent stances than they would have been inclined to do without support from Russia." ${ }^{119}$ As Russia professes an increasingly active approach in the realm of compatriot policy and soft power influence, and as the ROC comes under increasing scrutiny for tightening bonds with the Kremlin leadership, asking whether the EOC-MP's presence and relationship to a foreign hierarchy is detrimental to Estonian society is a legitimate question. In answer to this question, the

\footnotetext{
${ }^{116}$ Joseph S. Nye Jr., “Soft Power,” Foreign Policy 80 (1990): 166.

${ }^{117}$ Ibid, 167.

${ }^{118}$ Ibid, 168.

${ }^{119}$ Brubaker, Nationalism Reframed, 53.
} 
Estonians I interviewed were characteristically dubious of the Church's subordination to Moscow, with some even doubtful as to whether the EOC-MP would be aware of being taken advantage of.

The Russian minority within Estonia and Russia's clear compatriot policy gives Russia a foothold in the small Baltic nation. It is in Russia's best interest to maintain and even expand this population and continue to influence it. Mr. Eerik Jõks, Executive Secretary of the Estonian Council of Churches from 1994 to 2006 and Chairman of the ECC Theological Commission from 2011 to 2013, still strives to improve dialogue and coordinated growth among the Christian denominations within Estonia. He enjoys positive personal relationships with the clergy of multiple churches, working with them regularly. Yet, even he feels that the EOC-MP is one of the avenues along which Russia could potentially encroach on Estonia, pushing beyond simply defending the rights of ethnic Russians. He cited the then-recent annexation of Crimea as an example of why it "is always good to have a base" of Russian sympathizers, supporters, or nationalists. "I feel that the Russian Orthodox Church is playing a role in this," meaning the continued existence of this base. "I don't say that they get directions from the government, rather that they are used not to integrate... because when you integrate you cease to be an integral community with clear ethnic characteristics." 120 The insular environment of the EOC-MP is conducive to the exclusively Russian base that the Russian Federation hopes to maintain through cultural ties. However, the percentages among non-Estonian ethnic groups that responded to the EUU 2010 question in which they were asked to rank the importance of various things, one being "Estonia, present and future," were remarkably similar to the percentage among Estonian respondents. The highest number of responses for all groups fell under the "Very important" and "Important" labels, numerically vouching for a vested interest among the entire population for the country they call home, regardless of ethnicity. ${ }^{121}$

Additionally, Jõks classified Orthodoxy as a church more concentrated on its established community, rather than one focused on mission and active evangelization. I found support for this viewpoint in my other interviews. When asked about the activities of

\footnotetext{
${ }^{120}$ Eerik Jõks, in interview with the author, June 2, 2014.

${ }^{121}$ EUU 2010, K1.
} 
the Orthodox church and its programs, I was often met with little idea of what the Orthodox church did outside of celebrate the liturgy. As Father Toomas said, the liturgy is the Church's best tool for evangelizing, which is understandable considering the compellingly beautiful, full sensory experience that is an Orthodox mass. Yet, you must first enter the church in order to be evangelized in that case. Even from Orthodox priests, I received answers focused on their pastoral duties rather than actions taken by the congregation that outwardly expressed or served others through their faith. To doubt the existence of good deeds, service, and involvement of individual parishioners in social work would be foolish, but the culture of the Orthodox Church appears simply more inwardly focused on the church's already existing community itself. This quality, coupled with Russia's stated desire to make political and patriotic inroads via cultural avenues, makes the Orthodox Church a prime community through which to further foster an insular Russian minority community.

\subsection{Religion as a Tool of Political Mobilization}

The question of whether this relationship between church and culture, as well as culture and external homelands, leads naturally into a question of the political aspect of the Orthodox church's role and the way it shapes minority conceptions of identity and community. In April and May of 2007, some of the most prominent Russian-Estonian clashes since the fall of the USSR occurred in Tallinn. They revolved around the removal of the Bronze Soldier statue from the center of Tallinn and its relocation to a military cemetery. The statue commemorated the "liberation" of Estonia from German Nazi occupation by Soviet forces, and over time, had become a symbol for honoring the memory of the Soviet soldiers who had died in the Second World War. Its removal begot massive riots, looting, arrests, and one fatality within the city as well as harsh criticism from the Kremlin and the ROC outside Estonia's borders. The Bronze Soldier incident served as Estonia's premier ethnic conflict, still referenced today and still charged with emotion, interest, and debate.

The Orthodox Church in Estonia and abroad in Russia did not stay silent during this conflict. Patriarch Alexy of Moscow condemned the relocation of the statue, as well as the 
bodies of the two unknown Russian soldiers who were buried by it, accusing the Estonian government which had commissioned the action of being irreverent to not only those who had given their lives in the war, but all Russians in general. ${ }^{122}$ Such sentiments echoed those of President Vladimir Putin and his successor, Dmitri Medvedev. The EOC-MP, following the path already established by its mother church in Russia, expressed its disappointment in the decision to relocate the statue. In a statement issued by Metropolitan Kornilii, a call for respect for the Soviet legacy rather than retaliation against was expressed, while no words were given to quell the riots or reprimand violent responses to this change. ${ }^{123}$ Additionally, an emphasis was placed on the frivolity of turning an ethnically neutral statue (a point attributed to the Soviet Union's multiethnic composition) into one charged with present-day disputes. The blame fell mostly on the Estonian state for altering the prism through which it was seen. ${ }^{124}$ The appearance of deference to its Moscow mother church was strong within the EOC-MP hierarchy's response and spoke to the church's tendency to support the Russian see. Additionally, the EOC-MP's response appeared more hostile to the Estonian state than to those who had broken the law, by charging the state with the initial act of provocation.

The case of the Bronze Solider provides a remarkably fitting connection with the work of Katherine Verdery's Political Lives of Dead Bodies. Though not an actual dead body, the Bronze Soldier represented and laid claim to many of the same sentiments as those provoked by the corpses Verdery discusses. The movement, veneration, and celebration of bodies allows the affected populace, as well as outside observers, to track an evolving political process through visible physical change. Though the remains of two unnamed Soviet soldiers rested with the Bronze Soldier statue, it was odd that their relocation garnered fewer uproar or cries of injustice. Rather, it was the most visible element, central to the display, which caused the greatest protest. In her book, Verdery devotes her introductory chapter in part to the subject of statues. She claims that statues, especially those sculpted to depict famous leading figures, bestow those individuals with timelessness,

\footnotetext{
${ }^{122}$ Richters, The Post-Soviet Russian Orthodox Church: Politics, Culture and Greater Russia, 90.

123 Ibid.

${ }^{124}$ Metropolitan Kornilii of Tallinn and All Estonia , Statement to the Media About the Events of April 26-29 2007, May 4, 2007, accessed September 4, 2014. http:/www.pravmir.com/article_218.html.
} 
memorializing them like an icon. ${ }^{125}$ They neither decay nor vanish into obscurity. Yet, when toppled or removed, their humanity and mortality is once again restored, and the lofty ideals or victorious history that they once stood for is altered along with their presence. Verdery uses a startling and aptly religious wording to describe the repercussions of such phenomenon. "Tearing it down not only removes that specific body from the landscape, as if to excise it from history, but also proves that because it can be torn down, no god protects it. ${ }^{, 126}$ I believe this fear of mortality can be particularly motivating in the case of an ethnic minority.

Therefore, following the line of Verdery's reasoning, the church intersects meaningfully with the political in this instance. The church facilitates the lobbying for continued ethnic and cultural respect and unity. One of my interviewees indicated that the membership numbers of the EOC-MP increased following the Bronze Soldier debacle. ${ }^{127}$ Estonia's population censuses indicate the potential truth in this statement. Estonia's two most recent censuses were conducted in 2000 and 2011. In that span of eleven years between the two censuses, the population of the Republic of Estonia has declined by approximately 62,000. In the recording and classification of ethno-cultural characteristics, religious affiliation was also documented. In 2000, seven years prior to the Bronze Soldier conflict, Estonians who declared themselves Orthodox numbered 18,577 while Russians were predictably higher with 104,698. In 2011, though the overall population had declined, both Estonian and Russian respondents indicating an affiliation with Orthodoxy had increased. Approximately 20,500 Estonians and 134, 270 Russians claimed Orthodox as their chosen faith. ${ }^{128}$ These numbers show that despite an overall trend of decline in the population of Estonia, Orthodoxy is still winning over new members. As the trend indicates growing claims to the title, rather than active membership in a faith and, as my interviews indicated, neither Orthodox church is enthusiastically evangelizing within the community, one can postulate that this increase has not necessarily been brought on by the externallyfocused ministry of the churches, but rather a increasing need or desire to identify oneself

\footnotetext{
${ }^{125}$ Verdery, The Political Lives of Dead Bodies, 5.

${ }^{126}$ Ibid.

${ }^{127}$ Dr. Priit Rohtmets, in interview with author, June 7, 2014.

${ }^{128}$ Statistics Estonia, 2000 and 2011 censuses, www.stat.ee.
} 
along this cultural vein. These censuses did not differentiate between the two different Orthodox Churches, which would indeed provide an interesting comparison were that information available, but they do show an increased number of Orthodox in 2011, four years following the Bronze Soldier clash.

Taking into account Verdery's work on the potential of the inanimate to mirror the animate's place in society, it makes sense that the Orthodox Church would grow in its importance as a hub of Russian identity within Estonia. As one icon (the Bronze Soldier) is diminished, the other (the Orthodox Church) grows with the new onus of cultural preservation and advocacy transferred to it. The EOC-MP, more so than the EAOC, grows as other elements of Russian culture in Estonia appear increasingly threatened. Verdery quotes Gillian Feeley-Harnik’s writing, “Ancestors are made from remembering them. Remembering creates a difference between the deadliness of corpses and the fruitfulness of ancestors." ${ }^{29}$ The EOC-MP enables this fruitful remembrance, as evidenced from its plea to remember the greatness of those who fought against the Nazis regardless of their native language or ethnic affiliation. As Estonia grapples with how to process and compartmentalize Soviet and post-Soviet identities and memories, the Bronze Solider being but one example, the EOC-MP can provide a legitimate institution through which ethnic Russians can band together and act politically. This draw to Orthodoxy over a period of years in which Russians and Estonians particularly clashed shows once again that the church's membership is not solely dictated by belief alone and that the label of Orthodoxy does not just denote a faith identity, but one's loyalties and ethnicity as well.

Following the Bronze Soldier incident, Estonia's Centre Party (Keskerakond) began to emerge as an increasingly Russian-friendly political party and it too began to overlap with the Orthodox Church due to this outlook. The number of its supporters dipped during and immediately following the protests and riots, mostly due to the party's support for Russian opinions in this conflict and the resulting departure of former supporters who were of Estonian ancestry. However, numbers rebounded for the party as it became closely linked with fighting for fairness and rights for all groups, though the Russian minority is typically

\footnotetext{
${ }^{129}$ Verdery, The Political Lives of Dead Bodies, 42.
} 
the group on whose behalf they advocate. ${ }^{130}$ Following the Bronze Soldier events, the Centre Party's reputation as the "Russian-sympathetic" or "Russian-supported" political party has grown. Estonia allows even non-citizens to vote in local elections, allowing the Russian population to indeed express its support for what has become labeled as "their" party. The integration survey analysis from 2011 found that while ethnic Estonian voting is spread among all parties, Russian votes tend to either go to the Centre Party or do not get cast at all. ${ }^{131}$ Due in part to the large ethnic Russian population in the capital city of Tallinn, the mayor of Tallinn, who was most recently reconfirmed in his position in November of 2013, Edgar Savisaar, is a member of the Centre Party. In recent years, the party has furthered its negative reputation among Estonians for serving Russian interests by taking funding from Russian companies and cooperating with United Russia, Putin's own political party. ${ }^{132}$ These links with Russian-centered causes, conflicts and groups over the years have cemented its controversial image as the Russian choice in Estonia, drawing consistent Russian support whether or not the issues it addresses impact that sector of the population.

The intersection of the political and the religious is evident in Patriarch Kirill's most recent visit to Estonia in June of 2013. Upon arriving, his first stops were to visit some of the most politically significant sites in Tallinn before meeting with mayor and Centre Party politician, Savisaar. The Alexander Nevsky cathedral, an architecturally traditional Russian Orthodox structure that belongs not to the EOC-MP, but the ROC, was the first destination, followed by the Bronze Soldier in its new location within the military cemetery. The impetus for the visit was a commemoration of the reinstatement of the tome, given by Patriarch Alexy, to the EOC-MP prior to the schism, through which its autonomy was

\footnotetext{
${ }^{130}$ Marge Tubalkain-Trell, "Populists coming back," The Baltic Times, April 9, 2008, accessed September 10, 2014, http://www.baltictimes.com/news/articles/20186/\#.VBcXeEum1ME. Karin Kangro and Helen Mihelson, "Centre Party popularity towering in Tallinn," Postimees in English, August 8, 2013, accessed September 10, 2014, http://news.postimees.ee/1318780/centre-party-popularity-towering-in-tallinn.

${ }_{131}^{131}$ Estonian Integration Monitoring Summary 2011, 16.

${ }^{132}$ Chris Terry, "Estonian Centre Party (KESK)," Demsoc Europe, February 27, 2014, accessed September 10, 2014, http://europe.demsoc.org/2014/02/27/estonian-centre-party-kesk/
} 
restored. ${ }^{133}$ Later on in his two-day visit, Patriarch Kirill went to the Lasnamäe district of Tallinn, the most populated Russian district of the capital, to bless the newly-constructed Orthodox church there. Earlier in 2012, this same church had unveiled a bust of the late Patriarch Alexy in the surrounding courtyard of the church. Verdery's argument can also be applied here. With the memorializing of this figure, Alexy is enlivened once more within the community, the connection between Tallinn and Moscow strengthened, standing as a daily reminder of the shared Estonian and Russian identity that one could potentially foster through the EOC-MP. Its dedication was attended by Savisaar who spoke of Alexy as "our outstanding fellow-countryman," a verbal recognition of Alexy's years spent living and serving in Estonia. ${ }^{134}$ Patriarch Alexy undoubtedly did much for Orthodoxy in Soviet-era Estonia and post-communist Russia, saving church buildings, defending the faith, and helping to create a new civil society in which religion was accepted after the fall of communism. ${ }^{135}$ However, these examples all show the close link to Russia, not just through the shared Orthodox faith but the strong political and cultural connections as well. It is the consistent reminder of these bonds through visits and memorials that many Estonians view as threatening, as something more present and potent than just a shared history.

The aforementioned church in Lasnamäe has proved to be a site that has stirred up strong sentiments of identity among Russians in Estonia, though in a less explosive manner than the Bronze Soldier monument. The district itself is known for its sizeable Russian population and typically forms a reliable foundation of support for Savisaar and his Centre Party. During Estonia’s famous Singing Revolution, one of the most popular songs contained a call to "stop Lasnamäe!," illustrating how even then this neighborhood of Tallinn was equated to a strong Russian presence and the potential threats that Estonian

\footnotetext{
133 "Patriarch Kirill Begins a Primatial Visit to Estonia," The Russian Orthodox Church: Department for External Church Relations, June 14, 2013, accessed September 10, 2014, https://mospat.ru/en/2013/06/14/news87460/

${ }^{134}$ Russkiy Mir Foundation, “Monument to Patriarch Alexy II Unveiled in Tallinn,” September 10, 2012, accessed September 10, 2014, http://www.russkiymir.ru/en/news/129780/. Estonian Public Broadcasting, “Church Monument Unveiling Attracts Thousands," September 10, 2012, accessed September 10, 2014 , http://news.err.ee/v/society/ca90d249-c858-444f-b41f-1ac2fa440103

${ }^{135}$ For a more detailed look at Patriarch Alexy and the ways in which he worked to secure better opportunities, benefits, and respect for the ROC within Russia, see John Garrard and Carol Garrard's book Russian Orthodoxy Resurgent.
} 
patriots believed came with it. ${ }^{136}$ The construction of an Orthodox church in this district was a sensible decision, considering the large number of Russian residents. However, the construction of the religious building often led to predictably political disputes.

Throughout the long building process, the funding for the church was often called into question or criticized. It was reported that in 2010 alone, the Moscow Patriarchate gave 1.24 million Euros to the construction of this church. ${ }^{137}$ Savisaar's official visits to Moscow to discuss funding for the project with his business connections there also drew criticism from the Estonian press which questioned his loyalty and whether the project was more in line with the needs of Estonia or the desires of neighboring Russia. Although the mayor claimed that donations from individuals within Estonia were increasing and funding a significant portion of the project (which simultaneously served as validation that the church was not solely a Moscow pursuit), his own past association with illegal monetary contributions from Russia cast doubt on his word. ${ }^{138}$ Much of the money coming from the Moscow Patriarchate was linked with Savisaar's lucrative business contacts such as Vladimir Yakunin, a Russian railroad tycoon and close associate of Putin. ${ }^{139}$ Additionally, Savisaar's invitations to prominent Russian businessmen to take part in dedications throughout the church's construction have raised eyebrows among Estonian leaders. However, despite inviting Russian executives and Estonian government ministers to the dedication of Patriarch Alexy's bust, representatives from neither group attended or participated. ${ }^{140}$ Articles regarding the Lasnamäe church throughout its construction process never failed to point to at least one of the following: a connection to Russia, the ethnic

\footnotetext{
${ }^{136}$ Kaisa Kaer, “Lasnamäe - the Final Frontier?” Estonian Public Broadcasting, June, 26, 2014, accessed September 10, 2014, http://news.err.ee/v/features/b24834ad-ec9a-45cf-8b16-4357e4492255.

${ }^{137}$ Sulev Vedler, “Moscow's Spin Machine in Estonia,” RE:Baltica, March 20, 2012, accessed September 17, 2014 ,

http://www.rebaltica.lv/en/investigations/money_from_russia/a/608/moscow's_spin_machine_in_estonia_.ht $\mathrm{ml}$

${ }^{138}$ Ingrid Teesalu, "Savisaar: Lasnamäe Orthodox Church Will Be Ready By Deadline," Estonian Public Broadcasting, June 27, 2012, accessed September 11, 2014, http://news.err.ee/v/varia/9bcac2c0-42cc-46d8a52a-0e4030775f16

139 Sulev Vedler, "Moscow's Spin Machine in Estonia," http://www.rebaltica.lv/en/investigations/money_from_russia/a/608/moscow's_spin_machine_in_estonia_.ht $\mathrm{ml}$

${ }^{140}$ Estonian Public Broadcasting, "Church Monument Unveiling Attracts Thousands," September 10, 2012 , accessed September 10, 2014, http://news.err.ee/v/society/ca90d249-c858-444f-b41f-1ac2fa440103
} 
Russian minority population, or Savisaar and his own questionable political past. These are inescapable elements of any press report regarding this particular church and show the prejudice and uneasiness that the press and possibly Estonians as a whole felt, and may still feel, towards this church, fearing it as a means to further tie Russian residents to a large neighboring state.

An interesting facet of the Lasnamäe development revealed itself in an interview with a priest from the EOC-MP. He had also noticed the critical reporting over the years of the church's construction. Yet, the people of the district and Russians throughout Estonia continued to support its construction, both verbally and financially. Thousands attended the blessing of the church by Patriarch Kirill in 2013 and droves also attended the dedication of Patriarch Alexy's bust, many coming forward to revere the bust with clearly emotional countenances. These heartfelt displays and unflagging support are a testament, the priest said, to how the Russians living in Estonia view their church. "The church is not just a religious institution, but it is a symbol, a symbol of human dignity." ${ }^{141}$ The building and completion of the Lasnamäe church was an example, a symbol through which this human dignity was realized. The tone and gravity with which the priest spoke of this church's completion sounded as if he equated its construction to that of a victory. For the EOC-MP community, the church had become a microcosm of the "us-vs.-them" conflict, dividing the ethnic Russians from the larger Estonian society. By phrasing it as a victory for human dignity, the Russian community takes on the role of the oppressed and the Estonian majority as the oppressor.

The Lasnamäe church became more than simply a church, morphing into a political statement on identity and membership within Estonian society. In turn, during my own visits to Orthodox services while in Tallinn, I noticed that the churches themselves were never particularly full. Attendants were often older Russian women, providing further proof to the adage that the Orthodox Church is kept alive by faithful grandmothers. Participants would duck in and out, rarely staying for the entire service. What I observed further attests to the strength of the cultural Orthodox element over resounding faith. The multitude of people who flock to these religious dedications and support the building of new churches

\footnotetext{
${ }^{141}$ Igor Prekup, in interview with author, June 4, 2014.
} 
within Estonia shows that these structures themselves become symbols and tools in the battle to uphold the minority's Russian identity. Their construction is politicized, but once completed, the fervor with which they were previously supported does not translate into continued devotion and frequent visits. Listening to the priest talk about the Lasnamäe church, I perceived a sense of community among Russians, cultivated through the shared Orthodox faith, but with a component that was directly oppositional to the Estonians. Juxtaposed with these remarks are those of an Estonian interviewee, who questioned whether there was any conscious presence of human dignity within the EOC-MP at all, especially with its connection to the ROC. "Look at the statistics that indicate any kind of moral issues," he said, "and you will get really horrified. Because you say, if everyone is a member of this church, how can this be that a country [referring to Russia] is as corrupted as it is. ${ }^{142}$ It is this stereotype that the EOC-MP must battle against due to its connection with Russia, and that connection is the very reason why many of their more visible actions launch the church into a politicized realm, mirroring the highly polarized divide between Estonia's two main nationalities, rather than one of discussion, mutual acknowledgement, and acceptance.

Dividing the religious from the political in the case of the Orthodox Church is a difficult task. Often, the ambitions and desires of the EOC-MP are perceived as compatible with those of the Russian state, whether or not in reality such synergy exists. In the words of an EAOC priest, "the Moscow Patriarchate doesn't realize that Estonia's a free country. Or they don't want to realize that one area." ${ }^{143}$ His statement perhaps sounds prejudiced, a product of his own negative judgment of a competing church, but he is not alone. Two Estonian political scientists, Piret Ehin and Andres Kasekamp, believe that the early Russian administrations of Yeltsin and Putin operated with the aim of restoring regional hegemony in the area that was once the Soviet Union. ${ }^{144}$ The commitment and the cultivation of deeper cooperation with the ROC "suggest that the Church and [Putin] share a political culture that makes them challenge the independence of the countries that were

\footnotetext{
${ }^{142}$ Eerik Jõks, in interview with author, June 2, 2014.

${ }^{143}$ Aivar Sarapik, in interview with author, June 3, 2014.

${ }^{144}$ Richters, The Post-Soviet Russian Orthodox Church: Politics, Culture and Greater Russia, 91.
} 
under Moscow's control until 1991."145 The EOC-MP thus becomes a suspect institution for many Estonians, which only perpetuates the societal and political division.

The politicized nature of the ROC in turn lends a more political character to its subordinate church in Estonia. Ringo Ringvee noted that though the first message of the Moscow Patriarchate's official visits to Estonia is typically one of goodwill and a reiteration of its respect for or connection to the country, it is typically followed by one which effectively states "that the historical injustice [indicating the property contestation] should be managed." 146 The process is a slow moving one and therefore can be expected to be a central factor in the relationship and approach of these churches continuing forward. Father Toomas humorously remarked at the speed with which the Orthodox churches move, pointing to how only recently relations with the Catholic Church have become more brotherly and open. ${ }^{147}$ So too in 2010 did the ROC's Department for External Church Relations chairman, Metropolitan Hilarion of Volokolamsk, make reference to the Estonian property disputes in a press conference. While the Metropolitan stated that the ROC was happy with the progress that the 2002 resolution brought to the situation, eight years later, the same overarching property problem remains. ${ }^{148}$

A recent article in the World Affairs Journal looking at the state of Russians in Estonia constructed a clear link between the flagging enthusiasm for democracy, the rise of Putin, and the growing enthusiasm for the Orthodox Church, both in Russia and the near abroad. As Russia becomes more isolated on the world stage, more Russians have taken to displaying religious elements of Russian culture, sporting cross necklaces and St. George ribbons, visible declarations of their heritage, pride, and support for the church and its state. "By itself, there is nothing wrong with such religious beliefs and practices, but in the context of Russia, where the church has for ages been a political instrument of state power,

\footnotetext{
145 Ibid.

${ }^{146}$ Ringo Ringvee, in interview with author, June 3, 2014.

${ }^{147}$ Archpriest Toomas Hirvoja, in interview with author, June 3, 2014.

${ }^{148}$ The Department for External Church Relations of the Moscow Patriarchate, Metropolitan Hilarion: We hope the Patriarchate of Constantinople and the Estonian State will make further steps to normalize situation of the Estonian Orthodox Church of the Moscow Patriarchate, accessed September 9, 2014, https://mospat.ru/en/2010/11/28/news31391/.
} 
religious expression is often fundamentalist and exclusionary. ${ }^{\prime 149}$ In light of this, however, it is only fair to note that the EAOC certainly has its share of politically mobilizing moments. Though it is currently on the preferable side of the property dispute, the reinstatement of the church itself is a reflection of the political climate of that time. As Estonia was moving towards independence, the appeal of expressing cultural pride through religious means grew among Estonians who claimed Orthodoxy. National independence led to cries for church autonomy and a greater desire to manage the Estonian churches by Estonians. ${ }^{150}$ For many, the reasoning was simple: it was an easier task to become a more independently Estonian church under the Ecumenical Patriarch than under the Moscow Patriarchate, considering the historical and political divisions at the time. ${ }^{151}$ During the independence movement, the churches were already politicized and have only remained so.

The EOC-MP definitely serves the interests of the Russians who comprise its congregations. Its intersection with the political sphere is clear through its support from Estonia's Centre Party as well as its willingness to follow the policy line of its mother church, the ROC. Due to its high Russian composition, the church is one of the main advocates for the Russian minority in Estonia, in addition to being an institution that helps to preserve that particular identity and cultural awareness. This manifests itself politically due to Russia's own pledge to employ the "tool" of soft power through the maintenance of Russian heritage and language worldwide. Additionally, the EOC-MP appears to be a legitimizing institution for the Russian minority. Orthodoxy's strong presence in Estonia and the surrounding region give Russians an institution around which to rally. They mutually reinforce each other-the church speaks on behalf of the minority that it serves and so that minority flocks to it, seeking its guidance, community, and defense during times of political division or disruption.

\footnotetext{
${ }^{149}$ Katja Kort, “The Russians of Estonia: Twenty Years Later,” World Affairs Journal, July/August 2014, accessed August 2, 2014, http://www.worldaffairsjournal.org/article/russians-estonia-twenty-years-after ${ }^{150}$ Aivar Sarapik, in interview with author, June 3, 2014.

${ }^{151}$ Archpriest Toomas Hirvoja, in interview with author, June 3, 2014.
} 


\subsection{Media and the Minority}

The prevalent role of media and its influence on how conflicts and groups are viewed is an inescapable reality of our technologically savvy world. The EAOC and EOC-MP are no exception, each using various media avenues to reach their members and project their message further. As Aivar Sarapik said in our interview, "it's very normal that you use the language not only for praying but you use it for missionary work and informing your parish and other people." 152 The strength of media in today's world thus warrants separate attention in that it plays a role in defining the identity of the Russian minority in Estonia and determining the extent of its strength.

Although the topic of media was not included in the original interview questions, remarks on the subject managed to find their way into responses unsolicited. During interviews, it became a topic that naturally wound its way into each individual's transcript, whether in regard to Russian identity, Russia's compatriot policy, Estonian integration, or the perpetuation of Orthodox culture. So often did it make an appearance that excluding it from this analysis would seem to be disregarding an interesting component of the data. Therefore, this section is not an in-depth analysis of the media itself, but rather how its use is perceived, how it affects the Orthodox churches, how it impacts the minority population, the ways in which the Church may use it for its own aims, and its place in the greater integration puzzle.

Estonia boasts fairly good church-state relations. The state's liberal policies help to maintain a productive separation and positive working relationships. The ECC helps to facilitate these relationships, particularly through the funding it receives and distributes to its member churches. Overall, the two realms touch rarely, maintaining their own spaces as the Constitution prescribes. Rohtmets noted in his interview that this positive church-state relationship is sometimes offset by a slightly more critical media presence. ${ }^{153}$ In media coverage of the faith communities, Estonian reporting often draws attention to the undeserved preference that Christian churches may enjoy. Estonia is home to many other faith groups and believers who often do not receive comparable attention or representation.

\footnotetext{
${ }^{152}$ Aivar Sarapik, in interview with author, June 3, 2014.

${ }^{153}$ Priit Rohtmets, in interview with author, June 7, 2014.
} 
Though media is often critical of possible government inclination towards Christianity, I agree with Rohtmets that Estonia does a respectable job when it comes to the division of church and state, despite the occasional media criticism.

Language policy has been a pivotal issue in Estonia since it declared its independence and, along with it, named Estonian as the official language of the republic. This change left a large contingent of the population who only spoke Russian with a choice to either learn the language in order to assimilate or remain isolated from the a greater portion of Estonian society. This issue of language politics in Estonia has garnered much attention from the media, government, and international community, yet this study seeks to look at the ways in which religion has influenced identity and integration, considering how much attention has been paid to matters of language, citizenship, and education frontiers. Issues of language permeate religion, however, particularly as the means through which churches and their congregations are reached and influenced by media. In terms of Russian-language media, the overwhelming impression I encountered from ethnic Estonians was that it is invasive and seeks to undermine the Estonian state or one's loyalty to it. As a border state with Russia and home to a substantial Russian minority, it is impossible for Estonia to block the presence of Russian-language news and programming on its networks. Additionally, to do so would be unjust and violate the Estonian constitution's promises. Yet, Russian media, in the words of one interviewee, keeps Russians in Estonia "on a very short leash," in a Russian-exclusive "media room."154 Not only the news, but cultural programming as well, is labeled by many Estonians with the negative classification of "propaganda."

The First Baltic Channel (Первый Балтийский Канал, PBK) is one of the primary providers of Russian television programming in Estonia. Stemming from the Baltic Media Alliance that broadcasts television programming in Latvia and Lithuania as well, PBK has strong Russian connections. The Baltic Media Alliance itself is the most popular media company serving Russians in the Baltics, reaching 4 million viewers regularly. ${ }^{155} \mathrm{PBK}$ is not only owned entirely by Baltic Media Alliance Latvia, meaning that the decisions on

\footnotetext{
${ }^{154}$ Eerik Jõks, in interview with author, June 2, 2014.

155 “BMA Infographic,” Re:Baltica, accessed September 17, 2014, http://www.rebaltica.lv/en/investigations/money_from_russia/pbk_infographic
} 
programming come from Riga, but it also works closely with the Centre Party in Estonia. It produces the Centre Party's campaign advertising and is headed by the organization's supporters. ${ }^{156}$ This channel and the greater network of which it is apart of often re-telecast Russian programming, filling in an entertainment gap that many Estonian channels do not provide to Russian viewers. Combined with their willingness to work with Russian oligarchs and Russian-affiliated politicians and parties, the question often arises as to whether these channels are simply conducting business or furthering the Russian Federation's soft power agenda abroad. ${ }^{157}$ Orthodox programming is provided over these channels, as well as Russian radio channels. Ringvee attests that "their media presence is quite visible" especially "in [the] northeast of Estonia," closer to the Russian border. ${ }^{158}$ In filling Russians' desire for understandable media, they also perpetuate the Russian Federation's soft power agenda and further cultivate a resistance towards Estonian language learning. ${ }^{159}$ "They are keeping them together within this language room because it's much easier to manipulate. That's my personal view...not even a view but my experience," proclaimed one interviewee. ${ }^{160}$

The ties between Russia and Estonian-Russian media are truly strong and provoke understandable cause for alarm among those who fear the development of a disloyal Russian minority. For many Estonians, it is unsettling to observe the connections between the EOC-MP, Russian media, and the Russian oligarchs and politicians that fund and direct

\footnotetext{
${ }^{156}$ An interesting addition to this deferment to Riga was this statement by Oleg Samorodnij, former correspondentg for Komsomolskaja Pravda, featured in the Re:Baltica article, "Who is the puppet and who is the master?" The article did not claim to be able to validate whether this claim was correct or not, but it's worth noting from a former insider. "I don't believe that decisions are made by PBK Estonia and I don't believe that decisions are made by BMA in Riga either. I think that decisions are being made in Moscow." ${ }^{157}$ Inga Springe, Sallija Benfelde, and Miks Salu, "The Unknown Oligarch,” Re:Baltica, April 11, 2012, accessed September 17, 2014, http://www.rebaltica.lv/en/investigations/money_from_russia/a/608/moscow's_spin_machine_in_estonia_.ht $\mathrm{ml}$

${ }^{158}$ Ringo Ringvee, in interview with author, June 3, 2014.

${ }^{159}$ In addition to Russian telecasts, Russkiy Mir, a federally funded foundation established in Russia at Putin's behest to spread and strengthen Russian culture among compatriots abroad, issues grants to various NGOs in the Baltics for causes it supports. One of the disclosed benefactors of a grant in Estonia was the Human Rights Information Centre in Estonia to be used in their fight against Estonian language requirements in Russian-speaking schools. Laura Zvejniece, "A Re:Baltica Investigation: the first cross-border investigation of Russia's soft power in the Baltics," Re:Baltica, accessed September 17, 2014, http://www.rebaltica.lv/en/investigations/money_from_russia

${ }^{160}$ Eerik Jõks, in interview with author, June 2, 2014.
} 
its programming. In light of Russia's recent increased hostility towards its near abroad, the Baltic states have come to view the Russian media outlets as a larger threat than they once did. Latvia has charged Russia with working to undermine national authority through media outlets and Lithuania suspended PBK programming in the fall of 2013 for controversial material. Estonia has yet to ban broadcasting out of fear of inciting freedom of speech and press debates, though journalists have called for the EU to address this issue instead of leaving it to each individual country. ${ }^{161}$ The question of how to deal with Russian propaganda while not isolating the Russian minority by cutting off the programming it consumes is a key issue for Estonian political leadership today. The 2011 Praxis report on Integration Monitoring in Estonia stressed the need to "support the activities of information channels, including Russian Internet portals, that disseminate, in a reliable manner, daily practical information...regarding people's everyday lives, health, security [and] cultural events" in order to foster greater trust and cooperation within the Estonian state. ${ }^{162}$ It is especially important, the report notes, "in the light of Russia's compatriot policy — which is damaging to Estonian integration processes." 163

The prevailing negative perception of Russian media in Estonia can be tempered by the findings and suggestions of this Integration Report however. Russians are increasing their participation in and consumption of Estonian media, ironically diversifying their pool of media sources to a greater extent than most ethnic Estonians. Also, ethnic Russians consuming their news in their mother tongue are not necessarily getting it directly from Russia or its affiliate networks. Many are instead seeking global providers and international programming that comes equipped with Russian subtitles. ${ }^{164}$ While the media primarily marks a line of division between the two major national groups in Estonia, there is hope for a shift in that trend, despite Russia's current political trajectory. Praxis found that "prejudiced, offensive and arrogant attitudes towards other ethnicities...shown in both Estonian and Russian media magnifies the impression of the acuteness of ethnic conflicts in

\footnotetext{
${ }^{161}$ The Baltic Times, "Baltics continue discussions to counter Russian propaganda TV," April 21, 2014, accessed September 27, 2014, http:/www.baltictimes.com/news/articles/34743/\#.VDWQ0EsmdMF

${ }_{162}$ Estonian Integration Monitoring Summary 2011, 20

163 Ibid.

${ }^{164}$ Ibid.
} 
Estonia, while there are not many conflicts in contacts outside the media." ${ }^{\prime 16}$ These findings connect with the hopes of an EOC-MP priest, who voiced his concerns over the bitterness that the media incites. The less the people rely on the church, the more they depend on the media, and vice versa, he said. ${ }^{166}$ Fostering a greater faith community, rather than a political or cultural club would serve the Russian population more and perhaps limit its consumption of media that aims to prevent their integration.

\subsection{Integration}

Integration has been a major focus in Estonia since it regained its independence in 1991. The discussion on integration appears to be at the root of most of Estonia's key debates - citizenship, language policy, education, labor, media, politics and civil society. With a quarter of the population being Russian or Russian-speaking, the need for integration policy has been present from the beginning. Every couple of years, new integration reports, modules, and proposals are introduced, implemented and assessed. As the years have gone by, new fields of assessment are taken into account as the demographic picture of Estonia and the levels with which its minority populations are integrated become increasingly clear. This most recent report examined markers of linguistic, legal and political integration among non-Estonian ethnic groups. Overall categories of integration were dictated by citizenship status, whether the individual considered Estonia to be one's homeland, whether the individual viewed oneself as a part of the people embraced by the constitution, and by their level of proficiency in Estonian. ${ }^{167}$ Initially, however, focused attention to the process and an in-depth understanding about the way in which Russianspeakers integrated themselves into society were not a political priority. "For the newly restored Republic of Estonia, the main problem was not the real integration of the Russian speaking population, but regulation of their legal status and social position, which was done [primarily] through the Citizenship Act, the Aliens Act, and the Language Act."168 Therefore, the greatest concentration was placed on language acquisition as a key to

\footnotetext{
165 Ibid.

${ }^{166}$ Archpriest Toomas Hirvoja, in interview with author, June 6, 2014.

${ }^{167}$ Estonian Integration Monitoring Summary 2011, 8.

${ }^{168}$ Ibid, 24.
} 
naturalization, in order to reduce the "threat" of such large numbers of non-Estonians within the nation's borders. ${ }^{169}$

The integration programs changed as Estonia looked towards European Union accession. Minority issues in this small Baltic republic were one of the main areas that the EU deemed as essential to address. Standards were adjusted and a new motivation fueled the drive towards integration. Primary focus was given to easily measured, surface criteria such as "reducing the number of people with undetermined citizenship [and] adapting language skill requirement to EU norms." ${ }^{170}$ However, the rush to join the EU constituted a patchwork approach to integration, one that ignored social and civil cohesion, education, and cross-cultural exchange among the population. Minority groups banded together against the integration policy rather than assimilate with the greater Estonian society. Following the achievement of joining the EU, but in light of the continued problems between minority and majority populations, integration policy has shifted to a more detailed focus on truly incorporating minority members into Estonian society and helping to carve out a sense of belonging and identification around Estonia as their home. While the numbers of those survey respondents who identify Estonia as their only homeland have grown, even among those living in Estonia who possess Russian citizenship, integration still has a long way to go. ${ }^{171}$ Alongside small victories have been increasingly polarized attitudes towards integration, undoubtedly mirroring the polarized political situation between Russia and the West. The fear and hostility with which Estonians look towards Russia is understandable; $19 \%$ of youth between the ages of 15 and 19 have chosen not to pursue Estonian citizenship despite being born, raised and educated there, while 12\% indicated a preference for Russian citizenship. ${ }^{172}$ Analysts indicate that a key to integration success is to engage minorities as participants and benefactors of the policies, rather than simply objects of a political agenda. ${ }^{173}$

\footnotetext{
${ }^{169}$ Kuus, "European Integration in Identity Narratives in Estonia: A Quest for Security," 95. Feldman, "Culture, State and Security in Europe: The Case of Citizenship and Integration Policy in Estonia," 680.

${ }^{170}$ Estonian Integration Monitoring Summary 2011, 24.

${ }^{171}$ Ibid, 7.

172 Ibid, 16.

${ }^{173}$ Ibid, 25.
} 
It is believed that churches can assist in the integration effort, particularly through cultivating an environment that is open to fraternal cooperation while still maintaining a strong sense of cultural identity. However, this study's interviewees expressed their doubts over churches' actual ability to assist in integration measures. Take for example Ringo Ringvee's view:

"It's kind of a slogan often for religious communities or associations to [say] they help integration. But it seems that, and this doesn't only apply to the Moscow Patriarchate or the Orthodox Church of the Moscow Patriarchate here, but it seems that these associations, or these religious organizations that have a very close connection to the ethnic identity, they are more interested in keeping this ethnic identity than in integrating these people into the rest of society. I think this has nothing to do with Estonia, but in many ways it's politically correct for religious communities to help integrate, but it seems that much more helpful for integration are those religious associations that are international and global.",174

Working within the Ministry of the Interior, he sees the constant competition for superiority between ethnic identity and overall integration. This assumption that religion aids integration is, in his opinion, a "naïve" one. Another interviewee working for an ecumenical organization shared a similar opinion. In regards to the EOC-MP, he sees the link between the church and Russia as too strong, occupying the primary role, leaving allegiance to Estonia a secondary priority. Not only does the Russian government have a stake in the matter, considering the Estonian church's close relationship with its mother church, the ROC, but the ROC too has its own aims for the EOC-MP; it seeks a strong relationship in hopes of maintaining its position as largest Orthodox church on the European continent. In order to maintain this dominance-and the numbers and support that fuel it - members must remain un-integrated. When someone is integrated, says Eerik Jõks, they begin seeking out answers that the ROC and Russia may not prefer to answer. ${ }^{175}$ Both arrived at a shared question: Can the Church even have a noticeable role in integration and shaping the political and cultural identities of this minority, when so few of them pass through the church's doors each week?

\footnotetext{
${ }^{174}$ Ringo Ringvee, in interview with author, June 3, 2014.

${ }^{175}$ Eerik Jõks, in interview with author, June 2, 2014.
} 
Based upon the integration plans of Estonia and the themes that arose most often through my own interviews and research, I've identified four areas into which elements of this integration discussion and the church's overlapping role or impact are noteworthy: culture, language, history, and definition debates (integration versus assimilation versus segregation). By briefly investigating the way in which Orthodoxy affects each of these facets, I not only hope to provide a more detailed look at part of a larger issue, but also discern an answer to one of this thesis' key questions: whether the church helps or hinders its minority members in integration pursuits.

\subsubsection{Culture}

The multitude of people present at public Orthodox celebrations or church dedications, such as in Lasnamäe, is a testament to the strength of the cultural side of the Orthodox Church and its prevailing strength over actual faith. The stark contrast between these more public organized gatherings and the typical Sunday liturgy crowd give the impression of a culture of belonging, rather than believing. In the case of the EOC-MP, times when such great numbers are gathered are viewed in the press as events synonymous with Russian solidarity and assertion of one's ethnic heritage. While many Orthodox believers and outsiders alike link ethnicity and faith as a package deal, this connection is one that many priests in the EOC-MP are seeking to battle. The perception that the EOC-MP is a Russian church, a foreign church, often perceived as similar to a squatter on Estonian soil, is detrimental to the church's reputation as a whole and its ability to positively affect integration among its parishioners. Father Toomas assured me that he did not feel as though he was in a Russian church, when asked what it was like to be an Estonian in the EOC-MP. He inserted a gentle reminder of the EOC-MP's autonomous status, but also assured me that he sees the EOC-MP as Estonian. "It's the local church, and it's not important which ethnos or which language we have. Nowadays, the world is open.... and so for me, the ethnic is not the most important thing. For me, it's... [about being] close to Christ." "176 An

\footnotetext{
${ }^{176}$ Archpriest Toomas Hirvoja, in interview with author, June 6, 2014.
} 
acceptance of this viewpoint over the ethnicity-centered one that predominates in public opinion would be beneficial to both Orthodox churches in Estonia and their mutual relations.

Another component of the cultural aspect of integration relates to how Estonian culture is marketed or presented to those who are not ethnically Estonian. Due to Estonia's long history of external domination, Estonian culture has existed much longer than the actual Estonian republic. Typically centered on the incredibly unique Estonian language, Estonian identity leans heavily on the ethno-linguistic aspects of its culture over those of a state or republican identity. One interviewee called for a purposeful shift towards to a state-based culture to improve the progress of integration. Such a change would stress the statehood of Estonia, while allowing ethnic groups to keep the elements of their culture alive and not feel like their language and customs are in direct competition with Estonian culture and language, as they often do when the focus of integration is placed on language acquisition. ${ }^{177}$ The Integration Monitoring Report confirms this view. In a day and age when minorities feel more empowered to speak up and protest, especially among the younger demographic, education in Estonian that then focuses on simply memorizing "terms and themes" significant to Estonian history and national identity "might become perfunctory and give rise to protest and distrust among pupils." ${ }^{178}$ Instead, education about the Estonian republic should focus on cultivating dialogue among citizens in the languages that they are best able to express themselves, and take into consideration the critical perspectives non-integrated or partially integrated members of society may have. The integration study refers to this as "civic education" and considering that the Church is often looked to as a cultivator of civil society, secular and religious interests intersect here.

Since the EOC-MP lays claim to the majority of Orthodox believers of Russian heritage, it has the opportunity to create a positive middle-ground of Estonian and Russian culture. Integration evaluations claim that consideration should be given to how Estonian culture and language are presented to semi or un-integrated Russians, as many of them, "due to limited contacts with ethnic Estonians, lack of trust, narrow educational attitudes

\footnotetext{
${ }^{177}$ Priit Rothmets, in interview with author, June 7, 2014.

${ }^{178}$ Estonian Integration Monitoring Summary 2011, 11.
} 
and Russian-oriented media preferences" may have negative impressions of Estonian culture and the prospect of integration. ${ }^{179}$ If the EOC-MP were to truly embrace its status as a local church and encourage its Russian parishioners in both Estonian and Russian cultural pursuits, its role in integration could be improved. Much relies on the Moscow Patriarchate as well, in addition to the local EOC-MP churches. The EAOC's Ecumenical Patriarch recently canonized eleven Estonian saints in 2012, all of whom had been martyred during the period of Soviet occupation. ${ }^{180}$ The ROC has numerous Estonian saints and has been adding to its registry new martyrs who were condemned to death by the communist regime. However, the Ecumenical Patriarch's canonization of eleven Estonians speaks to his heightened awareness of the importance of acknowledging Estonian culture in comparison to the Moscow Patriarch. Acknowledgment, respect and alignment with Estonia as a state and its civic culture would greatly benefit the ROC and the EOC-MP in opening the door to a more cordial relationship with ethnic Estonians.

\subsubsection{History}

Any reticence that the EOC-MP may have in assisting the integration agenda of the Estonian state generally comes from its continuing status as a tenant church. All of my accumulated evidence drawn from personal interviews, public statements made by the ROC or EOC-MP regarding the church's status in Estonia, and existing scholarship on the Orthodox Church in Estonia acknowledges the property disputes of the 1990s and early 2000s as a continuing influential factor on the way the church views the state and the way Russians view the Estonian government. At present, according to the agreement made in 2002, the EOC-MP rents their church buildings from the state. This arrangement preserves a sense of bitterness, serves as a reminder of the past, and subjects the EOC-MP to a secondary status in the ranking of Orthodox churches in Estonia. This stipulation regarding property ownership is not objectionable due to high rents from the state, which are low and are intended to keep the EAOC from regulating the rent of a church that it refuses to

\footnotetext{
179 Ibid.

${ }^{180}$ Estonian Public Broadcasting, “Orthodox Church Canonizes 11 Estonian Martyrs,” May 17, 2012, accessed September 22, 2014, http://news.err.ee/v/culture/07cc3831-4d86-40ad-be5e-ced39487b14d It is worth noting that five of those eleven were ethnically Russian, though residing in Estonia.
} 
acknowledge in principle. Instead, the primary annoyance is in the fact that the EOC-MP cannot rent and manage its own properties, lands, and assets. In comparison, the EAOC, which acquired the property of all 80 church parishes that existed in Estonia after independence, the EOC-MP has limited resources with which to create income for the church. $^{181}$

An Orthodox priest of the EOC-MP spoke about how a church's new school facilities had to be rented first from the Roman Catholic Church and then, the following year, from an entirely new group with a larger building. Changing locations every year is a less than ideal situation, but is mandated by the fact that the church lacks the necessary facilities on its own. The weight of this decision to restitute property solely to the EAOC cultivates a sense of frustration among the EOC-MP clergy and laity. The same priest mentioned his church's desire to set up a translation house for Orthodox literature before quickly acknowledging the unlikelihood of this endeavor ever happening considering the church's financial standing. Other churches benefit from their land holdings, and not simply just from the buildings on them, which they can rent, but are able to profit from harvesting the land's natural materials. ${ }^{182}$ EOC-MP churches depend primarily on the small amount of funding siphoned through to members of the ECC and the donations they gain from candle purchases and church tithing. This has been the state of affairs since the early 1990s. Though recent, this detrimental chapter from the history of the new Estonian republic remains highly symbolic and present in the minds of Russian Orthodox living in Estonia.

History affects both sides of this memory. Not only does the EAOC cite the institution of the Stockholm Synod as the rightful continuation of its church, a point that has never been canonically recognized by the ROC or EOC-MP, but it also holds fast to a belief that the ROC aided the Soviet state's russification efforts. Geographer Dimitrii Sidorov looked into this claim by evaluating the primary languages of churches that were closed during the Soviet occupation years of 1944 to the 1960s. During that period, 62 churches were closed and of them 57 were Estonian-speaking. ${ }^{183}$ In my interview with a priest of the Moscow

\footnotetext{
${ }^{181}$ Richters, The Post-Soviet Russian Orthodox Church: Politics, Culture and Greater Russia, 78.

182 Archpriest Toomas Hirvoja, in interview with author, June 6, 2014.

${ }^{183}$ Dmitrii Sidorov, Orthodoxy and Difference: Essays on the Geography of Russian Orthodox Church(es) in the $20^{\text {th }}$ Century (San Jose: Pickwick Publications, 2001), 132.
} 
Patriarchate-affiliated church, he acknowledged the shift from a strong Estonian Orthodox base to a primarily Russian one once the Soviet occupation set in. "Some Soviet people came... and some families of the military men, some from the working class, to build the factories and new districts. Some of them were religious people from the Soviet Union and they started to join the congregations and...Estonians started to fade away." "184 Eventually, the demographic of the congregations dictated a shift from an Estonian liturgy to a primarily Slavonic one. Though the former ROC Patriarch, Alexy II, championed the church as a main protector of Estonian Orthodoxy, Sidorov's findings and the decline in Estonian participation have led scholars to conclude that the Orthodox faithful in Estonia whom the ROC was most intent to protect were those of Russian descent. Richters elaborates that such an interpretation not only acts as evidence of Alexy's decision to use "his authority to advance the communist policy of russifying the non-Russian republics," but that "ethnic Estonians abandoned the ROC after World War II because they perceived it as an ally of the occupiers.","185

Estonia's implementation strategy for the state integration plan of 2011-2013 lists among its general priorities the development of citizens' associations "in order to increase the participation of people whose mother tongue is other than Estonian in the civil society; in order to involve people whose mother tongue is other than Estonian more efficiently in social life."186 The Orthodox churches in Estonia have great potential to take on that role, cultivating cross-cultural fraternal relationships beginning with the churches themselves, taking advantage of their status as being the largest denomination (when combined) within Estonian Christianity. However, their historical disputes that still remain largely unresolved appear to be the largest obstacle standing in their way in the pursuit of such potentially fruitful integrative measures. The inability to escape mention of the property disputes in any conversation related to Orthodoxy in Estonia is a testament to the necessity of the repair and resolution of this matter in order to rid those loyal to the EAOC of their view of the EOC-MP as an occupation church and the EOC-MP from viewing the EAOC as an unChristian vindictive landholder. As one of my interviewees put it, the cycle of ignoring and

\footnotetext{
${ }^{184}$ Archpriest Toomas Hirvoja, in interview with author, June 6, 2014.

${ }^{185}$ Richters, The Post-Soviet Russian Orthodox Church: Politics, Culture and Greater Russia, 79.

${ }^{186}$ Estonian Integration Strategy 2008-2013, Implementation Plan for 2011-2013, 5.
} 
refusing to recognize one another could continue on indefinitely; "if somebody is not saying to you 'hello,' you don't need to say 'hello' back.,"187

\subsubsection{Integration vs. Assimilation vs. Segregation}

While the churches could help to integrate non-Estonian speaking members into society, the EOC-MP's branding as an outside church prevents it from being an effective institution for such ends. Rather, the debate between the two Orthodox churches is reduced to whether the EOC-MP will assimilate with the set expectations of the Estonian state and majority, which comes with the expectation of a renouncement of property claims and any connection with Russia, or to be segregated from Estonian culture and civil society, further instilling its reputation of a solely Russian institution, instead of an Estonian one that is autonomous from the Moscow Patriarchate in Russia. For obvious reasons, both sides are unrelenting in their views on this issue and stand resolute, preventing any compromise so far. This conflict between the churches appears to foster the attitude that integration planners have cautioned against - the fulfillment and reinforcement of negative stereotypes of ethnic Estonians in the eyes of non-Estonian youth that their older generations may be fostering at home.

The tensions and contradictions between integration, assimilation and segregation were addressed directly by an Orthodox priest in one of my interviews. Having served in the EOC-MP diocese, and neither Estonian nor Russian by birth, he thwarted my question regarding the Church's role in integration by dismissing the option of integration immediately. The word was of no import. It had no bearing on the reality of the present

circumstances because it was not an honest goal or consideration in the state's agenda. ${ }^{188}$ To be integrated means to bring into equal participation, to merge two groups into a single membership. In this situation, he believed that the Estonian state expected an overblown confession and apology by the EOC-MP, a self-declaration to have been an instrument of Soviet influence and occupation, one that it would never provide due to pride, culture, or canonical principle. As a result of its unwillingness to accept this alternative interpretation

\footnotetext{
${ }^{187}$ Aivar Sarapik, in interview with author, June 3, 2014.

${ }^{188}$ Igor Prekup, in interview with author, June 4, 2014.
} 
of its past, the EOC-MP has therefore been segregated from society. Although included in the ECC, its secondary status to the EAOC outside of the Council resulting from defeats suffered in the post-Soviet name registration battle and property redistribution have left its faithful feeling as if they were unwanted outsiders in Estonia. The accusations of being more loyal to Moscow than to Estonia have resulted in cultural and political resentments and defensive nationalism.

In a follow-up interview with another subject, with my interest piqued by this new perspective, I followed the initial question on the integration-aiding measures of the churches with this commentary, hoping to solicit a response to the theory that integration is not a true option for Orthodox Russians in Estonia. The interviewee, though not a member of either Orthodox community or a clergyman of any other denomination, bristled at the question. Next, he cautioned me against those who would rephrase the issue in such terms, indicating that their intentions were most likely deceptive. ${ }^{189}$ I found this advice interesting and thought-provoking, though I could not entirely agree. Each side certainly feels attacked by the other, but it is precisely this refusal to acknowledge the other's perspective, to suspect ulterior motives in all their words, that has prevented each church and those committed to them from moving forward over the past decade. In turn, by refusing to address the pressure Russians and its members in the EOC-MP may feel in adapting their narrative and identity to the interests of the Estonian state, new generations of individuals reticent to genuine integration are being formed.

\subsubsection{Language}

The main debate underlying all integration discourse in Estonia revolves around the issue of language. Much scholarship has been devoted to the politics of language in small states seeking to assert their national identity. Recently, Estonia's particular situation has gained increased media attention due to the Russian annexation of Crimea and support of Russian separatists in eastern Ukraine. Putin's use of the treatment of Russians living in Ukraine as one of his key justifications for involvement struck Estonia as especially

\footnotetext{
${ }^{189}$ Eerik Jõks, in interview with author, June 2, 2014.
} 
threatening, having heard similar arguments for strong compatriot abroad policy in Estonia and calls for the lessening of Estonian state requirements on non-Estonian citizens and aliens. Language policy has garnered the bulk of the attention as the Kremlin has spoken out about a perceived attack on the Russian language, particularly in the schools. The Basic Schools and Upper Secondary Schools Act was approved in 1993 by the Estonian state and began the process of transitioning all state-funded public schools towards a $60 \%$ minimum of Estonian instruction. The remaining percentage can be taught in whatever target language the school prefers. ${ }^{190}$ Transition planning began in 1997 and actual transition began ten years later, with hopes of full integration forecasted for approximately four years down the road. Due to the state-funded nature of these public schools and the need to enforce this act, the National Language Inspectorate has taken to testing teachers and other employees of the state on their Estonian language skills. The testing and monitoring is within the rights of the state and its laws, but has given rise to hostile criticism whose representatives argue that the state's action is discriminatory in nature, particularly because of the corresponding ability of those inspectors to deem teachers and other state employees unqualified for their jobs and force their termination. ${ }^{191}$ At the same time however, it seems improbable that teachers whose own linguistic capabilities are below those of the standards they are supposed to impart to their students can fulfill their teaching responsibilities. ${ }^{192}$ In places such as the city of Narva, a predominantly Russian-language centered community on the eastern border of Estonia, the work of such inspectors and the prescriptions of the Act are perceived as discriminatory against the Russian language, and by default, the Russian culture. $^{193}$

\footnotetext{
${ }^{190}$ Basic Schools and Upper Secondary Schools Act, Chpt. 3, Div. $1 \S 21.1$ (2010) https://www.riigiteataja.ee/en/eli/530102013042/consolide. Estonia's "Welcome to Estonia" webpage even has a page, published January 31 2013, that covers the topic of Estonian language instruction in Russian language schools. This indicated that the transition to the $60 \%$ standard is predicted to be complete by 2014 , the year in which children who have had the $60 \%$ of their education administered in Estonian will be graduating. http://estonia.eu/about-estonia/society/russian-language-schools-transition-to-partial-estonianlanguage-instruction-what-is-happening-and-why.html

${ }^{191}$ Clifford J. Levy, "Estonia Raises Its Pencils to Erase Russian,” New York Times, June 7 2010, accessed September 22, 2014, http://www.nytimes.com/2010/06/08/world/europe/08estonia.html. 192 Ibid.

193 "Language inquisition: Estonia gets tough on Russian speakers," Russia Today, December 12011 , accessed September 22, 2014, http://rt.com/news/estonia-russian-language-ban-635/.
} 
In the language debate, many of the previously mentioned themes come to a head. The text of the Basic School and Upper Secondary Schools Act's text speaks to the tension between a national culture based on an ethnic/cultural criteria, such as language, and a state-based culture. It states that these schools help to socialize "a new generation...based on the traditions of Estonian culture, common European values, and the recognition of the main achievements of world culture." The anticipated end result is greater integration and contribution to Estonian society. ${ }^{194}$ Although these are the stated aims, the backlash against this act by the Russian minority indicates that the theme of integration by way of language is seen as an attack on its own Russian cultural identity. This is probably because of the unique cultural circumstances that the Russian minority finds itself in. One interviewee articulated an opinion that the minority was not fully Russian, but not Estonian either. "Who are they? That's the question," he proclaimed. ${ }^{195}$ Indeed it is a large and looming question that this thesis cannot possibly answer, but the passion with which language debates have proceeded in Estonia show us that language is not only at the root of Estonian cultural identity, but Russian as well.

The interplay of assimilation, integration, and segregation also echoes in the language debates. The Russian minority perceives the state's moves towards increased Estonian language instruction, even in predominantly Russian-speaking schools, to be a forced assimilation policy rather than one of acceptance and integration. The proposals to cast Russian as a second national language are often seen as a fairer approach to integration by that minority, while Estonians balk at the suggestion. To be expected to speak the state's official language is not a requirement that typically provokes resistance. In a New York Times article, Ilmar Tomusk, the director of the Inspectorate, stated it plainly: "For a democratic society, it is quite common that public servants should know the state language. If a public official is in Russia, he must know the Russian language. If he is in Estonia, he must know Estonian. There is no discrimination." 196 However, Estonia's tumultuous history with its large neighbor to the east negates normality in the process of integration.

\footnotetext{
${ }^{194}$ Basic Schools and Upper Secondary Schools Act, Chpt. 1, § 3.3 (2010)

195 Eerik Jõks, in interview with author, June 2, 2014.

${ }^{196}$ Levy, "Estonia Raises Its Pencils to Erase Russian," New York Times, http://www.nytimes.com/2010/06/08/world/europe/08estonia.html.
} 
The Orthodox churches find themselves at play in the debate about the role of language in integration. During the Soviet era, as Estonians faded away from the Orthodox churches, the language of the inter-church communication began to shift from Estonian to Russian, though it is worth noting that all churches under the Moscow Patriarchate perform their liturgies in Church Slavonic. The trend continues until today with most EAOC churches communicating their homilies and announcements in Estonian while EOC-MP primarily conducts theirs in Russian or Church Slavonic. While taking part in an EOC-MP service, I observed token instances of Estonian being used: during the Lord's Prayer and for some prayers of intentions. However, most services are conducted in the language that best serves the congregation and in the case of the EOC-MP, that is typically Russian. Just as the historical property disputes mostly resonate in the higher levels of church and state hierarchy, so too do the language conflicts in the church originate with the leaders of the institutions.

News from Russia is often condemned by ethnic Estonians as propaganda disguised as news, taking advantage of its consumers' failure to linguistically integrate and tap into the Estonian media outlets. Such arguments are typically phrased as furthering ethnic Russians' reluctance to learn the language, thus keeping them dependent on Russian sources, which then abuse their influence. The same charge is often levied against the leaders of the EOC-MP, particularly Metropolitan Kornilii. In June 2014, shortly after I conducted my interviews in Estonia, the Metropolitan celebrated his $90^{\text {th }}$ birthday. Kornilii has ministered to the Orthodox flock in Estonia for nearly half a century, and though the son of a Russian officer, was born and raised in Tallinn. ${ }^{197}$ Kornilii was arrested by the KGB and imprisoned for religious materials and speech, making his way back to Estonia after "rehabilitation" from his labor camp experience. ${ }^{198}$ His personal history is a reminder of what many EOC-MP priests call on Estonians to remember, that regardless of ethnicity, the church as a whole suffered under Soviet rule. Like his predecessor, Alexy, Kornilii is known for speaking Estonian well. Yet, he continues to draw criticism for his failure to

\footnotetext{
${ }^{197}$ Inga-Gretel Linkgreim, “Metropoliit Kornelius tähistab 85. sünnipäeva,” ERR, June 19, 2009, accessed September 18, 2014 http://uudised.err.ee/v/vr/kultuur/9c01f0e7-3268-42b4-8df0-bad84268af76.

198 “Metropoliit Korneliuse 80. sünnipäev,” ERR, June 19, 2004, accessed September 18, 2014, http://uudised.err.ee/v/d5858df8-df06-47de-bb32-bdbf6589fd3a
} 
ardently encourage the priests within his diocese to learn the language of the country in which they are serving. "I never heard him say to his public, to Russians, to learn Estonian. That should be something quite elementary," remarked one of my interviewees. ${ }^{199}$ I received a conflicting point of view from a priest within the EOC-MP, who claimed that though the learning of Estonian was not externally proclaimed, it was an issue that the Metropolitan addressed internally among his priests. Accordingly, Kornilii is very much focused on the local church aspect, having been born, raised, educated, and ordained as a priest within Estonia himself. He encourages Russian-speaking priests to learn Estonian, but leaves it to them ultimately to decide. Within the church, there is no official mandate about language. One priest observed that those who do not learn Estonian could very well be comfortable with a Russian-only community and congregation, as he put it, a "Russian ghetto." While the Metropolitan gives the freedom to his clergy to make that choice, if priests prefer to have a greater "moral influence, spiritual influence on society" they must try to integrate and encourage their congregations along the same path. ${ }^{200}$

Language is the gateway into integration, both for the church and the state. The lack of consistently strong emphasis from the EOC-MP on Estonian language acquisition hurts its efforts to cultivate a reputation as a truly Estonian-minded church as well as an effective tool towards positive integration. The Metropolitan's personal connection and affection for Estonia is an asset to the church, but would be better utilized in formal calls to his clergymen and congregations to take strides toward a more bilingual existence in the name of better relations between Estonia's two main nationalities. The EOC-MP's inactivity in this regard and the freedom of Russian priests to decline such invitations for integration actively support the claims by the church's critics that it fosters Russian identity at the expense of civic Estonian identity and forestalls integrative processes.

\footnotetext{
${ }^{199}$ Eerik Jõks, in interview with author, June 2, 2014.

${ }^{200}$ Archpriest Toomas Hirvoja, in interview with author, June 6, 2014.
} 


\section{The Ukrainian Crisis and Its Possible Implications}

The research for this thesis took place during the escalation of Ukraine's Maidan crisis and, later on, the referendum in Crimea. The world watched as Putin annexed a portion of another state's territory, an unprecedented step in a post-World War II world. The very fact that the world simply watched angered many, especially those states that had had their independence taken from them by Russia's predecessor, the Soviet Union. Estonia was one such country. With its high population of Russian-speakers and adjacent borders, Estonia voiced concerns that similar tactics and arguments used by Putin to seize Crimea would be used against it in due time. For Estonians, the actions taken by Russia were a manifestation of the involvement that the Russian government had been verbally condoning for years through its compatriot policies. Now, in Ukraine, Russia had made the step to take action and secure its interests in a former region of dominance.

Many of the individuals interviewed for this study candidly voiced their concerns regarding these developments; some went so far as to say that they believed the same plan was intended for Estonia down the road, especially if the actions in Ukraine went unchecked by the greater international community. While Estonia enjoys the valuable protection that being a NATO member and European Union member-state affords, its concern is rooted in the cultural resentments still harbored by its Russian minority. Issues of language, respectful integration, equality, and education - all of these point to the overarching question of whether this minority considers itself Estonian or whether its loyalty to an external homeland, such as Russia, outweighs that to its current state of residence and/or citizenship. The ROC has become increasingly known as the Kremlin's sidekick in recent years and therefore its role in recent Ukrainian events is necessary to explore. This image of close cooperation between Russian church and state is one that raises the suspicions of Estonians towards the EOC-MP in their own country; this study has already mentioned instances in which this church has mirrored the political persuasions of its mother church. These similarities do not stop at the Estonian church. The topography of the Orthodox churches in Ukraine mirror those in Estonia in a variety of ways. In the wake of the crises in Ukraine, examining how the church has acted in regards to this crisis can indicate how the actions of the Ukrainian Orthodox Church of the Moscow Patriarchate 
have an effect on the image of the ROC's conduct of external affairs and Estonia's EOCMP's own role in relation to this situation.

\subsection{Similarities}

Ukraine and Estonia both have a divided Orthodox culture. Ukraine outnumbers

Estonia with three varieties of Orthodox churches to Estonia's two: the Ukrainian Orthodox Church-Moscow Patriarchate (UOC-MP), the Ukrainian Orthodox Church-Kiev Patriarchate (UOC-KP), and the Ukrainian Orthodox Autocephalous Church (UOAC). ${ }^{201}$ The Kiev Patriarchate is home to many priests who were dismissed from their parishes in the ROC. This branch of Orthodoxy is therefore particularly known for its challenge to Moscow's authority and is often belittled by the ROC as an "assemblage of schismatics.,"202 The UOC-KP is also known for its Ukrainian nationalist fervor, a reputation that has garnered it a fair amount of government support prior to and in the wake of Euromaidan. The UOAC has member churches beyond the boundaries of the Ukrainian nation. These churches are part of the Ecumenical Patriarchate. In fact, Ukrainian Orthodoxy has a long history with the Ecumenical Patriarchate as well. Before schisms created multiple churches within the country, the sole Orthodox Church of Ukraine was not part of the Moscow Patriarchate, but rather the Ecumenical Patriarchate. It functioned as its own Metropolis of Kiev and Lesser Rus, independent from the ROC, "under the canonical jurisdiction of the Constantinopolitan Patriarchate" prior to the late $17^{\text {th }}$ century. ${ }^{203}$ It was not until 1686 that the Moscow Patriarchate annexed the church, though this action was not recognized by the Ecumenical Patriarch.

Similarities are found between the treatment of the EOC-MP and the UOC-MP in each of their respective countries. Especially as tensions with Russia mount, the native Estonian

\footnotetext{
${ }^{201}$ Ukraine also has a fairly strong Greek Catholic (or Eastern-Rite) Catholic Church as well.

${ }^{202}$ Dmitri A. Sidorov, "Orthodoxy, Difference and Scale: The Evolving Geopolitics of Russian Orthodox Church(es) in the $20^{\text {th }}$ Century" (PhD diss., University of Minnesota, 1998). "Russian Orthodox Church Sees Estonia as its 'Territory,"' Jamestown Foundation 6 (2000): 205, accessed September 17, 2014, http://www.jamestown.org/single/?tx_ttnews\%5Btt_news\%5D=22516\&tx_ttnews\%5BbackPid\%5D=214\&no cache $=1 \#$.VCQ2Lkum1ME

${ }^{\overline{20}}$ Fr. J. Buciora, "Canonical Territory of the Moscow Patriarchate," Ukrainian Orthodox Church of Canada, February 20, 1996, accessed September 25, 2014, 16, http://www.uocc.ca/pdf/theology/Canonical\%20Territory.pdf
} 
and Ukrainian population increasingly view the Moscow Patriarchate affiliated churches negatively. Just as my interviewees who were not connected with the EOC-MP referred to it as the "Russian" church or simply the "Moscow Patriarchate," similar terminology reigns in Ukraine. Those connected to the church usually just refer to their church as the Russian Orthodox Church, while opponents employ its Moscow Patriarchate descriptor more often, drawing attention to its Russian link and hierarchical dependence on Moscow. ${ }^{204}$ Since the dissolution of the Soviet Union, Ukrainians have been markedly more religious than Russians living in Ukraine, an opposite trend to the one in Estonia where members of the Russian minority are more religious than ethnic Estonians. The rise in religiosity among ethnic Ukrainians following the USSR's collapse can be perceived as an expression of personal rebellion against the former Soviet occupiers and the Russian state that took its place which clearly hoped to retain or regain influence in the region. The same can be said for the rise in Lutheran and Orthodox believers directly preceding and following the independence of Estonia, though these numbers declined once their identity was no longer so threatened. The popularity of the Ukrainian language within the Ukrainian churches' publications and sermons, as opposed to Russian, also lent itself to the more nationalisticbased connection between religiosity and ethnicity. ${ }^{205}$ Specific regional and ethnic groups have been affiliated with particular churches. In the east, Moscow-affiliated churches dominate, while Greek Catholics are most populous in the west and the Kiev Patriarchate's churches are strongly featured in the central regions of the country. ${ }^{206}$ Estonia's largest Orthodox communities coincide with its largest Russian populations, which are also located in the east, closer to the shared border.

Ukraine and Estonia also share a similar status in the eyes of Russia. As former republics of the Soviet Union, they remain within Russia's perceived sphere of influence even to this day. The ROC straddles a similar line as the Russian state with which it is affiliated. Though it recognizes the independence of both the Estonian and Ukrainian

\footnotetext{
${ }^{204}$ Sidorov, "Orthodoxy, Difference and Scale: The Evolving Geopolitics of Russian Orthodox Church(es) in the $20^{\text {th }}$ Century."

${ }^{205}$ Gretchen Krudson Gee, "Geography, Nationality, and Religion in Ukraine: A Research Note," Journal for the Scientific Study of Religion 34 (1995): 386, 389.

${ }^{206}$ Sidorov, "Orthodoxy, Difference and Scale: The Evolving Geopolitics of Russian Orthodox Church(es) in the $20^{\text {th }}$ Century."
} 
states, both the ROC and the Russian Federation prove incapable of truly letting these countries depart from their grasp, preferring to keep them in their orbit politically, economically, and culturally. According to Father J. Buciora, "It is puzzling to observe that the government of the Russian Federation indisputably recognizes the independence of Ukraine and Estonia, while the Moscow Patriarchate refuses even to consider the possibility of giving complete independence-autocephaly to the local Churches of those countries. ${ }^{207}$ Regarding Ukraine, the country is seen as an even more apt extension of Russian influence due to its closer alignment with a pan-Slavic perspective in the Orthodox Church. The Moscow Patriarchate's understanding of its canonical territory rests on an understanding of transnational unity through this shared Slavic heritage, oftentimes relying heavily on the historically Soviet territorial borders. In fact, the Russian Union of Orthodox Citizens claim that the "boundaries of Rus extend as far as the boundaries of the Russian Orthodox Church," a philosophy that lays claim to a territory that looks suspiciously like the former USSR and speaks to an imperialistic mentality. ${ }^{208}$ The borders of the ROC's jurisdiction are seemingly capable of expanding with its successful proselytization with which Russian culture goes hand-in-hand with all that the ROC claims is then by default "Russian" in character. In the case of Estonia and Ukraine, this is particularly evident. The Church is the strongest vessel in which the old Empire is preserved, eager to hold onto the local churches as if they are political assets that must be strategically managed rather than ecclesiastically served.

\subsection{The Current Situation}

The situation for the Orthodox churches in Ukraine had been tumultuous prior to Euromaidan. At the same time that Patriarch Bartholomew was visiting Estonia in late October of 2000, much to the disapproval of the Moscow Patriarchate, the Jamestown Foundation was proposing the possibility of the EAOC's break with the Russian see as a motivator and confidence-builder for the UOC-KP. The more western-leaning of the Orthodox churches in Ukraine, the UOC-KP would give nod to Bartholomew's leadership

\footnotetext{
${ }^{207}$ Buciora, "Canonical Territory of the Moscow Patriarchate," 8.

${ }^{208}$ Ibid, 3.
} 
in this competition between the two patriarchates if it were to align itself with the Ecumenical Patriarchate, while also shutting off a valve of Russian influence into this large Ukrainian church.

Fast-forward to Maidan when priests of all denominations took to the streets in cassocks, bearing crucifixes and icons, and saying prayers between protestors and riot police for peace and safety to prevail. The ecumenical nature of this event was widely reported. The UOC-KP was noted as being particularly active, considering its history of being more politically favorable towards the West than towards Russia, but clergy and laity from all Orthodox branches, as well as Protestant denominations and other faith communities, were present on the barricades and working in the aid stations. Though active on the ground praying for peace, the leadership of the UOC-MP managed its political statements shrewdly. Its representatives opted not to make pro-Maidan statements, but did address their disapproval of a divided Ukraine in letters to Putin and Patriarch Kirill. ${ }^{209}$ They were also signatories to documents drawn up by the All-Ukrainian Church Council calling for peace and the support of an independent and democratic Ukrainian state.

Though less vocal than some churches throughout the clash, the UOC-MP has shared in the call of all churches in Ukraine for an independent, democratic, and undivided Ukraine. ${ }^{210}$

The ROC's Patriarch Kirill has faced the same difficulty as the UOC-MP in choosing where he falls on the spectrum of support for Ukraine's fight. Orthodoxy has been drawn into the fray, partially because of the public intervention of various Orthodox clergy as well as the deaths or capture of priests in the escalating, continued violence. ${ }^{211}$ The ROC Patriarch both stresses the need to abstain from violence while also reiterating Ukraine's place in a "Russian world/Russky mir," a term indicating Russian-Ukrainian cultural brotherhood and deeply shared civilizational heritage that Russia has taken to stressing

\footnotetext{
${ }^{209}$ Roman Lunkin, “The Ukrainian Revolution and Christian Churches," East-West Church \& Ministry Report, Summer 2004, 2.

${ }^{210}$ Ibid, 4.

${ }^{211}$ Linda Kinstler, "Russia's Meddling Might Backfire With an Empowered, Unified Ukrainian Church,” New Republic, July 16, 2014, accessed September 22, 2014, http:/www.newrepublic.com/article/118718/ukraines-orthodox-church-might-unite-severing-russian-ties
} 
heavily with its Slavic neighbors in recent years. ${ }^{212}$ Ukraine holds a particularly important status in the Russian and Orthodox world since Kiev is the location of the baptism of Rus, from which Orthodoxy spread and grew. Kirill's history of toeing the Kremlin line becomes complicated in the instance of Ukraine; too much support for Putin will undoubtedly evoke a mutiny among the multitude of believers in Ukraine while too little outcry against Ukrainian nationalism could degrade the ROC's useful status in the eyes of the Kremlin.

Particularly frightening for the ROC is the chance that not only could it lose membership in Ukraine due to the conflict between the two nations, but the Ecumenical Patriarchate could use this situation to its advantage. In March, Andrei Zubov speculated that Constantinople could choose to recognize a Ukrainian church, either assuming the Kiev Patriarchate into its canonical jurisdiction or taking in a Ukrainian church that unites the various Orthodox churches under one title and abandons any relationship with Moscow. ${ }^{213}$ Of the ROC's canonical territory, over $50 \%$ of its parishes are located in Ukraine. The number of parishes under the ROC in Ukraine is even greater than those in Russia itself. If the ROC were to lose the UOC-MP, it would decrease the Church's size to one smaller than Constantinople's. ${ }^{214}$ A decrease of this size would be a serious blow to the ROC's international prestige and crippling for its central narrative of Moscow as the "Third Rome." The crisis in Ukraine also threatens the ROC's domestic reputation in Russia as well. Alexei Malashenko, a religion specialist at the Carnegie Moscow Center, remarked that "the Russian Orthodox Church risks gradually losing Ukraine if it just goes on repeating...the Kremlin line; it risks becoming only a national church of Russia. If Kirill loses out in Ukraine, he also becomes less attractive to the Kremlin.,"215

\footnotetext{
${ }^{212}$ Sophia Kishkovsky, "Ukrainian crisis may split Russian Orthodox Church," Religion News Service, March 14, 2014, accessed September 22, 2014, http://www.religionnews.com/2014/03/14/ukrainian-crisis-maysplit-russian-orthodox-church/

${ }^{213}$ Ibid. The UOC-MP has actually participated in talks with the other Orthodox churches, entertaining the idea of a single, fully unified Ukrainian Orthodox church. However, it's quite unlikely that such a unification would occur, especially as long as the UOC-KP is headed by Filaret, a priest that the ROC excommunicated and would be loathe to negotiate and compromise with.

${ }^{214}$ Buciora, "Canonical Territory of the Moscow Patriarchate," 11.

${ }^{215}$ Mark R. Elliott, "The Impact of the Ukrainian Crisis on Religious Life in Ukraine and Russia," East-West Church \& Ministry Report, Summer 2004, 8.
} 


\subsection{What Does This Mean for Estonia and the Country's Russian Minority?}

First, Ukraine's multiple Orthodox churches make its situation applicable to Estonia. In both countries, this divided Orthodox environment generates a competitive atmosphere and solicits from the ROC an increased concern in maintaining its hold and influence so as not to lose ground in favor of another church. Its main rival in Ukraine and Estonia, the Ecumenical Patriarchate, factors into each situation, its very presence threatening ROC dominance in the region. United Orthodox churches or simply a separation from the Moscow Patriarchate in either country would wound the ROC's authority domestically, regionally, and internationally. ${ }^{216}$ While the situation in Estonia certainly has its fair share of drama, it is in no way as volatile as what continues to unfold in Ukraine. Estonia is a more stable state and though the Russian minority has had clashes with the Estonian majority in the past (ie: the Bronze Soldier conflict), the riots in Kiev inspired no such movements among the Russian minority in Estonia. Instead, voices of Russians in Estonia have been published stating the opposite. If tested with their own referendum, many claim that they would pick Estonia as their homeland, a homeland that offers them much more opportunity than Russia can. ${ }^{217}$

However, articles and speeches to this effect do not quell the fears of most Estonians. As Russia tries to redraw the lines of Europe's map, a shift in Orthodox alliances in Ukraine would undoubtedly redraw lines on the map of Orthodoxy in Europe as well. The loss of the ROC's power in Ukraine could translate into a tighter grasp on the other Orthodox churches that they possess beyond their Russian borders. The EOC-MP has no reason at present to break or consider breaking with the ROC, making improbable any talks of Orthodox unification in Estonia. It is the good relations with its affiliated church that the

\footnotetext{
${ }^{216}$ Granted, the loss of Ukraine would be more detrimental than the loss of Estonia.

${ }^{217}$ Tom Balmforth, "Russians of Narva Not Seeking 'Liberation' By Moscow," Radio Free Europe, April 4, 2014, accessed September 30, 2014, http:/www.rferl.org/content/russia-estonia-not-crimea/25321328.html. Katja Koort, "The Russians of Estonia: Twenty Years After,” World Affairs Journal, July/August 2014, accessed September 30, 2014, http:/www.worldaffairsjournal.org/article/russians-estonia-twenty-years-after.
} 
ROC would most try to capitalize on and strengthen in order to recuperate any loses suffered elsewhere in Eastern Europe. Moreover, a threatened church may support or initiate decisions to throw more effort into propaganda-saturated media, cultural programs, and Russia-friendly political initiatives within Estonia in order to cultivate a stronger base of Russian support.

The mounting political tension and unresolved violence in Ukraine has already increased the political ardor of Russians and Estonians alike. A greater level of politicization may increase the desire of Russians to band together on the basis of their ethnicity. A key way to do so is through the EOC-MP. As Orthodoxy remains a central component to watch in the unfolding of the Ukrainian conflict, it invites members of other local Orthodox churches throughout the region, both subordinated to the ROC and not, to think about how they consider themselves as Orthodox, especially as Russian-speaking Orthodox. From my own observations in Estonia, it is possible to see how this classification is already beginning to take place. An EAOC clergyman who works as a chaplain in the Estonian Defense League spoke with me briefly about the events unfolding in Ukraine as we departed his church after our interview. He echoed similar views that had been peppering international media at the time, as Estonian leaders reiterated to the world an adamant "I told you so" as Russia dared to seize Crimea. In the face of this conflict, he seemed exceedingly proud to be Estonian, particularly as a leader of the Estonian Apostolic Orthodox Church. On the other hand, when listening to clergy from the EOC-MP, I noticed a persistent defensiveness. They were constantly defending their language, culture, ethnic heritage, their mother church, and even the Russian nation itself. I believe this defensiveness is an initial product of Estonia's long-time steely treatment of Russianspeakers, which has now been enhanced by the exponential hostility that Russia and Russians are receiving in light of the events occurring in Ukraine.

Though the criticism of Russia's actions is highly warranted, the effect that it has on Russian minorities abroad could push them closer to institutions that represent Russian identity in a culturally positive way. A primary example of this would be the Church. Just as Estonia calls upon the world to watch the events in Ukraine closely in fear that such 
attempts will be made against their borders, so too should the parallels between the Orthodox churches in Ukraine and Estonia be observed and evaluated. 


\section{Conclusion}

Estonia's Russian minority has been a group around which debate and tension have swirled for decades. Typically, minority issues in Estonia have concentrated on education, language, and citizenship policy. However, this thesis sought to discern whether religion, particularly Orthodoxy, also had a role as a platform on which a minority could build community and rally behind a shared identity. Despite the small Baltic state's popular image as an overwhelmingly non-religious country, my research indicates that the Orthodox churches do indeed serve to foster community and a sense of identity, and not necessarily just for those who actively take part in their liturgies and programs. Following the trends of polls in Russia, the numbers of those who identify with Orthodoxy in Estonia outweigh those who are actually active, showing that the same principle of belonging plays a significant role in identity, regardless of belief.

By examining how the Orthodox churches facilitate or hinder integration, it appears that though the main debates over integration policy can also be found within the churches, the EOC-MP does not necessarily help towards meeting the end goals of that policy. The issue of language within the church is the foremost reason. Language skills play an essential role in acquiring citizenship and melding with Estonian society. The EOC-MP primarily conducts its services, communications, and programs in Russian. Considering that its followers are mainly Russian speakers, this is understandable. However, the failure of the church hierarchy in Estonia to set standards for integrative measures and increased involvement that goes beyond its service to the minority population in the end promotes complacency regarding an issue that the Estonian political leadership sees as one of high priority and urgency. The insular nature of Orthodoxy, as the liturgy-centered community that it is, has the potential to contribute to reluctance by members to reach out beyond the Russian ethnic community. As all sources, surveys, and interviewees made sure to note, the composition of the two Orthodox churches in Estonia is by no means homogeneous.

However, the presence of Estonians in the EOC-MP and Russians in the EAOC is primarily dictated by necessity - which parish serves in their locale - and such crossover is assumed to be in the minority by experts, in the absence of detailed ethnic surveys of each church's membership. 
In interviews, individuals connected with the EOC-MP emphasized how long Orthodoxy had been present in Estonia and the positive and powerful historical role that it had played over the centuries throughout Central and Eastern Europe. These numerous references not only indicate the pride they have in their faith's longevity, but the power of religion to unite people through a collective cultural heritage over time, a true lineage of belief. Herveiu-Leger's concept of religion as a chain of memory is strongly present in the EOC-MP faith community. There does not appear to be a sizeable or strong niche community created around the churches, due to the high degree of inactivity among members. What the church and faith do give to those who claim them, however, is a sense of lineage, continuity, and cultural inheritance. Religion is a conduit of continuity and Orthodoxy, especially for those who claim it but do not live it, is often a marker of one's Russianness. These four factors form a relationship of mutual reinforcement which proves that religion, though perhaps not the centerpiece of minority identity, is an important contributor worth taking into account.

The mutual reinforcement of religion and ethnicity found in this specific case of Russian Orthodoxy in turn makes the avoidance of the political impossible. The ROC's own political involvement spills over Russia's borders. Its growing concerns for Ukraine's potential effect on its international standings and its continuing competition with the Ecumenical Patriarchate keep Estonia's EOC-MP in a position worthy of continued observation. A ROC in a precarious position could view its position in Estonia as even more valuable in maintaining its relationship with the Kremlin. The visits of the ROC officials, ceremonies celebrating new churches, and Patriarch Kirill's impassioned defense of the russky mir all speak to the fact that church and politics do indeed overlap.

This study sought to see how important religion was in the construction of minority identity and whether it aided or detracted from national integration aims. The case of Estonia shows that though religion is not as important to these issues as are language and education, it is an arena in which all major integration issues and conflicts of minority identity intersect in varying degrees. While Estonia's unique dynamics do not lend as much significance to religion as in other countries, such as the United States or even Russia itself, the churches still have the potential to become greater hubs of gathering and community, 
especially in the absence or inaccessibility of others. Estonia would benefit from a resolution of the property dispute that still lingers between the two Orthodox churches as this persistent conflict preserves the divide between them and encourages ethnic-based judgments from religious and non-religious alike. This conflict is also a choice candidate to be used by divisive forces to their own advantage, an example in which Russians and their supporters could point to the Estonian state and the EAOC as prejudiced and pitted against this minority, regardless of the legality of the issues. A negotiated solution to this standoff has the potential to create greater stability, as well as mutual respect and trust, between Estonians and Russians, which would only positively impact the Estonian state to which they both belong. 


\section{Bibliography}

\section{$\underline{\text { Primary Sources }}$}

Balmforth, Tom. "Russians of Narva Not Seeking 'Liberation' By Moscow." Radio Free Europe, April 4, 2014. Accessed September 30, 2014, http://www.rferl.org/content/russia-estonia-not-crimea/25321328.html.

"Baltics continue discussions to counter Russian propaganda TV." The Baltic Times, April 21, 2014. Accessed September 27, 2014. http://www.baltictimes.com/news/articles/34743/\#.VDWQ0EsmdMF

Basic Schools and Upper Secondary Schools Act, 2010. https://www.riigiteataja.ee/en/eli/530102013042/consolide

Bennetts, Marc. "In Putin's Russia, little separation between church and state." Washington Times, August 13, 2012. Accessed August 28, 2014, http://www.washingtontimes.com/news/2012/aug/13/putin-russia-little-separationchurch-state/?page=all

Concept of the Foreign Policy of the Russian Federation. Accessed August 2, 2014. http://www.mid.ru/brp_4.nsf/0/76389FEC168189ED44257B2E0039B16D

Constitution of the Republic of Estonia. Accessed August 7, 2014. http://www.president.ee/en/republic-of-estonia/the-constitution/

Department for External Church Relations of the Moscow Patriarchate. "Metropolitan Hilarion: We hope the Patriarchate of Constantinople and the Estonian State will make further steps to normalize situation of the Estonian Orthodox Church of the Moscow Patriarchate.” Accessed September 9, 2014. https://mospat.ru/en/2010/11/28/news31391/.

Department for External Church Relations of the Moscow Patriarchate. "Patriarch Kirill Begins a Primatial Visit to Estonia.” June 14, 2013. Accessed September 10, 2014. https://mospat.ru/en/2013/06/14/news87460/

Ecumenical Patriarch Bartholomew. "Patriarchal and Synodical Act of 1996 Concerning the Reactivation of the Patriarchal and Synodical Tomos of 1923 Regarding the Orthodox Metropolis of Estonia" in L'Eglise Autonome Orthodoxe D'Estonie (Approche historique et nomocanonique), ed. Archim. Grigorios D. Papathomas and R.P. Matthias H. Palli (Athens: Epektasis, 2002), 67-70.

Ecumenical Patriarch Bartholomew. "Letter of Ecumenical Patriarch Bartholomew to 
Patriarch Alexy of Moscow Concerning the Orthodox in Estonia." Orthodox Church of Estonia, February 24, 1996. Accessed August 31, 2014. http://www.orthodoxa.org/GB/estonia/documentsEOC/reponseAlexis.htm.

Ecumenical Patriarch Meletios, "Tomos of 1923 on the Autonomy of the Apostolic Orthodox Church in Estonia," in L'Eglise Autonome Orthodoxe D'Estonie (Approche historique et nomocanonique), ed. Archim. Grigorios D. Papathomas and R.P. Matthias H. Palli (Athens: Epektasis, 2002), 55-58.

Eesti Kirikute Nõukogu. Tegevusaruanne. Tallinn, Estonia: 2013.

“Estonian Integration Strategy 2008-2013, Implementation Plan for 2011-2013," 1-7. http://www.kul.ee/sites/default/files/eis_implementation_plan_2011-13_en.pdf

Estonian Council of Churches. "Elust, usust ja usuelust.” Tallinn, 1995.

Estonian Council of Churches. "Elust, usust ja usuelust.” Tallinn, 2000.

Estonian Council of Churches. "Elust, usust ja usuelust.” Tallinn, 2005.

Estonian Council of Churches. "Elust, usust ja usuelust.” Tallinn, 2010.

Estonia.eu. "Russian-language schools' transition to partial Estonian-language instruction-What is happening and why?" Last modified January 13, 2013. http://estonia.eu/about-estonia/society/russian-language-schools-transition-topartial-estonian-language-instruction-what-is-happening-and-why.html

Estonia.eu. “Estonia's Return to Independence 1987-1991.” Accessed August 29, 2014, http://estonia.eu/about-estonia/history/estonias-return-to-independence19871991.html.

Estonian Public Broadcasting. "Church Monument Unveiling Attracts Thousands." September 10, 2012. Accessed September 10, 2014. http://news.err.ee/v/society/ca90d249-c858-444f-b41f-1ac2fa440103

Estonian Public Broadcasting. "Orthodox Church Canonizes 11 Estonian Martyrs.” May 17, 2012. Accessed September 22, 2014. http://news.err.ee/v/culture/07cc38314d86-40ad-be5e-ced39487b14d

Kaer, Kaisa. "Lasnamäe - the Final Frontier?" Estonian Public Broadcasting, June, 26, 2014. Accessed September 10, 2014, http://news.err.ee/v/features/b24834ad-ec9a$45 \mathrm{cf}-8 \mathrm{~b} 16-4357 \mathrm{e} 4492255$.

Kangro, Karin and Helen Mihelson. "Centre Party popularity towering in Tallinn." 
Postimees in English, August 8, 2013. Accessed September 10, 2014. http://news.postimees.ee/1318780/centre-party-popularity-towering-in-tallinn.

Kinstler, Linda. "Russia's Meddling Might Backfire With an Empowered, Unified Ukrainian Church." New Republic, July 16, 2014. Accessed September 22, 2014. http://www.newrepublic.com/article/118718/ukraines-orthodox-church-might-unitesevering-russian-ties

Kishkovsky, Sophia. "Ukrainian crisis may split Russian Orthodox Church.” Religion News Service, March 14, 2014. Accessed September 22, 2014.

http://www.religionnews.com/2014/03/14/ukrainian-crisis-may-split-russianorthodox-church/

Kornilii, Metropolitan of Tallinn and All Estonia. "Statement to the Media About the Events of April 26-29 2007.” May 4, 2007. Accessed September 4, 2014. http://www.pravmir.com/article_218.html.

Kort, Katja. "The Russians of Estonia: Twenty Years Later.” World Affairs Journal, July/August 2014. Accessed August 2, 2014.

http://www.worldaffairsjournal.org/article/russians-estonia-twenty-years-after

Kosachev, Konstantin. "Russia must defend interests of compatriots abroad." Valdai, March 3, 2013. Accessed October 20, 2013. http://valdaiclub.com/politics/56220.html.

"Language inquisition: Estonia gets tough on Russian speakers." Russia Today, December 1 2011. Accessed September 22, 2014. http://rt.com/news/estoniarussian-language-ban-635/.

Levy, Clifford J. "Estonia Raises Its Pencils to Erase Russian.” New York Times, June 7 2010. Accessed September 22, 2014. http://www.nytimes.com/2010/06/08/world/europe/08estonia.html.

Linkgreim, Inga-Gretel. "Metropoliit Kornelius tähistab 85. Sünnipäeva.” ERR, June 19, 2009. Accessed September 18, 2014. http://uudised.err.ee/v/vr/kultuur/9c01f0e73268-42b4-8df0-bad84268af76.

“Metropoliit Korneliuse 80. Sünnipäev." ERR, June 19, 2004. Accessed September 18, 2014. http://uudised.err.ee/v/d5858df8-df06-47de-bb32-bdbf6589fd3a

On Freedom of Conscience and Religious Associations. October 1, 1997. http://www2.stetson.edu/ psteeves/relnews/freedomofconscienceeng.html

Paraskevopoulos, Theodore. "Ethnophyletism." Sermon, Ancient Faith Radio, December 
13, 2010. http://www.ancientfaith.com/podcasts/isermon/ethnophyletism.

Ringvee, Ringo. "Is Estonia really the least religious country in the world?" The

Guardian, September 16, 2011. Accessed August 25, 2014.

http://www.theguardian.com/commentisfree/belief/2011/sep/16/estonia-leastreligious-country-world.

Russkiy Mir Foundation. "Monument to Patriarch Alexy II Unveiled in Tallinn."

September 10, 2012. Accessed September 10, 2014.

http://www.russkiymir.ru/en/news/129780/.

"Russian Orthodox Church Sees Estonia as its 'Territory,"” Jamestown Foundation 6 (2000)

http://www.jamestown.org/single/?tx_ttnews\%5Btt_news\%5D=22516\&tx_ttnews\% 5BbackPid\%5D=214\&no_cache=1\#.VCQ2Lkum1ME

Springe, Inga, Sallija Benfelde, and Miks Salu. "The Unknown Oligarch.” Re:Baltica, April 11, 2012. Accessed September 17, 2014.

http://www.rebaltica.lv/en/investigations/money_from_russia/a/608/moscow's_spin _machine_in_estonia_.html

Statistics Estonia, 2000 census http://www.stat.ee/population-census

Statistics Estonia, 2011 census http://www.stat.ee/population-census

Teesalu, Ingrid. "Savisaar: Lasnamäe Orthodox Church Will Be Ready By Deadline." Estonian Public Broadcasting, June 27, 2012. Accessed September 11, 2014. http://news.err.ee/v/varia/9bcac2c0-42cc-46d8-a52a-0e4030775f16

Tubalkain-Trell, Marge. "Populists coming back." The Baltic Times, April 9, 2008. Accessed September 10, 2014.

http://www.baltictimes.com/news/articles/20186/\#.VBcXeEum1ME

Vedler, Sulev. "Moscow's Spin Machine in Estonia." RE:Baltica, March 20, 2012. Accessed September 17, 2014.

http://www.rebaltica.lv/en/investigations/money_from_russia/a/608/moscow's_spin _machine_in_estonia_html

Zvejniece, Laura."A Re:Baltica Investigation: the first cross-border investigation of Russia's soft power in the Baltics.” Re:Baltica,. Accessed September 17, 2014. http://www.rebaltica.lv/en/investigations/money_from_russia

Interviews

Hirvoja, Toomas. Interview by author, June 6, 2014. 
Jõks, Eerik. Interview by author, June 2, 2014.

Prekup, Igor. Interview by author, June 4, 2014.

Ringvee, Ringo. interview by author, June 3, 2014.

Rothmets, Priit. Interview by author, June 7, 2014.

Sarapik, Aivar. Interview by author, June 3, 2014.

$\underline{\text { Secondary Sources }}$

Agadjanian, Alexander. "The Search for Privacy and the Return of a Grand Narrative Religion in a Post-Communist Society.” Social Compass 53 (2006): 169-184.

Alfeyev, Bishop Hilarion "One City, One Bishop, One Church-Part I."

OrthodoxyToday.org. January 27, 2006, Accessed November 28, 2014. http://www.orthodoxytoday.org/articles6/HilarionOneBishop.php.

Anderson, Benedict. Imagined Communities: Reflections on the Origin and Spread of Nationalism. London: Verso, 1991.

Best, Heinrich. "History Matters: Dimensions and Determinants of National Identities among European Populations and Elites.” Europe-Asia Studies 61, 6 (2009): 921941.

“BMA Infographic,” Digital Image. Re:Baltica. Accessed September 17, 2014. http://www.rebaltica.lv/en/investigations/money_from_russia/pbk_infographic

Brubaker, Rogers. Nationalism Reframed: Nationhood and the National Question in the New Europe. Cambridge: Cambridge University Press. 1996.

Brubaker, Rogers. "Ethnicity, Race and Nationalism." Annual Review of Sociology 35 (2009): 21-42.

Brubaker, Rogers. "Migration, Membership, and the Modern Nation-State: Internal and External Dimensions of the Politics of Belonging." Journal of Interdisciplinary History 41 (2010): 61-78.

Buciora, J. "Canonical Territory of the Moscow Patriarchate." Ukrainian Orthodox Church of Canada, February 20, 1996. Accessed September 25, 2014. http://www.uocc.ca/pdf/theology/Canonical\%20Territory.pdf

Clendenin, Daniel B., ed. Eastern Orthodox Theology: A Contemporary Reader. Grand 
Rapids: Baker Books, 1995.

Davie, Grace. Religion in Britain since 1945: Believing without Belonging. Oxford: Blackwell, 1994.

Davie, Grace. "Vicarious Religion: A Methodological Challenge." In Everyday Religion: Observing Modern Religious Lives, edited by Nancy T. Ammerman, 21-35. Oxford: Oxford University Press, 2007.

Davie, Grace. Religion in Modern Europe: A Memory Mutates. Oxford: Oxford University Press, 2000.

Davie, Grace. “Is Europe an Exceptional Case?” Hedgehog Review (2006): 23-34.

Department for External Church Relations of the Moscow Patriarchate. "The Estonian Church: Background Information. ” Accessed September 1, 2014. http://www2.stetson.edu/ psteeves/relnews/estonia2502.html

Ducker, Chris. "Believing in Grace Davie: what does she bring to an understanding of mission in Europe?," Encounters Mission Journal 36 (2011): 1-12.

Elliott, Mark R. "The Impact of the Ukrainian Crisis on Religious Life in Ukraine and Russia.” East-West Church \& Ministry Report, Summer 2004, 6-16.

Fajfer, Lukasz and Sebastian Rimestad. "The Patriarchates of Constantinople and Moscow in a global age: a comparison." International Journal for the Study of the Christian Church 10 (2010): 211-227.

Feldman, Gregory. "Culture, State and Security in Europe: The Case of Citizenship and Integration Policy in Estonia." American Ethnologist 32, 4 (2005): 676-694.

Filatov, Sergey. "Orthodoxy in Russia: Post-atheist Faith." Studies in World Christianity 14, 3 (2008): 187-202.

Garrard, John and Carol Garrard. Russian Orthodoxy Resurgent: Faith and Power in the New Russia. Princeton: Princeton University Press, 2008.

Gee, Gretchen Krudson. "Geography, Nationality, and Religion in Ukraine: A Research Note.” Journal for the Scientific Study of Religion, 34 (1995): 383-390.

Heneghan, Tom. "Russian church the absent player at pope-patriarch summit." Reuters, May 19, 2014, Accessed November 28, 2014, http://www.reuters.com/article/2014/05/19/us-pope-holyland-russiaidUSKBN0DZ13B20140519. 
Hervieu-Leger, Daniele. Religion as a Chain of Memory. Translated by Simon Lee. New Brunswick: Rutgers University Press, 2000.

Hogan-Brun, Gabrielle. "Language, education policy and transformation in Central and Eastern Europe." Comparative Education 46, 1 (2010): 3-12.

Kilp, Alar. "Lutheran and Russian Orthodox Church Buildings as Symbols of Cultural Identity in the Estonian Parliamentary Elections of 2011." Religion, State and Society 41 (2013): 312-329.

Knox, Zoe. "The Symphonic Ideal: The Moscow Patriarchate's Post-Soviet Leadership." Europe-Asia Studies 55, 4 (2003): 575-596.

Knox, Zoe. "Russian Orthodoxy, Russian Nationalism, and Patriarch Aleksii II." Nationalities Papers 33, 4 (2005): 533-545.

Krindatch, Alexey D. "Changing relationships between Religion, State and Society in Russia.” GeoJournal 67 (2006): 267-282.

Kuus, Merje. "European Integration in Identity Narratives in Estonia: A Quest for Security." Journal of Peace Research 39, 1 (2002): 91-108.

Kvale, Steiner. Doing Interviews. London: SAGE Publications, Ltd., 2007.

Laar, Mart. "The Restoration of Independence in Estonia," in Estonia: Identity and Independence. Edited by Jean-Jacques Subrenat, 225-238. Amsterdam: Rodopi, 2004.

Laitin, David D. Identity in Formation: The Russian-Speaking Populations in the Near Abroad. Ithaca: Cornell University Press, 1998.

Lauristin, Marju, Esta Kaal, Laura Kirss, Tanja Kriger, Anu Masso, Kirsti Nurmela, Kulliki, Seppel, Tiit Tammaru, Maiu Uus, Peeter Vihalemm, and Maria Jufereva. "Estonian Integration Monitoring 2011 Summary.” 2011.

Levitt, Peggy. "Redefining the Boundaries of Belonging: The Transnationalization of Religious Life," in Everyday Religion: Observing Modern Religious Lives. Edited by Nancy T. Ammerman, 103-120. Oxford: Oxford University Press, 2007.

Lossky, Vladimir. Orthodox Theology: An Introduction. Translated by Ian and Ihita Kesarcodi-Watson. Crestwood: St. Vladimir's Seminary Press, 1978.

Lunkin, Roman. "The Ukrainian Revolution and Christian Churches.” East-West Church 
\& Ministry Report, Summer 2004. 1-5.

Meyendorff, John. The Orthodox Church: Its Past and Its Role in the World Today. Translated by John Chapin. New York: Pantheon Books, 1968.

Mikecz, Robert. "Interviewing Elites: Addressing Methodological Issues.” Qualitative Inquiry 18 (2012): 482-493.

Nye Jr., Joseph S. “Soft Power.” Foreign Policy 80 (1990): 153-171.

Paert, Irina. Memory of socialism and the Russian Orthodox believers in Estonia. (Forthcoming).

Pankhurst, Jerry G. and Alar Kilp. "Religion, the Russian Nation and the State: Domestic and International Dimensions: An Introduction." Religion, State, and Society 41 (2013): 226-243.

Papkova, Irina. 'Saving the Third Rome: 'Fall of the Empire,' Byzantium and Putin's Russia in Reconciling the Irreconcilable. Edited by I. Papkova. Vienna: IWM Junior Visiting Fellows' Conferences, 2009.

Plaat, Jaanus. "Christian and Non-Christian Religiosity in Estonia in the 1990s: Comparison of Estonians and Other Ethnic Groups." Pro Ethnologia 14 (2002): 97134.

Prekup, Igor. "The Ninetieth Anniversary of the Estonian Orthodox Church (Moscow Patriarchate)." Europaica, April 3, 2008. Accessed September 1, 2014. http://orthodoxeurope.org/page/14/143.aspx\#3.

Republic of Estonia Ministry of Culture. "Cultural Diversity." Accessed September 7, 2014. http://www.kul.ee/en/activities/cultural-diversity.

Riasanovsky, Nicholas V. and Mark D. Steinberg. A History of Russia Eighth Edition. New York: Oxford University Press, 2011.

Richters, Katja. The Post-Soviet Russian Orthodox Church: Politics, Culture and Greater Russia. New York: Routledge, 2013.

Rohtmets, Priit and Ringo Ringvee. "Religious Revival and the Political Activity of Religious Communities in Estonia During the Process of Liberation and the Collapse of the Soviet Union 1985-1991." Religion, State and Society 41, 4 (2013): 355-393.

Rohtmets, Priit. "Development of the Membership of the Estonian Council of 
Churches," in History of Estonian Ecumenism. Edited by Riho Altnurme and Priit Rohtmets. Tallinn: Estonian Council of Churches, 2009: 273-309.

Saard, Riho. "Establishment of the Estonian Council of Churches," in History of Estonian Ecumenism. Edited by Riho Altnurme and Priit Rohtmets. Tallinn: Estonian Council of Churches, 2009: 240-272.

Schmemann, Serge. "Soul of Russia.” National Geographic (2009) http://ngm.nationalgeographic.com/2009/04/orthodox/schmemann-text/1

Sidorov, Dmitrii. Orthodoxy and Difference: Essays on the Geography of Russian Orthodox Church(es) in the $20^{\text {th }}$ Century. San Jose: Pickwick Publications, 2001.

Sidorov, Dmitrii A. "Orthodoxy, Difference and Scale: The Evolving Geopolitics of Russian Orthodox Church(es) in the $20^{\text {th }}$ Century." PhD diss., University of Minnesota, 1998.

Talantov, Boris. "The Moscow Patriarchate and Sergianism." Orthodox Christian Information Center, 1968. http://orthodoxinfo.com/ecumenism/cat_tal.aspx

Terry, Chris. "Estonian Centre Party (KESK).” Demsoc Europe, February 27, 2014. Accessed September10, 2014. http://europe.demsoc.org/2014/02/27/estonian-centreparty-kesk/

Trenin, Dmitry. “Orthodox Diplomacy." Carnegie Moscow Center Eurasia Outlook, 2013. Accessed October 20, 2013. http://valdaiclub.com/politics/60920.html

Verdery, Katherine. The Political Lives of Dead Bodies: Reburial and Postsocialist Change. New York: Columbia University Press, 1999.

Daniel, Wallace L. The Orthodox Church and Civil Society in Russia. College Station: Texas A\&M University Press, 2006. 
Appendix I

Interview Questions ${ }^{218}$

1. Please state your name, profession/job title, and a little bit about what you do.

2. Describe the religious environment in Estonia.

3. Could you speak about your general perceptions of the Estonian Orthodox ChurchMoscow Patriarchate and the Estonian Apostolic Orthodox Church?

4. What role does the Estonian Orthodox Church-Moscow Patriarchate play amongst the Russian minority?

5. In your opinion, is the Russian Orthodox community centered more on national/cultural identity or Christian identity?

6. In your opinion, has the Orthodox Church hindered or helped Russians' integration into Estonian society?

Interview transcripts are available upon request.

218 The questions were general guidelines. In the interviews, each question may have been asked in a different order or worded slightly differently, depending on the direction that the interview was taking. 